\title{
The structure of diatom communities constrains biogeochemical properties in surface waters of the Southern Ocean (Kerguelen Plateau)
}

\author{
Lafond Augustin ${ }^{1,}{ }^{*}$, Leblanc Karine ${ }^{1}$, Legras Justine ${ }^{1}$, Cornet Véronique ${ }^{1}$, Quéguiner Bernard ${ }^{1}$
}

${ }^{1}$ Aix-Marseille University, Université de Toulon, CNRS, IRD, MIO, UM 110, 13288, Campus de Luminy, 163 avenue de Luminy, Marseille 13288, France

* Corresponding author : Augustin Lafond, email address : augustin.lafond@gmail.com

\begin{abstract}
:
In the context of climate change, understanding the ecological processes controlling the functioning and the efficiency of the biological pump is of primary importance. Plankton community structure and speciesspecific properties are often invoked as likely to affect biogeochemistry and the export of organic and biogenic material to the ocean interior. Although a major player in this respect, diatoms are still viewed as a single functional type whose diversity is generally overlooked. Here we examine that question, building on the results achieved during the MOBYDICK expedition, which occurred in the vicinity of the Kerguelen Islands (Southern Ocean) in late summer, a time window corresponding to the demise of the annually recurrent phytoplankton blooms already known to be controlled by iron availability. The Si/C/N stoichiometry of the particulate matter was studied in conjunction with the different diatom community structures, their physiological states, as well as their species-specific carbon contents and silicification degrees. Our results show that diatoms outside the iron-fertilized plateau were more heavily silicified, due to the combined effects of both taxonomic composition of the resident community and a direct physiological response to iron stress, resulting in higher Si:C elemental ratios in diatoms as well as in the bulk particulate matter. Despite low silicic acid concentrations, large chains of weakly silicified Corethron inerme were able to grow in the upper mixed layer above the plateau, while in adjacent high nutrient low chlorophyll (HNLC) waters, communities were dominated by Fragilariopsis spp., Cylindrotheca closterium and the centric genera Actinocyclus/Thalassiosira spp. Depth was also an important factor shaping diatom communities, with the presence of a deep and inactive assemblage located within the pycnocline gradient, both on- and off-plateau, which likely resulted from the differential sinking and accumulation of species previously grown at the surface. In HNLC waters, below the mixed layer, detrital frustules of the heavily silicified species Fragilariopsis kerguelensis carried mostly $\mathrm{Si}$, while above the plateau, Eucampia antarctica and Chaetoceros spp. (resting spores and vegetative stages) were efficient vectors of both $\mathrm{Si}$ and $C$ to the deeper layers. Our study shows that the stoichiometry of the biological pump cannot be considered solely as a simple response to a single limiting factor (here iron) highlighting the importance of a species-centered approach in order to finely resolve biogeochemical fluxes and improve our understanding of the biological pump.
\end{abstract}




\section{Highlights}

- A distinct diatom community was growing despite low $\left[\mathrm{Si}(\mathrm{OH})_{4}\right]$ above the Fe-fertilized plateau. $\rightarrow$ A deep and inactive diatom community was systematically found within the pycnocline gradient. In HNLC waters, diatoms were more heavily silicified and exhibited higher Si:C ratios. In HNLC waters, detrital frustules of Fragilariopsis kerguelensis carried mostly Si below the ML. Above the plateau, Chaetoceros spp. vegetative cells and spores carried Si and C below the ML.

Keywords : Southern Ocean, Kerguelen Plateau, Diatoms, Community structure, Biological pump 


\section{Introduction}

The Southern Ocean (SO) is a major sink for anthropogenic $\mathrm{CO}_{2}$ and plays an important role in redistributing heat and nutrients at the global scale (Sarmiento et al., 2004; Sallée et al., 2012; Takahashi et al., 2012; Frölicher et al., 2015). It is also the largest High Nutrient Low Chlorophyll (HNLC) area, and as such its surface waters are characterized by low phytoplankton biomass, despite elevated macronutrient corzentrations. This paradox has been solved in the early 1990s when dissolved iron was idr...+itıd as a potentially strong limiting factor for primary production (Martin, 1990; "Thr 'run. Hypothesis"). In contrast to HNLC waters, highly productive, naturally iron fertilis sd vivoms are observed in discrete areas of the SO, located downstream of island syste ns $\leq 1$ ch as the Kerguelen Plateau (Blain et al., 2007), Crozet Islands (Pollard et al., 2009) anci Souin Georgia (Whitehouse et al., 1996; Korb and Whitehouse, 2004; Korb et al., 20)8; '.1 these so called "natural laboratories", blooms are dominated by siliceous $d^{\prime}$ to' $a s$, and $C$ export is 2-3 times higher than in surrounding Fe-limited areas (Morris et al., <007; Savoye et al., 2008; Planchon et al., 2015) which are typically dominated by ar cc:rouhic nanoplankton (Kopczyńska et al., 1998; Uitz et al., 2009; Lasbleiz et al., 2016). Un? to their large sizes, and the ballasting effect of their frustule, diatoms are classicali, considered as efficient vector of C export (Buesseler, 1998; Armstrong et al., 2002). T'rol ghout the productive season, they progressively consume $\mathrm{Si}(\mathrm{OH})_{4}$ which becomss : mit ng in summer, leading to the termination of the bloom (Boyd, 2002; Leblanc et al., 2005 Nelson et al., 2001; Franck et al., 2000).

However, the discovery of High Biomass Low Export ecosystems dominated by diatoms (Lam and Bishop, 2007), and later on, the recurrent observation of an inverse relationship between primary production and export efficiency in the Southern Ocean challenged our understanding of the carbon biological pump (Maiti et al., 2013; Henson et al., 2019). Plankton community structure and species-specific properties can strongly influence the transfer of biogenic minerals (e.g. Si) and organic matter (e.g. C, N etc.) to the ocean interior (Salter et al., 2012; Assmy et al., 2013; Quéguiner, 2013; Rembauville et al., 2015b, 2016; Tréguer et al., 2018; Arteaga et al., 2019). This is particularly true for diatoms which exhibit a 
wide range of size and biovolumes (Leblanc et al., 2012), as well as an incredible morphological diversity, with certain shape facilitating the formation of rapidly sinking aggregates (Alldredge and Gotschalk, 1989; Alldredge and Jackson, 1995; Jackson et al., 2005; Burd and Jackson, 2009; Assmy et al., 2013). Cellular Si:C quota, a key parameter controlling frustule density and sinking rate, varies widely among diatom species (Durkin et al., 2012), in addition of being influenced by environmental parameters such as iron availability (Hutchins and Bruland, 1998; Takeda, 1998). Indeed, numerous iron-fertilization experiments observed higher $\mathrm{Si}: \mathrm{C}$ and $\mathrm{Si}: \mathrm{N}$ ratios in diatoms growing under iron-stress, which seemed to indicate the development of more heavily silicified frustules, although it has also be linked to a reduction in cellular organic matter c נrisenis (Takeda, 1998; Twining et al., 2004; Hoffmann et al., 2007; Marchetti and Cassar, ¿vig; Baines et al., 2011). Within a given species, life stages such as auxospores and resi $\mathrm{ng}$ torms can undergo considerable morphological and physiological changes compa: $d$ o vegetative stages, e.g. heavily silicified resting spores are resistant to grazing ( $(\cdots \cdots$ vata and Tsuda, 2005) and can contain up to 10 times more carbon (Doucette and Fr.xeı, 1983; Kuwata et al., 1993), which make

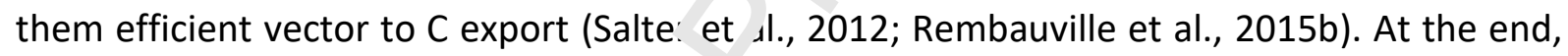
mortality pathways (apoptosis, vir' lysis, parasite infection, grazing etc.) will further influence export modes and their ef ,-iency (Kagami et al., 2007; Sherr and Sherr, 2007; Durkin et al., 2016; Kranzler et al, ¿i19). Despite this apparent complexity, the link between species diversity and particles $t$.'port is often overlooked. To date, two studies attempted to further refine the diatom fur -ti nnal group intro two subgroups occupying different niches in the water column: C-: $n k$, r/r, roup 1 comprise small, fast-growing lightly silicified and colonyforming diatoms that dor inate iron-fertilized areas, while Si-sinker/Group 2 are large, slow growing heavily silicified species that thrive in iron-limited areas (Assmy et al., 2013; Quéguiner, 2013).

The Kerguelen region is a good place to study the ecological processes at play in the biological pump, since the area is characterized by contrasted ecosystems differently impacted by iron. Due to its shallow bathymetry $(<700 \mathrm{~m})$ and its great meridional extension, the Kerguelen Plateau acts as a natural barrier diverting both the trajectories of the Antarctic Circumpolar Current (ACC) and the Polar Front (PF) (Park et al., 2008b; Park et al., 2014). Interactions between water masses and the plateau leads to the upward transfer 
of iron via diapycnal mixing enhanced by internal wave activity (Blain et al., 2007; Park et al., 2008a), giving an annually recurrent phytoplankton bloom from October to February (Mongin et al., 2008). Past oceanographic surveys investigated the decline and the onset of the diatom bloom (KEOPS1 and KEOPS2 cruises, respectively), by describing diatom community composition (Armand et al., 2008b; Lasbleiz et al., 2016), biogeochemical environments (Lasbleiz et al., 2014), silica production (Mosseri et al., 2008; Closset et al., 2014) and associated carbon export (Savoye et al., 2008; Planchon et al., 2015; Rembauville et al., 2015a).

In this context, the MOBYDICK cruise (Marine Ecosystem Di diversity and Dynamics of Carbon around Kerguelen: an integrated view) took place : 1 - 'opruary and March 2018, i.e. at the very end of summer to witness the demise of the iatom bloom, an event that is much less described than the spring bloom, but that none helf ss plays a crucial role in the carbon biological pump. Main objectives of MOBYDIC!. were 1) to track carbon from its initial fixation at the surface to its channeling throu $h$ Li.- food web or export into the deep ocean; and 2) provide a detailed description of the diversity at each trophic level, from microbes to micronekton. In this study, we aim ai describıng diatom diversity and the composition of the bulk particulate matter, on and o 1 . o plateau. In particular, we focused our effort on providing a comprehensive descrirtion of diatom community structures, in terms of abundances, carbon biomass, nhysiological states, and silicification activity at multiple scales, i.e. from the comı'innty level to single-cell level. The following questions are addressed: How doe, irc $n$ ir.fluence diatom community structure during the demise of the Kerguelen bloom? How $\mathrm{r}$ diatoms influence the elemental composition and stoichiometry of the particulate matter? What are the ecological vectors driving Si and C export?

\section{Methods}

\subsection{Sampling strategy}

The MOBYDICK cruise was conducted south of the Kerguelen Islands in the Indian sector of the Southern Ocean (SO), aboard the French R/V Marion Dufresne II in late austral summer (18 February-27 March 2018). In this study, coinciding with the demise of the diatom bloom, a total of four stations were investigated with repeated visits at some of them (Figure 1, 
Table 1). Two reference stations, $M 2$ (sampled thrice) and $M 4$ (sampled twice), were respectively defined for the Fe-enriched plateau and the HNLC off-plateau area. Two intermediate stations, M1 and M3 were additionally sampled, once and twice respectively. Bottom depths spanned from $520 \mathrm{~m}$ at M2 to $4730 \mathrm{~m}$ at M4 (Table 1). According to Pauthenet et al. (2018), station M3 was located within the Polar Frontal Zone (PFZ), whereas the other stations were located in the Antarctic zone (AAZ), with M1 and M4 both situated very close to the PF (Figure 1).

\subsection{Hydrology}

Seawater collection and vertical profiles of water column prop rties were made from an array of 24 bottles (12 L) mounted on a rosette equipped wi ${ }^{\text {in }}$ d Seabird SBE-911 plus CTD unit, which also included a fluorometer for detection o ${ }^{-r}$.orophyll $a(\mathrm{Chl} a)$, and a PAR (photosynthetically available radiation) sensor (LI-C JR , nstrument). The mixed layer depth (MLD) was defined as the depth where the potentia' der.-ity equaled the potential density at $10 \mathrm{~m}+0.03 \mathrm{~kg} \mathrm{~m}^{-3}$ (de Boyer Montégut et $\partial^{\prime}$., - or 4). The depth of the euphotic zone (Ze) was defined as the depth where $1 \% \mathrm{r} \mathrm{t}$ e surface irradiance remained. Discrete water samples were collected at 11 depths down, $500 \mathrm{~m}$ at the plateau station M2 and down to $1000 \mathrm{~m}$ at the other stations.

\subsection{Inorganic nutrients}

Samples were collected in $12 \mathrm{bL}$ HDPE bottles directly from the Niskin bottles. The samples were then filtered on $0 . \mathrm{C}^{\mathrm{r}} \mathrm{m}$ cellulose acetate filter and preserved with $100 \mu \mathrm{L} \mathrm{HgCl}\left(4 \mathrm{~g} \mathrm{~L}^{-}\right.$ ${ }^{1}$ ) in $20 \mathrm{~mL}$ vials, which vere then stored in the dark at room temperature until analysis in the laboratory. For $\mathrm{NO}_{3}, \mathrm{PO}_{4}{ }^{3-}$, and $\mathrm{H}_{4} \mathrm{SiO}_{4}$, the preserved samples were analyzed in the laboratory with a segmented flow analyzer (Skalar) equipped with colorimetric detection using the classical methods described in Aminot and Kérouel (2007). The accuracy of the methods was assessed using reference material (Certipur, Merck). The precisions were in the range of 1-4 \%, and the limit of detection was $0.02 \mu \mathrm{M}$ for $\mathrm{NO}_{3}{ }^{-}, 0.03 \mu \mathrm{M}$ for $\mathrm{PO}_{4}{ }^{3-}$ and 0.05 $\mu \mathrm{M}$ for $\mathrm{H}_{4} \mathrm{SiO}_{4}$ (Blain et al., 2015).

\subsection{Pigments}

For pigment measurements, $2.32 \mathrm{~L}$ water samples were filtered onto Whatman GF/F filters and stored in liquid nitrogen until analysis. Back at the laboratory, filters were extracted in 
$100 \%$ methanol, disrupted by sonication, and clarified by filtration (GF/F Whatman) after 2 h. Samples were analyzed within $24 \mathrm{~h}$ using High Performance Liquid Chromatography on an Agilent Technologies HPLC 1200 system quipped with a diode array detector following Ras et al. (2008).

\subsection{Particulate organic carbon (POC) and nitrogen (PON)}

From the rosette sampling, $4 \mathrm{~L}$ of seawater were filtered onto precalcinated $\left(450^{\circ} \mathrm{C}, 24 \mathrm{~h}\right) 25$ $\mathrm{mm}$ Whatman GF/F filters. Filters were then dried in an oven $\left(40^{\circ} \mathrm{C}, 24 \mathrm{~h}\right)$ and stored in a glass vial until analysis. After fumigation with pure $\mathrm{HCl}(10 \mathrm{~h})$ to dissolve remaining inorganic carbon, analysis of $\mathrm{C}$ and $\mathrm{N}$ was made with a $\mathrm{CHN}$ elementa. analyzer calibrated with acetanilide (Rembauville et al., 2016).

\subsection{Biogenic silica stock (BSi)}

Between 1.5 and $2 \mathrm{~L}$ Niskin samples were filtered thro . $\mathrm{n} 0.4 \mu \mathrm{m}$ Nucleopore polycarbonate filters. Filters were then rinsed with $0.2 \mu \mathrm{m}$ fil $\mathrm{e}^{r} \mathrm{e}^{\prime}$ ' seawater, folded in quarters, placed in Petri dishes and dried overnight at $60^{\circ} \mathrm{\sim}$. . $_{1}{ }^{+}$ers were kept at room temperature until analyses at the laboratory. The extracı $\cdot n$ of silicon from biogenic particle phase was performed following the Ragueneau et a' (2005) triple $\mathrm{NaOH} / \mathrm{HF}$ extraction procedure.

\subsection{Plankton counting}

Prior to counting, plankton c'ive- -ity was investigated in few representative samples using a Phenom Pro scanning elertru microscope (SEM) in order to resolve the taxonomic list of species at the best pu: sin! - ievel for the study area. For SEM analysis, water samples were filtered $(50 \mathrm{~mL})$ onto $r$ lycarbonate filters $(0.8 \mu \mathrm{m}$ pore size, Whatman), and stored in Millipore Petri Slides at room temperature with no further treatments. Pictures were taken at magnification up to $\times 25,000$.

For plankton counting, seawater samples collected from the same casts and bottles as particulate Si samples were preserved in $250 \mathrm{~mL}$ amber glass bottles with $1.6 \mathrm{~mL}$ acidified Lugol solution before being stored in the dark at $4^{\circ} \mathrm{C}$ until analysis. For each station and visit, 8 samples from the surface down to $250 \mathrm{~m}$ were counted, giving a total number of 64 samples analyzed. Counting was performed at the laboratory following Utermöhl (1931) using a Nikon TE-200 inverted microscope at magnification X 200. Counted volume varied 
between 50 and $100 \mathrm{~mL}$ depending on cell concentration. Every planktonic cell examined was counted and identified at the lowest possible taxonomic level. For diatoms, we counted separately cells that were intact (e.g. complete frustule with chloroplasts), empty (e.g. complete frustule devoid of internal content), broken (e.g. frustule with a clean break at the girdle band junction or partly dissolved), or crunched (e.g. frustule with a jagged break outside of the girdle junction; see supplementary Figure S1 for illustrating pictures), as recommended by Assmy et al. (2013). Many mortality pathways can explain the presence of empty and broken frustules (Tréguer et al., 2018), whereas crunched frustules are likely due to handling by copepod mandibles (Assmy et al., 2007). [ue to the low magnification, taxonomic identification to the species level was occasio 'ari' uifficult and necessitated categorizing diatom species to the genus or taxa grcupings in the following manner: Chaetoceros spp. Hyalochaete resting spores (CRS) we e not differentiated into species or morphotypes but were counted separately fro: $\mathrm{t}$ l e vegetative cells; Fragilariopsis separanda and Fragilariopsis rhombica were gre *ned as Fragilariopsis separanda/rhombica; most of the small $(<10 \mu \mathrm{m})$ and intermediatc $(1\llcorner j 0 \mu \mathrm{m})$ unidentified centric diatoms were grouped as Actinocyclus spp./Thalassio ra ,pp., after we identified these two genera as the dominant ones, based on SEM imag $\varsigma$. For some taxa exhibiting a wide range of sizes, size classes were defined to better estir $10 .$. their carbon biomass. Finally, for a few species, we also distinguished different moıph '́ngical forms and life stages (Figure S2). In Odontella weissflogii, we counted sepaıtely vegetative cells (rectangular, lightly silicified, with 4 processes located on eacr va ve), resting cells (more rounded and silicified, with two processes on each va've, $a^{r}, d$ resting spores (oval shape, heavily silicified, with very short processes) (Hoban et a' 980). In Eucampia antarctica, many different morphological forms were observed: a typical form (i.e. heavily silicified, asymmetric cells that form coiling chains), a H-shape form, a flat form without horns, and some intermediate forms. Finally, three forms of Chaetoceros atlanticus were distinguished: a colonial form with cells having long and straight setae, a single cell form with sigmoidal thickened setae, and a 'bulbosum' form characterized by a single cell enriched with lipids and with short and inflated setae. Although non-exhaustive, a detailed list of taxa is presented in supplementary Table S1, along with linear measurements used to estimate biovolumes and carbon biomasses. 


\subsection{Estimation of the diatom $\mathrm{C}$ biomass}

Specific C biomass was assessed only for diatoms, following the methodology described in Cornet-Barthaux et al. (2007). When possible, cell dimensions were determined from at least 20 representative cells for each species/taxon and for each sample. When the third dimension was not measurable due to the cell's position on the slide (e.g. the transapical axis of Fragilariopsis species, or the pervalvar axis of numerous centric), the hidden dimension $(h d)$ was estimated by using mean dimension ratios from other comparable samples where hd was measured. For a few taxa (e.g. centrics such as Asteromphalus spp.), hd was not measured in any sample. In these cases, we used tr : visible to hidden dimension ratio documented for the same genera in European star daris (Afnor, 2015). For each measured cell, a biovolume was estimated using line ir a mensions in the appropriate geometric formula reflecting the cell shape (Afnor $v_{-5}$ ). A mean biovolume was then estimated for each taxon and converted to carbc. content per cell according to the corrected equation of Eppley (Smayda, 1978) as fr il vws:

$$
\left.\log _{10} C \text { biomass }(\mathrm{pg})=0.7=1.00^{\circ} \text { (cell volume }\left(\mu \mathrm{m}^{3}\right)\right)-0.352
$$

CRS carbon content was estimated using : 'e volume-to-carbon relationship of $0.039 \mathrm{pmol} C$ $\mu \mathrm{m}^{-3}$ established from the resting spu re of Chaetoceros pseudocurvisetus (Kuwata et al., 1993). C content per cell (pg cell ${ }^{-1}$ ) wi $s$ nultiplied by cell abundance (cells $\mathrm{L}^{-1}$ ) to derive total carbon biomass per taxon, expre -sed in units of $\mu \mathrm{g} \mathrm{CL}^{-1}$. Total diatom carbon biomass was then compared to chemica.' $"$ ' letermined POC concentrations to yield a percentage contribution of diatoms + , : he cotal POC fraction.

\subsection{Diatom-spe :ific contribution to silica deposition}

Taxon-specific silica production was quantified using the fluorescent dye PDMPO. Leblanc and Hutchins (2005) have shown that the dye is incorporated in a nearly constant ratio with biogenic silica during the synthesis of the frustule, allowing semi-quantification of newly deposited Si at the specific level using epifluorescence microscopy. However, McNair et al. (2015) observed a linear decrease in the BSi : PDMPO incorporation ratio when ambient silicic acid concentration fall below $3 \mu \mathrm{mol} \mathrm{L^{-1 }}$. Hence, it is important to keep in mind that for a given PDMPO fluorescence, the amount of BSi synthetized might be higher at stations where $\mathrm{Si}(\mathrm{OH})_{4}$ reached $3 \mu \mathrm{mol} \mathrm{L} \mathrm{L}^{-1}$. For each station/visit, seawater samples were collected at 5 different depths corresponding to different levels of PAR $(50 \%, 25 \%, 4 \%, 1 \%$ and $0 \%$ of 
surface irradiance). For each sample, $150 \mathrm{~mL}$ of seawater were spiked onboard with 0.125 $\mu \mathrm{M}$ PDMPO (final concentration). Samples were then placed in deck incubators cooled by running sea surface water and fitted with blue plastic optical filters to simulate the light attenuation of the corresponding depth. After $24 \mathrm{~h}$, samples were filtered onto $0.6 \mu \mathrm{m}$ black Nucleopore polycarbonate filters. Filters were directly mounted onto permanent glass slides and stored in the dark at $-20^{\circ} \mathrm{C}$ until analysis. Back at the laboratory, microscope slides were observed under a Zeiss Axio Observer Z1 inverted fluorescence microscope equipped with an Xcite 120LED source and a CDD black and white AxioCam-506 Mono (6 megapixel) camera fitted with a filter cube (Ex: 350/50; BS 400 LP; [m: 535/50). For each taxon, fluorescent cells were identified and counted, and we diff - it tlated between valves and girdle bands, since those two parts of the frustule do not 'illity at the same stage during the cell cycle, and also do not have the same area nor deg, 'e or silicification (i.e. the amount of BSi deposited per unit surface), and should thus not he c smpared directly. In each sample, a representative number of images was taken for = $\mathrm{ch}$ taxon (at least 20 images for the most common taxa). PDMPO fluorescence intensi $y$ w.us then quantified using a custom-made IMAGE J routine on original TIFF images. Th's routine needs to be changed depending on the format of images and associated inf. mation and can be made available upon request to the corresponding author. The taxon-s, $e_{r},{ }_{i}{ }_{i r}$ contributions to silica production were estimated by multiplying the number of flı. ort: rent cells by the mean fluorescence per cell. The total fluorescence per taxon was exp - assed in AU (arbitrary unit) $\mathrm{L}^{-1}$. Based on the images we also estimated the degree of $s_{1}^{\prime}$ : rif cation for the most active taxa by dividing individual cell fluorescence by its cc.re.nor. ding frustule surface.

\subsection{Statistical analysis}

Multivariate analyses were performed on total diatom abundances (i.e. including both intact and detrital cell counts) using MATLAB, version 8.4 (MathWorks). The abundances were $\log (x+1)$ transformed to decrease the importance of numerically dominant taxa. Bray-Curtis dissimilarities were then calculated between each pair of samples, and a cluster analysis was run using the complete linkage algorithm (Legendre and Legendre, 2012). An arbitrary threshold was applied to separate samples into compact clusters. A non-metric multidimensional scaling (NMDS) was also performed on total diatom abundances. The NMDS displays the relative similarity between samples as the distance between points in a 
two-dimensional space. Hence, tightly grouped samples are more similar than widespread data points, thereby providing a visual representation of community differences. A comprehensive list of the taxa included in these two analyses is presented in supplementary Table S2.

\section{Results}

\subsection{Hydrographic context}

The mixed layer depth (MLD) at the first visit did not exhibit large variations between stations, ranging between 63-79 m (Table 1). M1 was weaklv - tratified and exhibited the shallowest MLD. Following a large storm event (10 March), thr. MLD deepened slightly at M2-3 (80 m), and more importantly at M3-3 and M4-2 'ho h at $96 \mathrm{~m}$ ). The depth of the euphotic zone (Ze) was shallower above the plateal rt'erence station (58-64 m) compared to the other stations (89-105 m).

Average vertical profiles of $\mathrm{Chl} a$ concf.itı tic.?s calculated from several visits at a same station are presented in Figure 2.a. Phyto, 'ankton biomass was low at the 4 stations and mostly distributed in the upper $125 \mathrm{~m}$, vith the highest concentrations (up to $0.4 \pm 0.2 \mu \mathrm{g}$ $\mathrm{L}^{-1}$ ) reached at the plateau referer-e _+.tion $\mathrm{M} 2$. Station $\mathrm{M} 3$ and $\mathrm{M} 4$, located on the western side of the Kerguelen Plateaı., $p_{1}$ ssented the lowest $\mathrm{Chl} a$ concentrations $\left(<0.2 \mu \mathrm{g} \mathrm{L}^{-1}\right)$ whereas M1 presented interm c tiate concentrations (0.3-0.4 $\left.\mathrm{g} \mathrm{L}^{-1}\right)$ in the upper $75 \mathrm{~m}$. The third visit at $\mathrm{M} 2$ was $\mathrm{m}$ arke $\mathrm{d}$ by an increase in $\mathrm{Chl} a$ (up to $0.6 \mu \mathrm{g} \mathrm{\textrm {L } ^ { - 1 }}$ at $50 \mathrm{~m}$, data not shown) following the sto, $n$ event, explaining the larger standard deviation at this site.

Average profiles of silicic acid, nitrate, phosphate, and ammonium concentrations are presented in Figure 2.b-e. Silicic acid concentrations were depleted in the upper $75 \mathrm{~m}$, especially at station $\mathrm{M} 2$ and $\mathrm{M} 3$, ranging between 1.7-3.1 $\mu \mathrm{mol} \mathrm{L}^{-1}$. In comparison, moderate to elevated silicic acid concentrations were observed at M4 (up to $4.8 \mu \mathrm{mol} \mathrm{L^{-1 }}$ within the upper $75 \mathrm{~m}$ ) and $\mathrm{M} 1$ (up to $6.9 \mu \mathrm{mol} \mathrm{L^{-1 }}$ within the upper $50 \mathrm{~m}$ ). Nitrate and phosphate concentrations were replete in the upper $75 \mathrm{~m}$ and ranged between 21.5-25.1

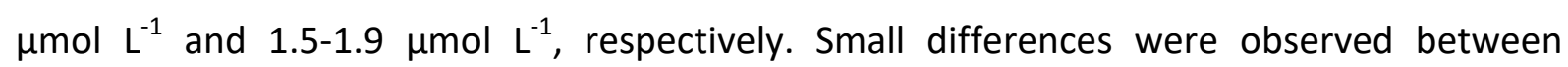
stations and visits, as evidenced by the low standard deviations. Maximum $\mathrm{NH}_{4}^{+}$ 
concentrations ranged between 0.9-1.3 $\mu \mathrm{mol} \mathrm{L}^{-1}$ for the 4 stations, and were usually located in sub-surface.

\subsection{Elemental composition (Si, N, C) and stoichiometry of particulate matter}

\subsubsection{Vertical distribution of particulate matter}

$\mathrm{BSi}, \mathrm{POC}$, and PON vertical distributions are presented in Figure 3. Stations $\mathrm{M} 2, \mathrm{M} 3$, and M4 were characterized by a marked deep silica maximum (DSM) at the first visit that progressively diminished throughout the survey, whereas no DSM was observed at M1. At $\mathrm{M} 2$, the DSM was located at $100 \mathrm{~m}$ where BSi reached $1.1 ; \mathrm{mol} \mathrm{L}^{-1}$ at the first visit, decreasing to $0.7 \mu \mathrm{mol} \mathrm{L}{ }^{-1}$ at the last visit (18 days later), wh ie an increasing trend was observed in the upper $75 \mathrm{~m}$. At M3, BSi concentratio is re= shed $2.0 \mu \mathrm{mol} \mathrm{L} \mathrm{L}^{-1}$ at the DSM located at $125 \mathrm{~m}$, which deepened down to $150-175 \mathrm{~m}$ । $7 \mathrm{t}$ the next visit (15 days later). The highest siliceous biomass was measured at station $\mathrm{N}_{14}$, i cated upstream of the Fe-fertilized plateau, where BSi reached $3.2 \mu \mathrm{mol} \mathrm{L}{ }^{-1}$ at the $\mathrm{SSI} \wedge(75 \mathrm{~m})$ during the first visit. At M1, Si biomass decreased regularly with depth ar $d$ river exceeded $1.0 \mu \mathrm{mol} \mathrm{L} \mathrm{L}^{-1}$. Throughout the study area, BSi concentrations were still el 'ated down to 350-500 m, varying between 0.3 and $0.8 \mu \mathrm{mol} \mathrm{L}^{-1}$, with the highest val' 'es neasured at $\mathrm{M} 2$.

POC and PON vertical distribı,cioı, differed from BSi, with a decreasing trend with depth. Highest concentrations wore neasured at M2-3, where POC and PON concentrations

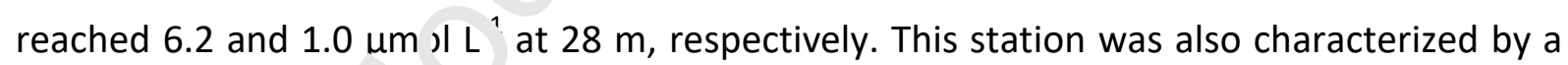
large increase in POC ani PON concentrations at $450 \mathrm{~m}$, likely reflecting an organic material resuspension event after the storm. Apart from M2-3, no large differences were observed at the surface, with POC and PON varying respectively between 3.3-5.5 $\mu \mathrm{mol} \mathrm{L}^{-1}$ and 0.6-0.9 $\mu \mathrm{mol} \mathrm{L} \mathrm{L}^{-1}$, while at the last sampled depths they varied between 0.5-1.9 and 0.1-0.2.

\subsubsection{Depth-integrated standing stocks}

BSi, POC, PON, and Chl $a$ concentrations were integrated between 0 and $200 \mathrm{~m}$ (Figure 4; see supplementary Figure S3 for integrated concentrations between 200-500 m), independently of the mixed-layer depth because significant biogenic and organic particulate material was measured between 100 and 200 m (Figure 3). Integrated BSi ranged between 
134-219 $\mathrm{mmol} \mathrm{m} \mathrm{m}^{-2}$ at M1/M2/M3, and a decreasing trend was observed during the survey. In line with vertical profiles, BSi standing stocks were larger at M4 (up to more than twice) where it reached $493 \mathrm{mmol} \mathrm{m}^{-2}$ at the first visit, decreasing to $339 \mathrm{mmol} \mathrm{m}^{-2}$ at the second visit. POC and PON standing stocks ranged between 448-756 $\mathrm{mmol} \mathrm{m}^{-2}$ and 73-108 $\mathrm{mmol} \mathrm{m}^{-2}$ respectively, with maximum values measured at M2-1 and lowest values measured at M3-3. Contrary to $\mathrm{BSi}$, no large variations were observed between stations. A decreasing trend was observed between the first and the second visit at $\mathrm{M} 2 / \mathrm{M} 3 / \mathrm{M} 4$, but integrated stocks increased after the storm event at the plateau reference station $\mathrm{M} 2$ ( $3^{\text {rd }}$ visit). Chl $a$ standing stocks did not vary a lot spatially, especially between $M 1 / M 3$ 'M4 where it ranged between 20-33 $\mathrm{mg} \mathrm{m}^{-2}$. Above the plateau, it varied between 30-53 $\mathrm{m}_{5} \mathrm{n}^{--}$, with the largest increase observed during the last visit, after the storm event.

\subsubsection{Stoichiometry of particulate matter}

The elemental ratios within the upper mixed li ye (0-MLD) and the subsurface layer (MLD$200 \mathrm{~m}$ ) are presented for the 8 visits at the 1 stations (Figure 5) to highlight some spatial and/or temporal patterns over the stuay $\rightarrow$ ea. Within the $M L$, the most striking feature was the elevated $\mathrm{Si}: \mathrm{C}$ and $\mathrm{Si}: \mathrm{N}$ ratios at $\mathrm{N}: 1$ (both visits), with average values ranging between 0.54-0.67 and 3.42-4.05, respective' $y$ r - the other stations, Si:C (0.14-0.20) and Si:N (0.781.16) ratios were much closer $\mathrm{t}$ : the empirical 0.13 and 1.12 values reported by Brzezinski (1985) for diatoms grown in nu -ient-replete medium. Below the MLD, Si:C and Si:N ratios increased rapidly at ever: si ${ }^{+i}$ ion with average values ranging respectively between 0.35 1.06 and 2.13-6.58, $w_{1}: 4,1 .-1$ still displaying the highest ratios. The average $\mathrm{C}: \mathrm{N}$ ratios were close to the 6.62 Redfinid empirical value. In contrast to Si:C and Si:N, no large variations were observed between the 0-MLD (average: 5.71-6.32) and MLD-200 m layers (6.02-8.38).

3.3 Diatom community structures: abundances, carbon biomasses, and silica deposition activity

\subsubsection{Diatom contribution to particulate organic carbon (POC)}

Absolute diatom carbon biomass and its relative contribution to POC are presented in Figure 6. Above the plateau (M2), diatom carbon biomass increased progressively between the first and last visits, on average from $10.2 \pm 3.1 \mu \mathrm{g} \mathrm{CL}^{-1}(17 \pm 6 \%$ of POC; $\mathrm{n}=4)$ to $30.7 \pm 2.4 \mu \mathrm{g} \mathrm{C}$ 
$\mathrm{L}^{-1}(43 \pm 6 \%$ of $\mathrm{POC})$ within the upper $75 \mathrm{~m}$. The highest diatom $\mathrm{C}$ biomass measured throughout the survey was reached during the last visit at $M 2\left(34.1 \mu \mathrm{g} \mathrm{C} \mathrm{L}^{-1} ; 69 \mathrm{~m}\right)$, representing $52 \%$ of POC biomass. At the first visit, diatom C biomass was homogeneous down to $100 \mathrm{~m}$ due to the accumulation of large Eucampia antarctica cells at this depth, while during the two following visits, it decreased rapidly below the MLD, where on average only $3.5 \mu \mathrm{g} \mathrm{C} \mathrm{L}{ }^{-1}$ (16\% POC) and $2.0 \mu \mathrm{g} \mathrm{C} \mathrm{L}^{-1}$ (10\% POC) remained, respectively. It is interesting to notice the low but quasi constant diatom carbon biomass within the 100-200 $\mathrm{m}$ layer at the last two visits, which contrasts with the other stations. At the off-plateau station $\mathrm{M} 4$, diatom $\mathrm{C}$ biomass was stable within the upper $10 \mathrm{~m}$ at the two visits, averaging $10.5 \pm 1.8 \mu \mathrm{g} \mathrm{CL}^{-1}(24 \pm 6 \%$ of POC; $\mathrm{n}=8)$. Lowest $\mathrm{C}$ biomass ve $: e$ ineasured at $\mathrm{M} 3$, where it averaged $2.1 \pm 0.6 \mu \mathrm{g} \mathrm{CL} L^{-1}(6 \pm 2 \%$ POC; $n=8)$ at the two vis. ${ }^{+}$. These low biomasses can be explained by both lower abundances and the presence of aratoms having small biovolumes. In particular, the genus Fragilariopsis spp. was most:; col lposed of small F. pseudonana $<10$

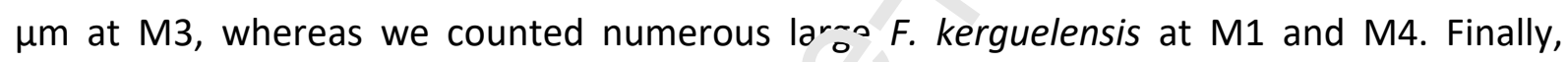
diatom $\mathrm{C}$ biomass at $\mathrm{M} 1$ was homogeneous ir th upper mixed layer $\left(9.6 \pm 0.3 \mu \mathrm{g} \mathrm{C} \mathrm{L}^{-1} ; 16 \pm\right.$ $1 \%$ of POC), then decreased progressii sly with depth towards quasi non detectable values below $100 \mathrm{~m}$.

\subsubsection{Absolute diatom ar: $: n c^{\sim}{ }^{\sim}$,ces}

The vertical profiles of diato ' a ' 'Indances with the contribution of full, empty, broken, and crunched frustules are proce. ${ }^{+}-d$ in Figure 7. Overall, total diatom abundances peaked at 50 $m$ and then decreas $\gamma$. ugressively with depth, except at station $M 2$ where higher abundances were obs_.ved below the MLD, and at M3-3 where abundances were homogeneous in the 50-200 m layer. In the upper 75-100 m, abundances were higher at stations $\mathrm{M} 1$ and M4, ranging between 9.9 to $16.8 \times 10^{4}$ cells $\mathrm{L}^{-1}$, with the highest number of cells reached at M4-2 $(50 \mathrm{~m})$. In contrast, lower abundances were measured at M2 in the upper $75 \mathrm{~m}$, although we observed a progressive increase between the first and last visit, from $3.2 \pm 0.9 \times 10^{4}$ cells $L^{-1}(n=4)$ to $5.8 \pm 0.3 \times 10^{4}$ cells $L^{-1}$. The contribution of intact cells to total diatom abundances decreased rapidly below $75 \mathrm{~m}$ at M1/M2, whereas it declined significantly only below $100 \mathrm{~m}$ at M3/M4 (see also Figure S4). Over the study area, it was homogeneous in the surface layer, with an average contribution of $66 \pm 8 \%(n=31)$. Above the plateau, numerous intact cells were still observed in the deepest samples located 
between $175-200 \mathrm{~m}$ (up to $48 \%$ at M2-2), while only 3-12\% of diatoms were still intact at the other stations. The average percentage of empty and broken cells increased with depth from respectively $24 \pm 5 \%$ and $3 \pm 2 \%$ at the surface $(n=8)$ to $55 \pm 9 \%$ and $19 \pm 9 \%$ in the deepest samples. The percentage of crunched diatoms, which we consider as indicative of mesozooplankton grazing, did not exhibit either any obvious vertical or spatial trends $(5 \pm 3$ $\% ; n=64)$.

\subsubsection{Taxon-specific contribution to total diatom abundances}

Both a cluster analysis and a non-metric multidimensional scá:" ig analysis (Figure 8.a and b) performed on total abundances at all sites and depths revei lea 7 strong vertical and spatial structure of diatom communities. The first clustering ract $\mathrm{rr}$ is based on depth, clearly separating samples collected between 0 and 75/100 ㄱ. (depending on the station) from samples collected below, between 100/125 and $2 b_{i} \mathrm{~m}$. Secondly, within surface samples, $\mathrm{M} 2$ is isolated from the other three stations $\mathrm{vl}_{\mathrm{ir}}$ ch cluster together, while at depth two different clusters (M1/M2 vs M3/M4) are ic'sntiried. The stress value of the NMDS (0.11) indicates a fair model-data fit. The NML $\subset$ slot confirms that the four clusters are different from each other in terms of their l vonomic composition, with the first axis separating diatom communities according to $h^{\prime}$ il depth, while the second axis highlights the spatial heterogeneity.

Taxon-specific contribution Li iotal diatom abundances is presented in Figure 8.c. In the upper $75 \mathrm{~m}$, diatom $n_{1}$....unity structure above the plateau reference station M2 was clearly distinct from ti..c observed at the other sites. At the first visit, diatoms were dominated by Actinocyclus/Thalassiosira spp. (29 $\pm 3 \%$; $n=4)$, Thalassionema nitzschioides (17 $\pm 3 \%)$, Guinardia cylindrus (13 $\pm 1 \%$ ), Corethron spp. (only C. inerme; $12 \pm 1 \%$ ), and Cylindrotheca closterium ( $7 \pm 4 \%$ ). A temporal evolution was observed at this station, with the third visit marked by the increasing contribution of $C$. inerme $(27 \pm 3 \%), T$. nitzschioides (28 $\pm 5 \%)$ and Cylindrotheca closterium (15 $\pm 3 \%$ ), while Actinocyclus/Thalassiosira spp. and G. cylindrus decreased. As shown by the cluster analysis, diatom communities in the upper 75-100 m layer were similar between $\mathrm{M} 1 / \mathrm{M} 3 / \mathrm{M} 4$ and were dominated by a mix of Cylindrotheca closterium (23 $\pm 14 \%)$, Actinocyclus/Thalassiosira spp. $(20 \pm 5 \%)$, and Fragilariopsis kerguelensis (16 $\pm 10 \%)$. Below the MLD, the diatom community at M2-1 was 
characterized by the presence of large and heavily silicified cells of Eucampia antarctica (13 $\pm 6 \% ; n=4$ ) which almost disappeared at the following visits. Excluding this species, deep diatom communities at M2/M1 were similar and dominated by a mix of CRS ( $27 \pm 10 \%$; $\mathrm{n}=17)$, Pseudo-nitzschia spp. (15 $\pm 9 \%)$, Fragilariopsis kerguelensis (13 $\pm 5 \%)$, Chaetoceros spp. (13 $\pm 7 \%$; mostly as small Chaetoceros sp. Hyalochaete), and Actinocyclus/Thalassiosira spp. (10 $\pm 5 \%$ ). Deep communities at stations M3/M4 formed a distinct cluster and were dominated by a mix of Fragilariopsis kerguelensis ( $37 \pm 9 \% ; n=16)$, Chaetoceros atlanticus (23 $\pm 13 \%)$, Pseudo-nitzschia spp. (13 $\pm 5 \%)$, and Actinocyclus/Thalassiosira spp. (11 $\pm 3 \%)$, while the contribution of CRS was minor at these sites.

When looking at the taxon-specific contribution ts itact and detrital cells (see supplementary Figure S5-8), some trends emerged. The only species that was almost exclusively observed intact at all sites within the $\mathrm{n}$. ved layer was Cylindrotheca closterium reflecting its possible recent growth and good hyysiological state at the time of sampling. Below the MLD, Chaetoceros atlanticus and he cher Chaetoceros species (including both vegetative and resting stages) were tr. $\mathrm{r}$.ain contributors to intact cells, at M3/M4 and M2/M1 respectively, while Fragilaric,nsis kerguelensis cells were mostly detrital (i.e. empty, broken or crunched). Crunched irı, +illes were mainly associated with the pennate Fragilariopsis kerguelensis $1+2 \pm 21 \%$; $n=64)$ and the centric genera Actinocyclus/Thalassiosira spo. '? $4 \pm 15 \%$ ), suggesting a selective grazing.

\subsubsection{Taxon-spe cific contribution to diatom carbon biomass}

Taxon-specific contribli:ion to diatom carbon biomass is presented in Figure 9. At the reference plateau station $\mathrm{M} 2$, diatom carbon biomass was dominated within the upper $75 \mathrm{~m}$ (i.e. corresponding to the MLD) by the large centric species Corethron inerme, whose average contribution to biomass increased from $59 \pm 3 \%\left(1^{\text {st }}\right.$ visit, $\left.n=4\right)$ to $83 \pm 5 \%$ ( $3^{\text {rd }}$ visit). Important contributors were also Guinardia cylindrus at the first visit (19 $\pm 5 \%$; $=4)$, followed by species belonging to Proboscia/Rhizosolenia genera (mostly P. alata and $R$. chunii) whose contribution was $10 \pm 4 \%(n=12)$ at the three visits. The taxa Actinocyclus/Thalassiosira spp., Thalassionema nitzschioides, Pseudo-nitszchia spp., and Cylindrotheca closterium which were key contributors to diatom abundances did not contribute significantly to $C$ biomass, due to their low biovolumes. Below the MLD, C 
biomass was largely dominated by Eucampia antarctica at the first visit (58 $\pm 11 \%$; $=4)$. Its contribution rapidly decreased at the following visits (11 $\pm 9 \% ; 3^{\text {rd }}$ visit), being replaced by CRS $(27 \pm 18 \%)$ and Chaetoceros spp. $(23 \pm 17 \%$; mostly the small Chaetoceros sp. Hyalochaete). Apart from M2, the community structures at the other stations appeared more diverse. The large centric species Proboscia/Rhizosolenia spp. contributed significantly to carbon biomass throughout the water column, except below $100 \mathrm{~m}$ at M1 (mostly $P$. inerme and $R$. chunii; $18 \pm 11 \%, \mathrm{n}=35$ ). Species belonging to Actinocyclus/Thalassiosira genera were also important contributors all over the water column (21 $\pm 10 \%$; $=40$ ). Although a vertical structure was less obvious compared with diatom abundances (Figure 8), Chaetoceros atlanticus contributed significantly to C biomas w low the MLD at M3/M4 (26 $\pm 15 \% ; n=18$ ), while Chaetoceros spp. (mostly the small -metoceros sp. Hyalochaete; $22 \pm$ $12 \% ; n=5)$ and CRS (22 $\pm 13 \%)$ were the main ontributors at M1 below $100 \mathrm{~m}$. Interestingly, one can notice the much lower contri'. ' Itic / of Fragilariopsis kerguelensis to C biomass in comparison with diatom abundancer, which can be linked to its high percentage of detrital frustules, especially below the mix id iny er, as well as to their small C content per cell (149 pg C cell ${ }^{-1}$; see supplementa $v$ T able S1). Although it had one of the smallest biomasses (8-25 pg C cell ${ }^{-1}$ ), Cylindro heca closterium contributed on average to $17 \pm 11 \%$ of diatom $C(n=8)$ in the upper $100 \mathrm{~m}$, M3, due to elevated abundances. Corethron spp. contributed significantly to $C$ bin nas- at some depths at station M1/M3/M4, but unlike $M 2$, it belonged mainly to the specle - $C$. pennatum.

\subsubsection{Taxon-spe cific contribution to biogenic silica deposition}

The contribution of ea々.. taxon to biogenic silica deposition is presented in Figure 10. The diversity appears smaller than in the previous figures for several reasons: first, species identification is harder in epifluorescence than in bright-field microscopy and leads to downgrading of the upper taxonomic level; second, because less species were actively silicifying in a given sample relative to the total number of taxa, meaning that some species were not active at the time of the incubation even though present as intact cells.

Above the plateau station M2, total PDMPO fluorescence increased progressively between the first and the last visit from a maximum of $4.1 \times 10^{6} \mathrm{AU} \mathrm{L}^{-1}(\mathrm{M} 2-1 ; 19 \mathrm{~m})$ to $12.1 \times 10^{6} \mathrm{AU}$ $\mathrm{L}^{-1}(\mathrm{M} 2-3 ; 9 \mathrm{~m})$. This increasing silicification activity was associated with the development of 
Corethron inerme whose average contribution to total silicification was low at M2-1 (13 \pm 10 $\% ; n=3)$, but increased to $52 \pm 9 \%(n=4)$ and $47 \pm 6 \%(n=4)$ at $M 2-2$ and $M 2-3$, respectively. Proboscia/Rhizosolenia spp. (mostly $P$. alata) were also actively silicifying, with an average contribution of $39 \pm 16 \%(n=11)$ to PDMPO fluorescence throughout the survey. Fragilariopsis spp. cells (likely including F. kerguelensis, although identification to the species level was difficult) were actively silicifying at this station, albeit as a smaller contributor (14 \pm $10 \% ; n=11$ ). At $M 2$, we also incubated samples that were collected at 100 and $125 \mathrm{~m}$ (data not shown), but silicification activity was almost null, and we did not observe any labelled Eucampia antarctica or CRS, although they were important CC itributors to both abundances and $\mathrm{C}$ biomass at those depths. The lowest total PDMPO flur it_- rence was measured at M3$1\left(<1.0 \times 10^{6} \mathrm{AU} \mathrm{L}^{-1}\right)$ where silicification activity was alm « ? onstant throughout the upper $100 \mathrm{~m}$. Very few taxa contributed to biogenic silica dep sitıon, which was dominated by the activity of Fragilariopsis spp. (48 $\pm 17 \% ; n=4)$ ar: Ac inocyclus/Thalassiosira spp. centric cells $(44 \pm 15 \% ; n=4)$. By contrast, the highest $+a+$ al PDIMPO fluorescence was measured at $\mathrm{M} 1$, reaching $25.0 \times 10^{6} \mathrm{AU} \mathrm{L}^{-1}$ at the surface seı.e decreasing progressively with depth. At this station, Fragilariopsis spp. and Acti. $\mathrm{nc}^{\prime}$ clus/Thalassiosira spp. were the most important contributors down to $90 \mathrm{~m}$ (respectiv •ly $31 \pm 18 \%$, and $30 \pm 19 \% ; n=4$ ). Actively silicifying Corethron pennatum were also obs $\mathrm{rv}=\mathrm{\gamma}$ at the surface $(47 \%$ at $13 \mathrm{~m})$, whereas Rhizosolenia spp. and Chaetoceros spp. were sbs:rved deeper, contributing respectively to $21 \%$ at $60 \mathrm{~m}$ and $10 \%$ at $90 \mathrm{~m}$. At the refert.'se HNLC station M4, total PDMPO fluorescence was close to M1, reaching $21.0 \times 10^{6} \mathrm{AL} \mathrm{I}^{-}$at M4-1 $(29 \mathrm{~m})$. This station was also the most diverse in terms of silicifying $c 0\urcorner , m \cdot n^{+} y$. Indeed, throughout the two visits $(n=8)$, many different taxa were producing ne's frustules, including Fragilariopsis spp. $(30 \pm 12 \%)$, Actinocyclus/Thalassiosira spp. (21 $\pm 10 \%)$, Proboscia/Rhizosolenia spp. (16 $\pm 13 \%)$, Corethron pennatum (9 $\pm 11 \%)$, Chaetoceros dichaeta (5 $\pm 5 \%)$, C. atlanticus ( $4 \pm 4 \%)$, and Membraneis spp. (4 $\pm 6 \%$ ). Based on McNair et al. (2015) experimental results, which showed that the BSi : PDMPO incorporation ratio was higher at $\left[\mathrm{Si}(\mathrm{OH})_{4}\right]>3 \mu \mathrm{mol} \mathrm{L}^{-1}$, it is plausible that relative differences between $\mathrm{M} 1 / \mathrm{M} 4\left(\left[\mathrm{Si}(\mathrm{OH})_{4}\right]>3 \mu \mathrm{mol} \mathrm{L}^{-1}\right.$ within the mixed layer) and $\mathrm{M} 2 / \mathrm{M} 3\left(\left[\mathrm{Si}(\mathrm{OH})_{4}\right]<3 \mu \mathrm{mol} \mathrm{L}^{-1}\right)$ in terms of total PDMPO fluorescence would be even higher if converted to new BSi. 


\subsection{Species-specific properties driving diatom elemental stoichiometry}

\subsubsection{Diatom Si:C ratio}

Si:C ratios based on calculated diatom carbon biomass (defined hereafter as $\mathrm{Si}: \mathrm{C}_{\text {diatom }}$ ) instead of total POC are presented in Figure 11 . Within the $\mathrm{ML}, \mathrm{Si}: \mathrm{C}_{\text {diatom }}$ ratios were well above the 0.13 value reported by Brzezinski (1985) with the highest values measured at M3/M4 (range: 2.4-3.6), intermediate values at M1 (1.2-1.3), and the lowest ones at M2 (range: 0.4-0.9). Above the plateau, a decreasing trend was observed throughout the survey period. Overall, such elevated $\mathrm{Si}: \mathrm{C}_{\text {diatom }}$ ratios in the upper lay can be explained by several factors including the presence of detrital frustules, a high sili ification degree, or a low carbon content per cell. Below the $\mathrm{ML}$, Si: $\mathrm{C}_{\text {diatom }}$ ratios incr ?ased drastically with average values between 3.7-20.8, evidencing the preferential $r_{t}$-vcling of soft organic matter over BSi dissolution. At $200 \mathrm{~m}$, where a significant fractic. ' $;$ i diatom organic matter is likely to have been remineralized, Si: $\mathrm{C}_{\text {diatom }}$ were still $\mathrm{m} \lambda \mathrm{c}^{\mathrm{r}}$. 'ower at $\mathrm{M} 2$ in comparison with stations located outside the plateau.

\subsubsection{Diatom silicification de rree}

The degree of silicification (i.e the ( $u$ :ntity of BSi deposited per surface unit) was semiquantitatively estimated by nc $n_{1}$ lizing the PDMPO fluorescence of each labelled cell with its labelled surface area (expre-sed in Arbitrary fluorescence Unit per $\mu \mathrm{m}^{-2}$ ). Figure 12 shows the degree of silicificatic. $1 \varkappa^{r}$ the most important contributors to BSi deposition. Small $(<10$ $\mu \mathrm{m})$ Actinocyclus/Thalu_ciosira spp. were less silicified at the iron-fertilized station M2 during the first two visits (Mann-Whitney $U$ test, $p<0.05$ ), whereas no significant differences were observed between the other stations. This was even more evident for the 10-30 $\mu \mathrm{m}$ size fraction characterized by a mean silicification degree equal to $0.51 \pm 0.30 \mathrm{AU}$

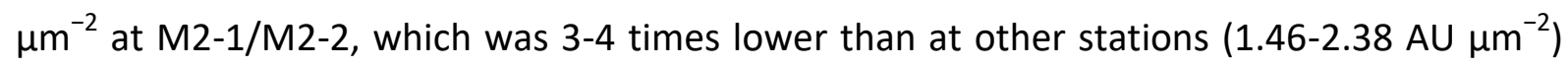
but tended to increase during the successive visits. Diatoms belonging to the genus Fragilariopsis (small and large) were the most heavily silicified of all actively silicifying species. However, statistical analysis showed their degree of silicification was significantly lower at M2 (range: 2.44-2.70 AU $\mu \mathrm{m}^{-2}$ and 1.40-2.12 $\mathrm{AU} \mu \mathrm{m}^{-2}$ for the size-classes $<10$ and 10-30 $\mu \mathrm{m}$, respectively) in comparison with M1/M4 (range: 3.34-5.39 $\mathrm{AU} \mathrm{m}^{-2}$ and 3.91- 
7.40 $\mathrm{AU} \mu \mathrm{m}^{-2}$ ). Actively silicifying Corethron inerme were mostly observed at station $\mathrm{M} 2$

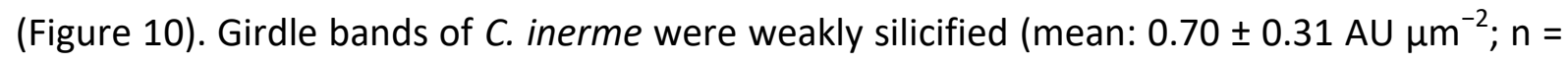
133). Half-valves of $C$. inerme were more silicified with an average silicification degree equal to $2.70 \pm 1.19 \mathrm{AU} \mathrm{\mu m}^{-2}(\mathrm{n}=54)$. Labelled girdle bands of Proboscia alata were also numerous at M2/M4. Again, the degree of silicification was significantly lower at the plateau station $\mathrm{M} 2$ for the three visits $\left(1.58 \pm 0.46 \mathrm{AU} \mu \mathrm{m}^{-2}, \mathrm{n}=111\right)$ compared with the reference HNLC station M4-1 (2.87 $\left.\pm 0.85 \mathrm{AU} \mu \mathrm{m}^{-2}, \mathrm{n}=7\right)$. Although not a dominant contributor to BSi deposition, we found that Chaetoceros atlanticus, an important contributor to both

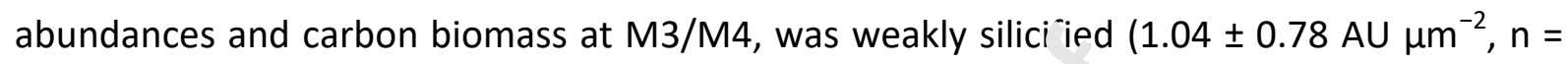
71).

\subsubsection{Diatom species-specific physiological state $k$ $\neg n \cdot v$ the mixed layer}

A detrital:intact cell ratio (defined hereafter as D:I ra ${ }^{n}$ ) גveraged over the deep MLD-250 m layer was calculated to determine the physiol', $\mathrm{g}$-al state of the cells exported out of the mixed layer (Table 2). Following Rembauville 't al. (2015b), we used the threshold values of 2 (representing species mainly observe $d$ as detrital cells) and 0.5 (representing species mainly observed as intact cells). Amu. ' the main contributors to total diatom abundances

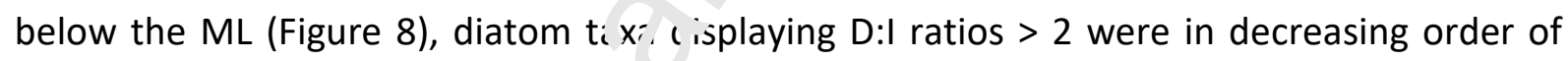
importance: Fragilariopsis kers'eleı,sis, Pseudo-nitzschia spp., Actinocyclus/Thalassiosira spp., and Chaetoceros atlartic:s, indicating those taxa were mostly empty, broken or crunched below the MIn. in stead, Chaetoceros spp. (mostly a small Chaetoceros sp. Hyalochaete) and CRง $\gamma_{1},-1$ dyed $D: I$ ratios $<0.5$ at $\mathrm{M} 2$, meaning they were preferentially found intact below the $\therefore$ L. Eucampia antarctica displayed ratios in between the thresholds $<2$ and > 0.5 at M2-1 where it was an important contributor to diatom abundances, meaning this species was equally represented by full and empty cells. Finally, some taxon that were numerically important at the surface were few in number below the MLD (e.g. Fragilariopsis spp. such as F. pseudonana, Corethron inerme, Cylindrotheca closterium), suggesting they were not efficient vectors for both Si and C export. 


\section{Discussion}

The MOBYDICK results presented above make it possible to draw the major characteristics of the final stage of the seasonal bloom around the Kerguelen Plateau by illustrating the relationships between the structure of its diatom communities and its regional biogeochemistry. While past oceanographic surveys (KEOPS1: January/February 2005; KEOPS2: October/November 2011) identified the physical mechanisms leading to the vertical input of iron-rich deep waters which are responsible for the recurrent plateau bloom development (Blain et al., 2007; Park et al., 2008a), the MOBYDICK project focused on the study of the relationships that exist between the oceanic bio versity and the operation of the biological carbon pump. In this paper we specificall an tress the question of the elemental composition and stoichiometry of particulate nat er and how these parameters may be driven by diatom community composition $7_{11}+$ species-specific properties (e.g. physiological state, life stages, carbon content, silı: : ation degree etc.), above the Fefertilized plateau and in offshore waters.

\subsection{Biogeochemical environm en1; at ihe final stage of the Kerguelen bloom}

At the beginning of our survey (Febl ' ary $26^{\text {hh }}$ ), the siliceous biomass at station M2 located above the Kerguelen Plateau had raia', accumulated within a deep silica maximum (DSM) located at $100 \mathrm{~m}\left(1.7 \mu \mathrm{mol} \mathrm{L} \mathrm{L}^{-1}\right.$, before progressively receding at the following visits. An opposite trend was observed $\therefore$ the upper $75 \mathrm{~m}$ corresponding to the mixed layer $(\mathrm{ML})$, where BSi slightly increasea frrm 0.6 to $0.8 \mu \mathrm{mol} \mathrm{L^{-1 }}$, while a three-fold diatom $\mathrm{C}$ biomass increase (10.2-30.7 $\mu_{i}\left(^{-1}\right.$, occurred following the development of a population of large Corethron inerme. Hov a er, these concentrations were fairly low by comparison to diatom biomasses measured earlier in the season both for Si (up to $21.3 \mu \mathrm{mol} \mathrm{L}{ }^{-1}$; Mosseri et al., 2008) and C (up to $100 \mu \mathrm{g} \mathrm{C} \mathrm{L}^{-1}$; Armand et al., 2008b). Contrary to BSi, Chl a/POC/PON standing stocks did not show large variations between on- and off-plateau stations, which can be attributed to the decaying stage of the yearly bloom. Silicic acid concentrations were depleted (1.2 $\mu \mathrm{mol} \mathrm{L}{ }^{-1}$ at the surface) whereas nitrate and phosphate levels were still elevated, which confirms the high $\mathrm{H}_{4} \mathrm{SiO}_{4}$ uptake affinity of diatoms previously mentioned by Mosseri et al. (2008) over the Kerguelen Plateau. Inputs of $\mathrm{H}_{4} \mathrm{SiO}_{4}$ through vertical mixing enhanced by internal waves (Park et al., 2008a), as well as BSi dissolution evidenced by Closset et al. (2014) could have sustained this persisting diatom community. In addition, a 
large storm event on March $10^{\text {th }}$ with wind speeds up to 50 knots for two days led to a deepening of the MLD during the last visits at M2/M3/M4 (Table 1), enabling a pulse input of $\mathrm{H}_{4} \mathrm{SiO}_{4}$ in the surface layer. This input must have been limited and, although diatom growth was stimulated, we observed a rapid emergence of Si limitation signs on the plateau where $\mathrm{H}_{4} \mathrm{SiO}_{4}$ concentrations and Si:N ratios were at the lowest: (1) SEM images as well as PDMPO single-cell analysis revealed that Corethron inerme frustules were very weakly silicified, with collapsed frustules in most images, (2) germination experiments performed on Odontella weissflogii resting spores (Leblanc et al., in prep.) incubated under two different treatments (light $+\mathrm{Si}+\mathrm{P}$ vs. light only) indicated that $\mathrm{Si}$ iddition was the main factor triggering spore germination.

On the western side of the Kerguelen Plateau, it is $u_{1}$.' ikely that station M3 and M4 were influenced by iron fertilization from the plateau, $d_{i}>$ to the eastward flow associated with the PF (Park et al., 2008b; 2014; Zhou et al., 2011). These two stations were marked by an important deepening of the MLD following tl e siurm (from 69 to $96 \mathrm{~m}$ ) but Ze was always deeper (from 95 to $101 \mathrm{~m}$ ) suggesting t'. 'at siatoms were not prone to light limitation in this area. However, stations M3 and M4 sxhibited contrasted biogeochemical environments. At $M 3$, silicic acid concentrations wer $\leq 1, "$ at the surface $\left(2.4 \mu \mathrm{mol} \mathrm{L}{ }^{-1}\right)$, suggesting a strong $\mathrm{H}_{4} \mathrm{SiO}_{4}$ limitation since Southern $\mathrm{O}_{2}$ ?n diatoms have long been shown to exhibit very high $\mathrm{K}_{\mathrm{S}}$ values for $\mathrm{H}_{4} \mathrm{SiO}_{4}$ under $\mathrm{H}_{1}$ "I.C conditions (Jacques, 1983; Nelson and Tréguer, 1992; Franck et al., 2000; Nelson _+a ., 2001; Quéguiner, 2001; Mosseri et al., 2008). As a matter of evidence, diatom $\mathrm{a} b$.nd Ances decreased sharply throughout the survey period while silicification activity as $\mathrm{w}^{\mathrm{I}} \mathrm{Il}$ as diatom contribution to C (average in the ML: $5 \%$ POC) were the lowest recorded during the cruise. This station has been extensively studied during past oceanographic surveys (e.g. KEOPS1 \& 2) and corresponds to the time series station KERFIX (Jeandel et al., 1998). These studies reported very low diatom productivity year-round in these waters with $\mathrm{C}$ biomass rarely exceeding $3 \mu \mathrm{g} \mathrm{CL}^{-1}$ (Kopczyńska et al., 1998; Lasbleiz et al., 2016), and phytoplankton abundances largely dominated by naked pico- and nanoflagellates (Kopczyńska et al., 1998). According to Pauthenet et al. (2018), the zonal position of the PF is highly variable throughout the productive season on the westernside of the plateau and is located further south by up to $4^{\circ}$ latitude in March compared to September. Hence, it isolates M3 from the southern Antarctic surface water (AASW), giving 
one potential explanation to the lower diatom contribution in this area, since flagellates are known to outnumber diatoms north of the PF (Kopczynska et al., 1986). In a study investigating the whole microplankton community structure across the Subantarctic and Polar Front, Rembauville et al. (2016) also showed that dinoflagellates and ciliates dominated microplankton $\mathrm{POC}$ in the PFZ, while diatoms dominated in the AAZ. Unexpectedly, we measured the highest siliceous biomass at the reference HNLC station M4, where BSi concentrations reached $3.2 \mu \mathrm{mol} \mathrm{L}^{-1}$ at the DSM $\left(1^{\text {st }}\right.$ visit), then started to decrease shortly after. Intermediate silicic acid concentrations were measured $(\approx 4.5 \mu \mathrm{mol}$ $\mathrm{L}^{-1}$ ) that appeared however sufficient for diatoms to grow sin e they were actively silicifying within the upper $100 \mathrm{~m}$ (Figure 10). Elevated BSi concentra'.uv's in HNLC waters were also reported in a similar HNLC environment earlier in the se $\lrcorner \mathrm{s}$, reaching $6.5 \mu \mathrm{mol} \mathrm{L}^{-1}$ at the end of January (Mosseri et al., 2008). Heavily s:'icitıed species (e.g. Fragilariopsis kerguelensis) were particularly abundant at M4-1, hic, likely drove BSi towards elevated values. Hence, our results show that diatoms $>-$ maintain a significant Si biomass in HNLC waters, even exceeding those measured abcive :.'ie plateau at the end of the productive period.

On the eastern side of the Kerguele $1 \mathrm{~F}$ itoau, M1 was likely not limited by nutrients since we did not observe a DSM charact $\epsilon$ rizı ' , nutrient depleted waters and $\mathrm{H}_{4} \mathrm{SiO}_{4}$ concentrations were the highest (range: 6.6-6.? $\mathrm{mmol} \mathrm{L}^{-1}$ ) we have recorded. By contrast with $\mathrm{M} 3$ and $\mathrm{M} 4$, iron could have been supplic $+t$ ) this station by the transport of Fe-rich waters that circulate from the Kerguelen- $i$ ' $a_{1} r s^{l}$.elf basin into the deep basin east of the Kerguelen Islands (van Beek et al., 2008; Park et al., 2014). The ML was weakly stratified, which could have promoted nutrient diffusive input from the deep reservoir. Diatoms in this region were the most actively silicifying, yet they did not reach a significant Si biomass (BSi $<1 \mu \mathrm{mol} \mathrm{L^{-1 }}$ ). Grazing could have prevented biomass accumulation, which is substantiated by elevated concentrations of pheopigments at this station (Irion et al., submitted).

All our observations agree as to the presence of a final phase of the seasonal phytoplankton development on all of the stations studied. However, differences are apparent in the factors controlling the emerging biogeochemical properties. The geographic location in relation to the plateau but also in relation to the PF (via the influence of the AASW) leads us to consider 
a modulation of these properties by the degree of limitation by iron and/or $\mathrm{H}_{4} \mathrm{SiO}_{4}$ and the intensity of grazing, both having direct effects on the structure of phytoplankton communities and their physiological state as will be discussed in the following sections.

\subsection{The influence of diatom communities on C:N:Si elemental ratios}

Redfield (1958) stated that "the environment not only determines the conditions under which life exists, but the organisms influence the conditions prevailing in their environment". Later on, Redfield et al. (1963) provided the bases for reflecting upon the influence of the physiology of organisms on the composition of seawater, giving rise to the so-called 'Redfield-Ketchum-Richards (RKR) ratio' C/N/P = 106/1 $\mathrm{C}^{\prime}$ ' 1 . Towards the end of the 90 's the emphasis was shifted to the role of the envirnn ${ }^{\circ}$. it on the stoichiometry of

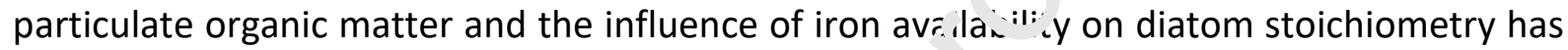
been widely recognized and elevated at the parad'gm 'evel (Hutchins and Bruland, 1998; Takeda, 1998; Hoffmann et al., 2007; Baines et al., 201 !. Following this paradigm, diatoms growing in Fe-depleted HNLC waters should hav hi', her (2-3 times) Si:C and Si:N ratios when compared to some empirical values ( $\because: \mathrm{C}=0.13, \mathrm{Si}: \mathrm{N}=1.12$ ) determined by Brzezinski (1985), which is supposed to indicate the 'evelopment of more heavily silicified diatoms. Nevertheless, lower Si content relat: $: 2$ tu $\mathrm{C}$ and $\mathrm{N}$ under high iron conditions can be linked

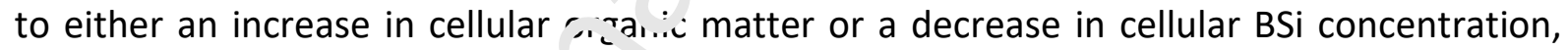
highlighting the species-specifi : re_ponse to iron enrichment (Takeda, 1998; Twining et al., 2004; Hoffmann et al., 2077; เ aines et al., 2011). Finally, a few studies pointed out that elemental ratios are 1 rim, rily driven by taxonomic composition of resident diatom communities rather than $\exists$ short term physiological response to iron addition (Hoffmann et al., 2006; Baines et al., 2010; Closset et al., 2014; Lasbleiz et al., 2014), again highlighting the primary role played by phytoplankton community structures in driving the biogeochemical cycles.

In our study, mixed layer Si:C and Si:N ratios in the bulk particulate matter (Figure 5) were close to the empirical values of Brzezinski (1985) at M1/M2/M3 (0.11-0.20 and 0.65-1.16, respectively) while they were significantly higher at the HNLC reference station M4 (0.520.59 and 3.36-3.66, respectively), which at first sight could indicate the presence of more heavily silicified diatoms. However, care should be taken when drawing conclusions about 
the diatom silicification degree based solely on particulate matter ratios. Indeed, these ratios result from the net effect of species-specific Si:C and Si:N composition (Sackett et al., 2014), subsequent species-specific mortality pathways, diatom contribution to particulate organic matter and the presence of detrital particulate Si.

Further insight can be gained by looking at a $\mathrm{Si}: \mathrm{C}_{\text {diatom }}$ ratio (Figure 11) based on calculated diatom carbon biomass rather than the bulk POC measurements, which include both autotrophic and heterotrophic biomass as well as phytodetritus and faecal pellets. Since other organisms bearing siliceous skeleton like rhizarians or : ilicoflagellates were negligible compared with diatoms in our study, this ratio is more repr $=x$ ntative of diatom elemental Si:C ratios although it is still subject to overestimation rec.use it includes detrital diatom fragments within BSi (average: $33 \pm 7 \%$ of broke..'empty/crunched frustules without considering smaller unidentifiable fragments). In ti. $M$., Si: $C_{\text {diatom }}$ ratios (>0.4) were well above the empirical value of 0.13 (Brzezinski, 19or) at all stations. Such elevated ratios in the study area may be driven by the presence $c_{i}$ dt... tal fragments of heavily silicified species (see supplementary Figure S6), such as nor coming from Fragilariopsis cells at M1/M3/M4 and Thalassionema nitzschioides at 12 . It is also plausible that Southern Ocean diatoms have $\mathrm{Si}: \mathrm{C}$ ratios higher than Brzezin $\mathrm{ki}$ ' s smpirical value, which was obtained from temperate and tropical species cultivated uncir nutrient-replete conditions. Indeed, recent studies indicate that polar diatoms Si:L ratios could reach values up to 0.87 (Lomas et al., 2019) and Southern Ocean species cou'd se 11-fold more silicified than diatoms cultured in nutrient replete conditions ( $\mathrm{B}_{\mathrm{i}} \mathrm{n}_{\mathrm{t}}-\mathrm{e}^{+}$al., 2010). This is to be compared with the results of Quéguiner and Brzezinski (2002) w'h, reported Si:C production ratios ranging between 0.54-1.19 at the onset of a diatom bloom in the polar frontal zone of the Atlantic sector. During KEOPS, Mosseri et al. (2008) also measured higher $\mathrm{Si}: \mathrm{C}$ and $\mathrm{Si}: \mathrm{NO}_{3}$ elemental uptake ratios in $\mathrm{HNLC}$ waters in comparison with Fe-fertilized waters, which they suggested was attributable to the development of more heavily silicified diatoms.

The Si: $\mathrm{C}_{\text {diatom }}$ ratios outside the plateau (average: 1.2-3.6) were much higher than over the plateau (average: 0.4-0.9). Based on PDMPO single-cell analysis (Figure 12), our data suggest that these differences are related to Southern Ocean diatom specificities. Within a given taxon (e.g. Fragilariopsis spp., Actinocyclus/Thalassiosira spp.), active diatoms were more 
heavily silicified outside the plateau at M1/M4, which supports the classical view that iron limitation leads to higher silicification degree and Si:C ratios (Hutchins and Bruland, 1998; Takeda, 1998; Hoffmann et al., 2007; Baines et al., 2010). However, the elevated Si:C $C_{\text {diatom }}$ ratios at M3 were also most likely driven by community differences, with the presence of smaller diatoms (e.g. Fragilariopsis pseudonana) known to be heavily silicified and with low C content due to their small biovolume, a characteristic which would therefore be added to the physiological response to iron stress (Marchetti and Cassar, 2009). Hence, regardless of the effects of iron on diatom physiology, the community composition itself strongly drives community silicification and elemental ratios. Heavily silicifie I Fragilariopsis frustules were numerous outside the plateau, while they were absent $w$ un ine $M L$ at $M 2$ where we observed many weakly silicified Corethron inerme fiu_tures. Discrepancies between elemental ratios in the bulk particulate matter and $\therefore$ diatoms can be attributed to the contribution of non-diatom components to total PC - As an illustration of this, the very low diatom contribution to total POC at $M 3$ tend=d to attenuate the diatom signal, which resulted in low Si:C and low Si:N ratios in the wulk particulate matter, similar to those measured above the plateau, although c 'at', m elemental ratios were much more elevated at M3.

The combination of our $m \in$ asu - oments integrating biogeochemical analyses, fine microscopic observations of the state of diatoms, and their silicification activity measured by the PDMPO method then :Ig gest that the higher diatom elemental ratios outside the plateau were likely $\mathrm{I}^{\mathrm{l} a \mathrm{a}} \mathrm{d}$ : o the combined effects of both taxonomic composition and a direct physiological rern',nse to iron stress, with key taxa e.g. Fragilariopsis spp. driving ratios toward elevated values. The response to iron stress is therefore a complex process integrating both the selection of dominant species which are particularly silicified and an ecophysiological response via the slowing down of their cell cycles.

\subsection{Ecological dynamics and the seasonal phytoplankton succession in the Kerguelen area}

Our statistical analysis revealed that depth was the main factor shaping diatom community structure, with one community roughly located within the upper mixed layer while a different one was systematically found within the pycnocline discontinuity (Figure 8). Spatial 
heterogeneity acted as a second factor separating on- versus off-plateau stations, hence, highlighting the role played by particular biogeochemical environments in structuring diatom communities (Lasbleiz et al., 2014; Lasbleiz et al., 2016).

Above the plateau, the mixed layer community was characterized by the presence of the large centric species Corethron inerme and Guinardia cylindrus ( $1^{\text {st }}$ visit only), in association with Thalassionema nitzschioides, Cylindrotheca closterium, and the centric genera Actinocyclus/Thalassiosira spp. Despite depleted $\mathrm{H}_{4} \mathrm{SiO}_{4}$ concentrations, C. inerme was actively growing as evidenced by an increase of its numeric al abundance, its silicification activity, and its contribution to diatom $C$ biomass. Interes. $-11 c^{-1} y$, this species has a small surface to volume ratio (Cornet-Barthaux et al., 2007), $v_{1}-\mathrm{n}$ would make it at first sight poorly adapted to low $\mathrm{H}_{4} \mathrm{SiO}_{4}$ environment. Based on . nicrocosm experiment, Brzezinski et al. (2011) showed that $\mathrm{Fe}$ and $\mathrm{Si}$ were associai $\mathrm{d} v$ ith two different biogeochemical pathways with high dissolved Fe increasing gr $\cdots$ th rates and organic matter production, especially of large diatoms, while $\mathrm{H}_{4} \mathrm{SiO}_{4}$ ava lati..... observations support the hypothesis t' 'at .he strong decoupling between organic matter production and silicification in diatoi. $` \varsigma$ (Paasche, 1973; Brzezinski et al., 1990; McNair et al., 2018) may allow the development $\mathrm{C}_{\mathrm{C}} \mathrm{l}_{\alpha} \cdot \sigma \mathrm{e}$ diatoms above the iron fertilized plateau, despite low $\mathrm{H}_{4} \mathrm{SiO}_{4}$ concentrations. By cr. ntr st, large and heavily silicified Eucampia antarctica cells were observed within the $p$,-nocline gradient in addition to small Chaetoceros spp. Hyalochaete vegetative stas ${ }^{\circ}$ and CRS; with the former species overwhelming diatom C biomass and likely $c^{-i v 1} \cdot \sigma$ the formation of the DSM. During KEOPS, at the end of the chlorophyll seasonal p\&al, a diatom community shift was observed, from one dominated by Chaetoceros spp. Hyalochaete to a new one dominated by E. antarctica in the upper $100 \mathrm{~m}$ (Armand et al., 2008b). Hence, put together, these data suggest a late seasonal stage marked by the replacement of E. antarctica by Corethron inerme in the upper mixed layer, $E$. antarctica persisting below the MLD until late February before progressively disappearing. By early March, at the very end of the growing season, small Chaetoceros spp. Hyalochaete and their CRS became the main contributors to both abundances and carbon biomass in the deep layer. CRS were previously observed below the pycnocline in spring (Lasbleiz et al., 2016) and mid-summer (Armand et al., 2008b), which supports the hypothesis of their yearround presence, enabling the species to bloom first with the onset of favorable conditions in 
spring (Lasbleiz et al., 2016). Resting spore formation is a strategy known to overcome unfavorable conditions such as low light levels (McQuoid and Hobson, 1996), macronutrients (Kuwata and Takahashi, 1990, 1999; Oku and Kamatani, 1995), or iron limitation (Sugie and Kuma, 2008). A recent study also showed that spores can be produced in nutrient-replete environments when a population reaches a threshold density and starts a process of selfremoval from the water column (Pelusi et al., 2020). In our study, $\mathrm{H}_{4} \mathrm{SiO}_{4}$ depletion characterizing end-summer conditions is the most likely factor involved in triggering resting spore formation.

Outside the fertilized plateau, the remote diatom commun' it: $o_{i}$ the $M L$ were very close with a dominance by Fragilariopsis species, Cylindrothe $\mathrm{u}$-losterium, and centric species belonging to the genera Actinocyclus and Thalassiosira. 1 common trait between off-plateau stations was the presence of Fragilariopsis kergu len is below the $\mathrm{ML}$, but its relative contribution was higher at M3 and M4, which son that it is considered as an indor of HNLC systems (Armand et al., 2008b; I.Isbicil et al., 2016). By contrast, within the pycnocline gradient, the two western riat Jm communities clustered separately from the eastern off-plateau community. The main differences were related to the dominance of Chaetoceros at/anticus on the west : $\mathrm{rr}$-ine, while it was virtually absent on the eastern side and replaced by CRS. The pre: enı? of the latter, known to characterize iron-fertilized systems (Abelmann et al., 200i; Armand et al., 2008b; Lasbleiz et al., 2016; Rembauville et al., 2016), tends to confirn, th th station M1 was at least partly influenced by the nearby plateau.

Three hypotheses can explain the presence of distinct diatom communities located either within the upper mixed layer or the pycnocline gradient: (1) the development of an active community supported by a deep nutricline, with diatoms adapted to low light levels (Crombet et al., 2011; Kemp and Villareal, 2013; Quéguiner, 2013), (2) the differential sinking and accumulation of diatoms from the overlying mixed layer (Quéguiner et al., 1997; Uitz et al., 2009), or (3) the selective grazing/parasitism. In a study similar to ours, investigating the link between microplankton community and particulate matter stoichiometry in the Kerguelen-Crozet region, Rembauville et al. (2016) suggested that high $\mathrm{Si}(\mathrm{OH})_{4}$ diffusive fluxes were likely to sustain silicification in the transition layer (i.e. defined 
as the interface between the stratified ocean interior and the highly turbulent surface mixed layer). Our incubation experiments with the fluorescent dye PDMPO showed on the contrary that silicification activity within the pycnocline gradient $(\geq 100 \mathrm{~m})$ was almost null, suggesting that deeper cells were not produced in situ, but rather originated from the overlying mixed layer. In particular, Eucampia antarctica cells and CRS observed above the plateau were not silicifying and likely corresponded to a remnant population that accumulated at the base of the mixed layer prior to the cruise. The relatively low percentage of crunched frustules ( $5 \pm 3 \%$ ) suggests that selective grazing had little impact on shaping communities, while parasites could have controlled populatic n dynamics prior to the cruise since elevated relative abundances of free Syndiniale, -oures was suggested by environmental sequencing (Sassenhagen et al., 2020). 'it. re, we argue that the density gradient acted as a strong physical barrier to sinking $w_{\text {: }}^{\text {th }}$ variable impacts on species. Light species (e.g. Cylindrotheca closterium, Corethron : err ie, small Fragilariopsis spp.) were efficiently recycled in the $M L$ and could not b. $r$ ass the density gradient, whereas denser ones (e.g. Fragilariopsis kerguelensis, Eucamr.ia u....arctica, Chaetoceros atlanticus, CRS etc.) rapidly settled out of the mixed laye: ar $d$ accumulated in the pycnocline, leading to a vertical structure of diatom communi-ies.

\subsection{Differential impact ol c'ia om species on Si/C export}

Past studies in naturally and Irtirıially Fe-fertilized systems have shown the central role played by phytoplankton comı unity structure in carbon vs. silica export, advocating the need for a species-cent rea approach to understand the fine dynamics of biogeochemical fluxes (Smetacek et al., 2004; Salter et al., 2012; Assmy et al., 2013; Quéguiner, 2013; Rembauville et al., 2015b, 2016). While Assmy et al. (2013) coined the terms "Si sinkers" and "C sinkers" to characterize the roles of individual species in the coupling/uncoupling of $\mathrm{Si}$ and C biogeochemical cycles, Quéguiner (2013) distinguished two types of more or less silicified diatom communities on the basis of their different ecological niches marked by a different seasonality.

In the present study, heavily silicified Fragilariopsis kerguelensis were mostly observed as empty frustules below the mixed layer ( $D$ :I ratio $>>2$ ), which explains their low contribution to $C$ biomass despite their high numerical abundances all over the study area. This species 
was identified as a strong Si sinker during EIFEX artificial fertilization experiment by Assmy et al. (2013) who reported a steady and downward flux of empty F. kerguelensis frustules, inside and outside the Fe-fertilized patch, associated with low-level, quasi-constant mortality. Indeed, F. kerguelensis frustules are thick and heavily silicified (Si:N ratios > 4:1) (Hamm et al., 2003; Hoffmann et al., 2007; Wilken et al., 2011), which has led to the hypothesis of a coevolution with copepods to withstand grazing pressure (the "arms race" Smetacek et al., 2004). Unexpectedly and contrary to the conceptual approaches of Assmy et al. (2013) and Quéguiner (2013), we observed many crunched Fragilariopsis kerguelensis frustules (average per station: 9-20\%) as well as cope; rod faecal pellets containing fragmented frustules (see supplementary Figure S9) which ir.ui ates that Fragilariopsis cells had been processed by copepod mandibles. In addition, ' ve רIso frequently observed whole F. kerguelensis cells inside phaeodarians belonging to the genus Protocystis spp. (e.g. P. swirei, P. harstoni, P. tridens; see supplementary : gur : S9), which is consistent with the results of González (1992) who found Fragilar: $n$ nsis as the most frequent diatom genus present in phaeodarian minipellets in sprinc in : ile Weddell-Scotia confluence. Selective grazing on $F$. kerguelensis likely increase $\mathrm{d} t \mathrm{t}$.e number of detrital cells, enhancing the sinking of Si relative to $\mathrm{C}$. The preferential -xportation of $\mathrm{Si}$ over other nutrients by thick-shelled empty frustules then strongly fue S ine Si pump (Dugdale et al., 1995), explaining the extremely high Si:C and Si:N ratic. $\mathrm{w}$ ? report below the MLD. Our hypothesis is supported by a significant correlation betwee $\cap$ BSi:POC and D:I ratios (Spearman rank correlation: $n=64$, $\rho=0.67, \mathrm{p}<0.05)$, and the much higher residual $\mathrm{NO}_{3}^{-}\left(>21 \mu \mathrm{mol} \mathrm{L}{ }^{-1}\right)$ relative to $\mathrm{H}_{4} \mathrm{SiO}_{4}$ (range: 1.7-6.9 $\mu \mathrm{mo},{ }^{1-}$, cr. .centrations in the surface layer. Outside the plateau, the Si pump was obviously mar - efficient due to (1) the higher proportion of F. kerguelensis below the $M L$, and (2) the physiological response to iron stress further increasing their silicification degree. Our results are similar to those from Rembauville et al. (2016) who showed that Southern Ocean transition layers (i.e. the pycnocline gradient) are key areas of $\mathrm{C}$ and $\mathrm{Si}$ decoupling where empty diatom frustules mainly from F. kerguelensis and Pseudo-nitzschia accumulate. During austral summer, at the peak of the plateau bloom development, Mosseri et al. (2008) also demonstrated that both the Fe-fertilized plateau and surrounding Fedepleted waters behaved as Si pumps but based upon different mechanisms with contrasted intensities. In the HNLC area, the Si pump was mainly driven by the development of more heavily silicified diatoms, whereas above the Kerguelen Plateau, the Si pump was mainly 
driven by the preferential degradation of soft organic matter over BSi dissolution. Apart from F. kerguelensis, several taxa such as Actinocyclus/Thalassiosira spp., Pseudo-nitzschia spp., and Chaetoceros atlanticus displayed D:I ratios $>2$, although their influence on the Si pump was probably weaker. By contrast, Chaetoceros spp. vegetative stages and CRS displayed D:I ratios $<0.5$, indicating that many cells were still intact below the mixed layer. Heavily silicified CRS can contain up to 10 times more carbon than the vegetative forms (Kuwata et al., 1993), have no vacuole and are rich in lipids and carbohydrates (Doucette and Fryxell, 1983; Kuwata et al., 1993), which make them efficient vectors for C and Si export. Above the plateau, CRS were abundant below the ML (Figure 8 ) and were associated with a quasi constant $C$ biomass between 100 and 200 m (Figurf $u$; suggesting they efficiently bypassed the pycnocline discontinuity and carried $C$ to rec ner layers. These results are in line with sediment trap and surface-sediment core stuc ies, which have reported CRS as one of the main vector of carbon export in naturally iror, fert lized systems, in particular over the Kerguelen Plateau and downstream of South Ge=moia where they can contribute to $42-52 \%$ of the annual POC fluxes (Armand et al., 20r 8 a, .embauville et al., 2015b, 2016, 2018). In our study, Eucampia antarctica D:I rat: $f f$.I between the thresholds $>0.5$ and $<2$ at M2-1, meaning the species was almost equ .lly represented by intact and detrital cells below the ML. Nevertheless, it was likely an In ir r rtant vector of carbon export, since most of the diatoms sampled by the Bottle-Net ¿'vice belonged to this species ( $47 \%$ within the $100-450$ $\mathrm{m}$ layer; Leblanc et al., in pres; During the naturally iron-fertilized Crozet bloom (CROZEX project), a significant posi.ivf relationship was reported between POC fluxes and $E$. antarctica by sedime, $+t_{1} \neg D_{c}$ deployed at $2000 \mathrm{~m}$, highlighting the importance of this species for carbon export (Saltır „t al., 2012). Hence, our data show that some species were able to efficiently bypass the pycnocline and to carry $\mathrm{C} / \mathrm{Si}$ to the ocean twilight zone. Through their physiological state, life stages, and selective grazing by micro/mesozooplankton, they can influence the efficiency of the export, as well as the properties of the sinking particles.

\section{Conclusion}

Our ability to predict the future role of the ocean in modulating the global $\mathrm{C}$ cycle and ultimately controlling the evolution of global climate depends on our understanding of the functioning of the biological carbon pump. The latter still presents major gaps, especially in the knowledge of the relationships that exist between the oceanic biodiversity and the 
efficiency of carbon transfer to deep layers, which is partly reflected by the relative utilization of associated elements, in particular N and $\mathrm{Si}$ in the Southern Ocean. During the MOBYDICK expedition, south of the Kerguelen Islands, we studied the processes linking diatom diversity with biogeochemistry, at several contrasted sites differently impacted by iron availability. Outside the iron-fertilized plateau, iron stress led to the selection of more heavily silicified taxa while a direct response to iron stress further increased the silicification degree of these selected diatoms. This affected the properties of the bulk particulate matter, which was characterized by higher elemental Si:C and Si:N ratios when compared to the plateau. Upper mixed layer diatom communities were clearly lifferent between on- and offplateau stations. Above the plateau, large and weakly silicifi $=u$ Corethron inerme were able to grow despite low silicic acid concentrations $\left(<2.7 \mu \mathrm{mo}^{\prime} L^{-1} !\right.$ ? cnaracteristic of the end stage of phytoplankton development, accompanied with Ac: :nocyclus/Thalassiosira spp. and the pennate species Thalassionema nitzschioides and $C$, 'ind otheca closterium. In HNLC waters, the diatom community was different and m=inly composed of Fragilariopsis species, Cylindrotheca closterium, and the centric cenc.d Actinocyclus/Thalassiosira spp. Beside horizontal spatial heterogeneity, dept' t $t$.rned out as an important parameter shaping diatom communities, since a deep and inacrive community associated with the pycnocline gradient was systematically observ : $d$ - $r$ rrying organic matter $(C, N)$ and biogenic minerals (Si) below the mixed layer. In nartı'llar, outside the plateau, the heavily silicified species Fragilariopsis kerguelensis carı. d mostly Si since it was largely found as detrital frustules, this being partly caused $b$; a strong grazing pressure by micro- and mesozooplankton. Conversely, above í: la la $2 a u$, many Eucampia antarctica and Chaetoceros spp. cells (resting spores and vegot גtive stages) were still intact below the mixed layer, hence carrying both $\mathrm{Si}$ and $\mathrm{C}$ to the deeper layers.

Our study highlights the importance of species-specific properties (e.g. morphology, silicification degree, carbon content, etc.), along with their physiological state (here related to iron availability), their life stages, and entire ecosystem trophodynamics including selective grazing in determining the efficiency of the export and the biogeochemical properties of exported particles, as emphasized by Tréguer et al. (2018). In the context of a changing Southern Ocean (e.g. greening, acidification, etc.), we advocate for the need to develop more studies following a species centered approach, as well as assessing trophic 
interactions through trophodynamics (e.g. predation, parasitism, saprophytism, etc.) in order to finely resolved biogeochemical fluxes and their control mechanisms. This should help to extract synthetic descriptors to better constrain more complex biogeochemical models aimed at simulating more closely the biological pump of carbon under the perspective of global climate change.

\section{Acknowledgements}

We thank B. Quéguiner, the PI of the MOBYDICK project, for providing us the opportunity to participate to this cruise, the chief scientist I. Obernosterer al $d$ the captain and crew of the R/V Marion Dufresne for their enthusiasm and support inc ra during the MOBYDICKTHEMISTO cruise (https://doi.org/10.17600/18000403). iri: work was supported by the French oceanographic fleet ("Flotte océanographique $;$ : ançaıse"), the French ANR ("Agence Nationale de la Recherche", AAPG 2017 program, M:'BY[ ICK Project number : ANR-17-CE010013), and the French Research program of INSI ' INRS LEFE/CYBER (“Les enveloppes fluides et l'environnement" - “Cycles biogéochimiqu+s, c...vironnement et ressources").

\section{Conflict of interest}

We declare that all authors of this $r$ ar.c cript do not have any conflict of interest. 


\section{Figures}

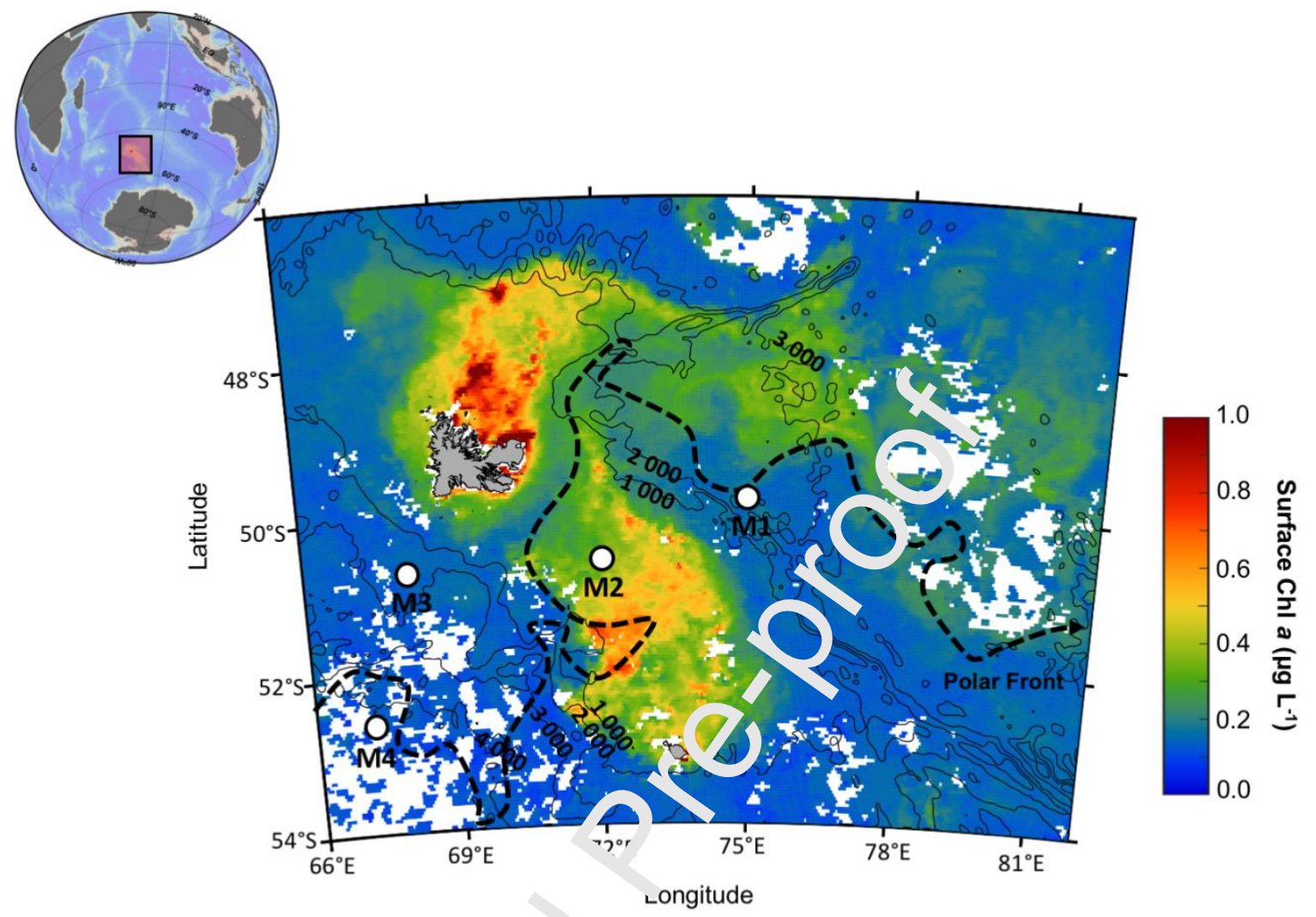

Figure 1. Location of the Kerguelen $\mathrm{Pl}_{\dot{4}}{ }^{+}{ }^{+} \mathrm{au}$ in the Indian sector of the Southern Ocean and detailed map of the satellite-deriv 1 surface chlorophyll $a$ concentration (MODIS level 3 product) averaged over Marc. 2018. The four stations sampled during MOBYDICK are indicated. Contour lines $r t_{1}$ re jent the bathymetry $(m)$. The dotted line represents the position of the Polar - ${ }^{-} \mathrm{O}$ + $+(\mathrm{P}:)$ ) according to Pauthenet et al. (2018). 


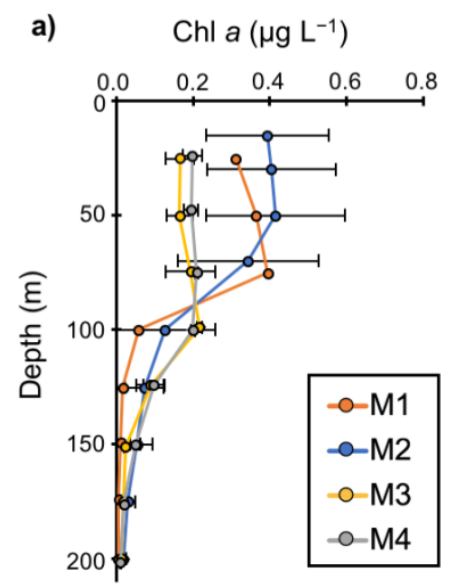

b)

$$
\mathrm{Si}(\mathrm{OH})_{4}(\mu \mathrm{mol} \mathrm{L}-1)
$$

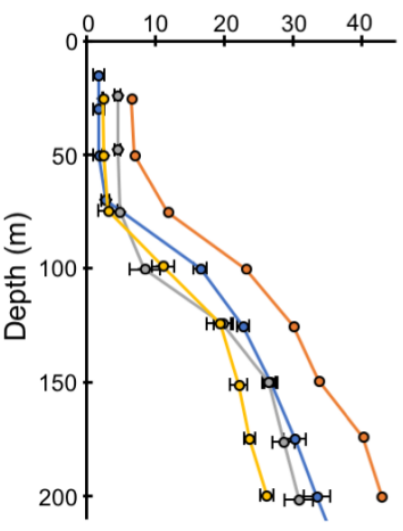

c) $\mathrm{NO}_{3}{ }^{-}\left(\mu \mathrm{mol} \mathrm{L}{ }^{-1}\right)$

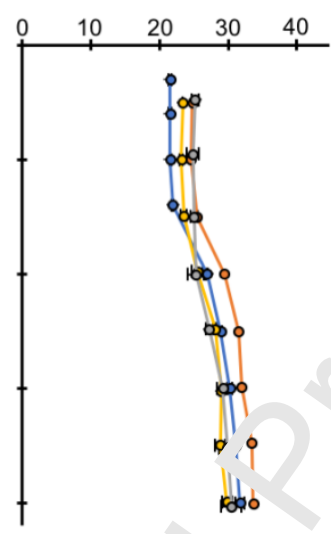

d) $\mathrm{PO}_{4}{ }^{3-}(\mu \mathrm{mol} \mathrm{I-1}$ e) $\mathrm{NH}_{4}{ }^{+}(\mu \mathrm{mol} \mathrm{L}-1)$

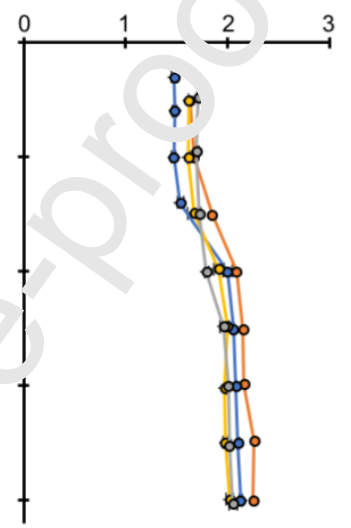

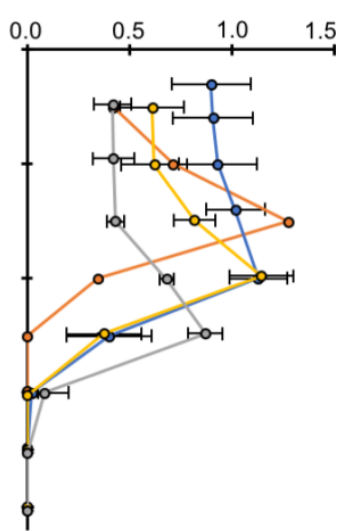

Figure 2. Average profiles of $\mathrm{Chl} \mathrm{a}^{-1}-1$ and nutrients (b-e) from several visits at the four stations. 

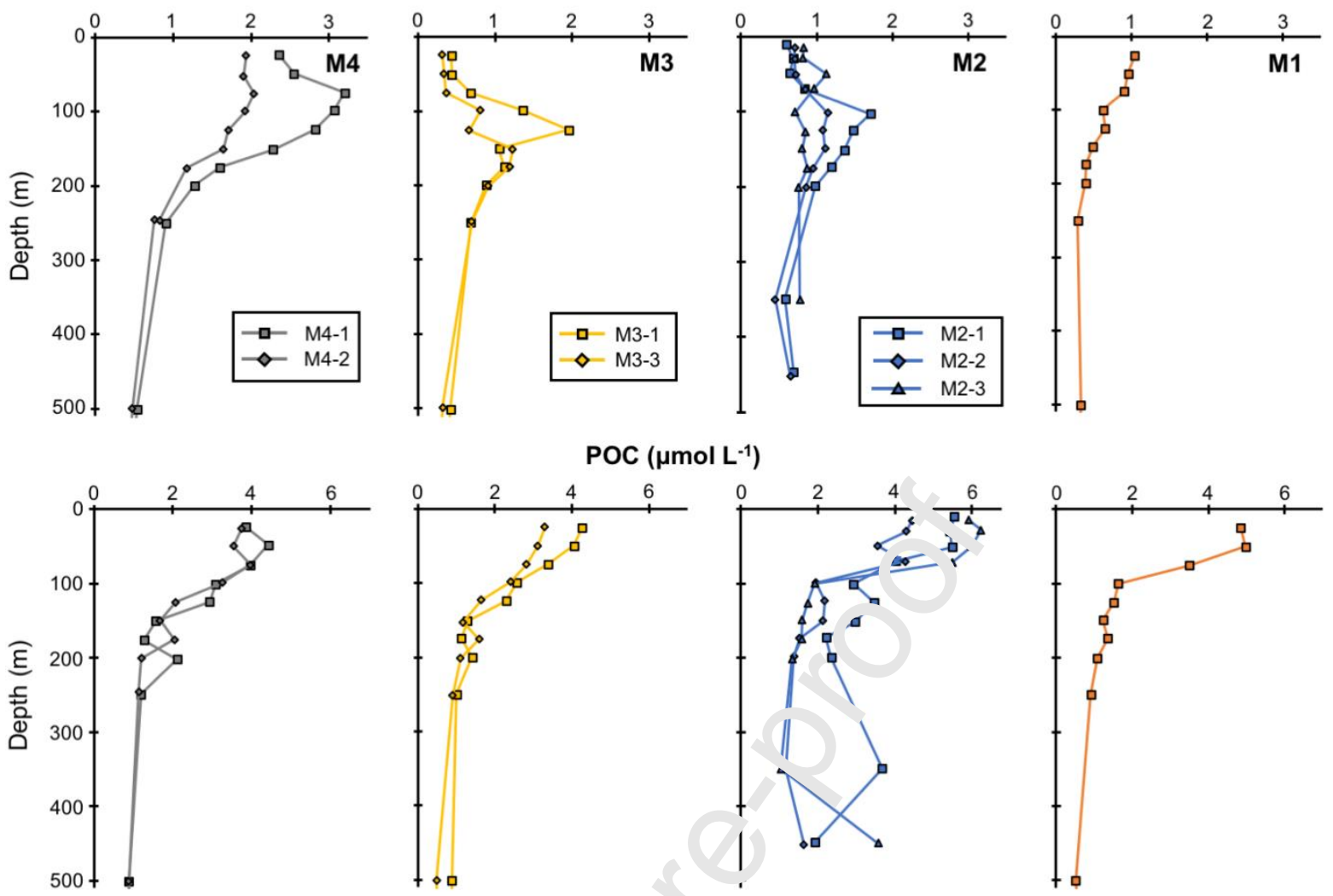

ON , $\left.\mu \mathrm{mol} \mathrm{L}^{-1}\right)$
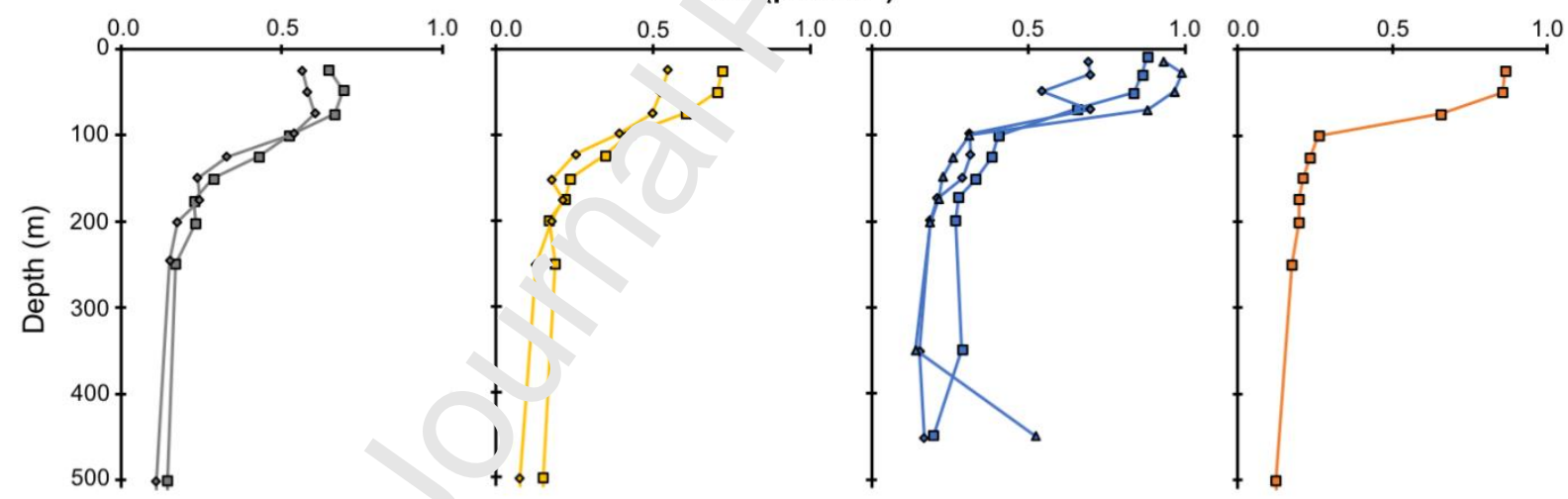

Figure 3. Vertical distrivution of biogenic silica (BSi), particulate organic carbon (POC), and particulate organic nitrogen (PON) at the four stations. Data are expressed in $\mu \mathrm{mol} \mathrm{L}^{-1}$. Symbols correspond to repeated visits to a same station. 

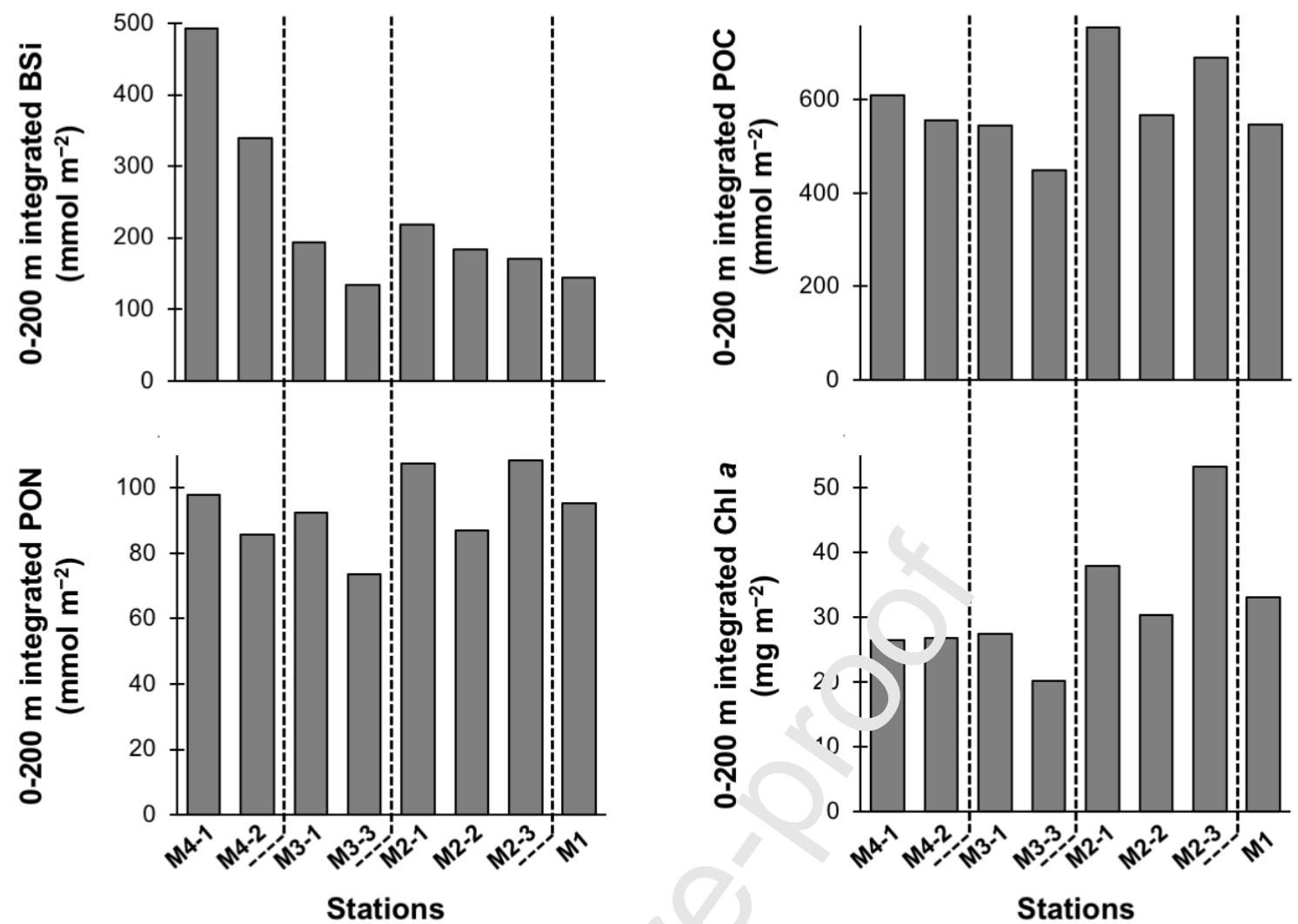

Figure 4. Integrated $\mathrm{BSi}, \mathrm{POC}, \mathrm{PON}$, and in $a$ usncentrations between 0 and $200 \mathrm{~m}$ at the four stations. 

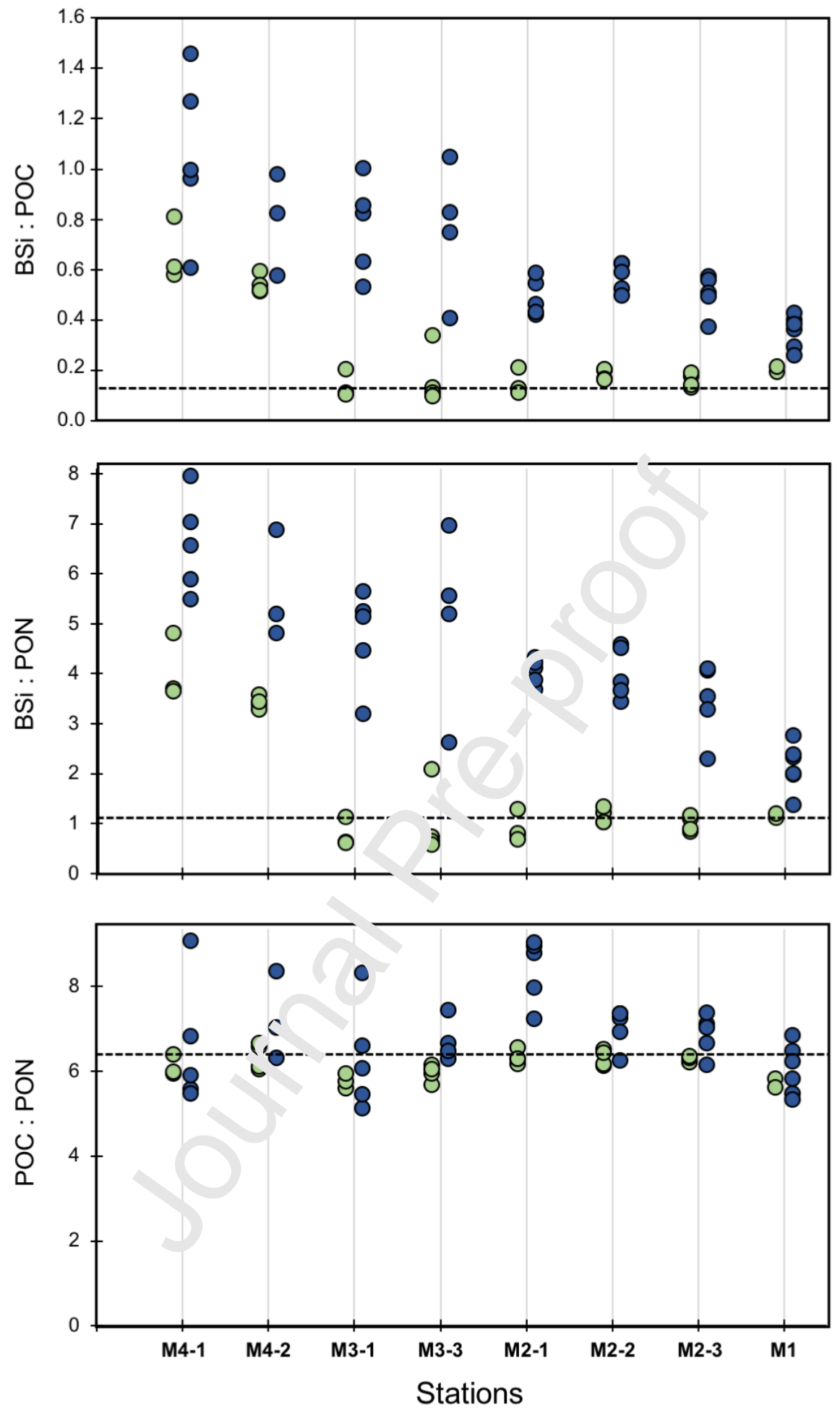

Figure 5. BSi:POC, BSi:PON, and POC:PON molar ratios based on the bulk of particulate matter between 0-MLD (green dots) and MLD-200 m (blue dots) at the four stations.

The black dashed lines represent the empirical values of Si:C (0.13), and Si:N (1.12) for nutrient-replete diatoms reported by Brzezinski (1985), as well as the typical value of C:N (6.6) reported by Redfield et al. (1963). 

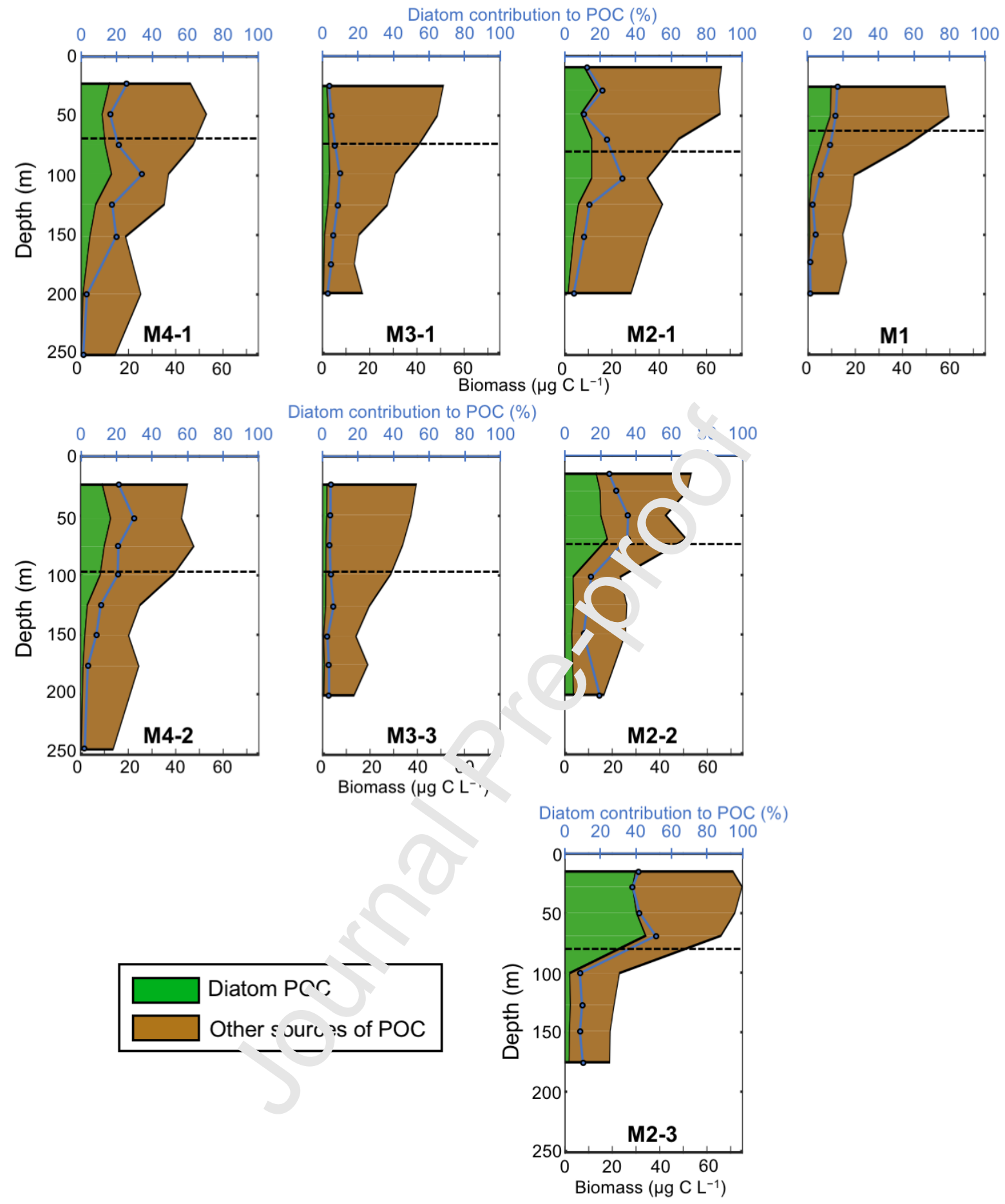

Figure 6. Absolute diatom $\mathrm{C}$ biomass and its contribution to POC.

Absolute diatom carbon biomass (green area) and other sources of POC (brown area). The sum of the green and brown areas gives the total POC. Data are expressed in $\mu \mathrm{g} \mathrm{C} \mathrm{L}^{-1}$. Blue dots indicate the diatom contribution to total POC (in percent). The dashed line indicates the location of the mixed layer depth (MLD). 

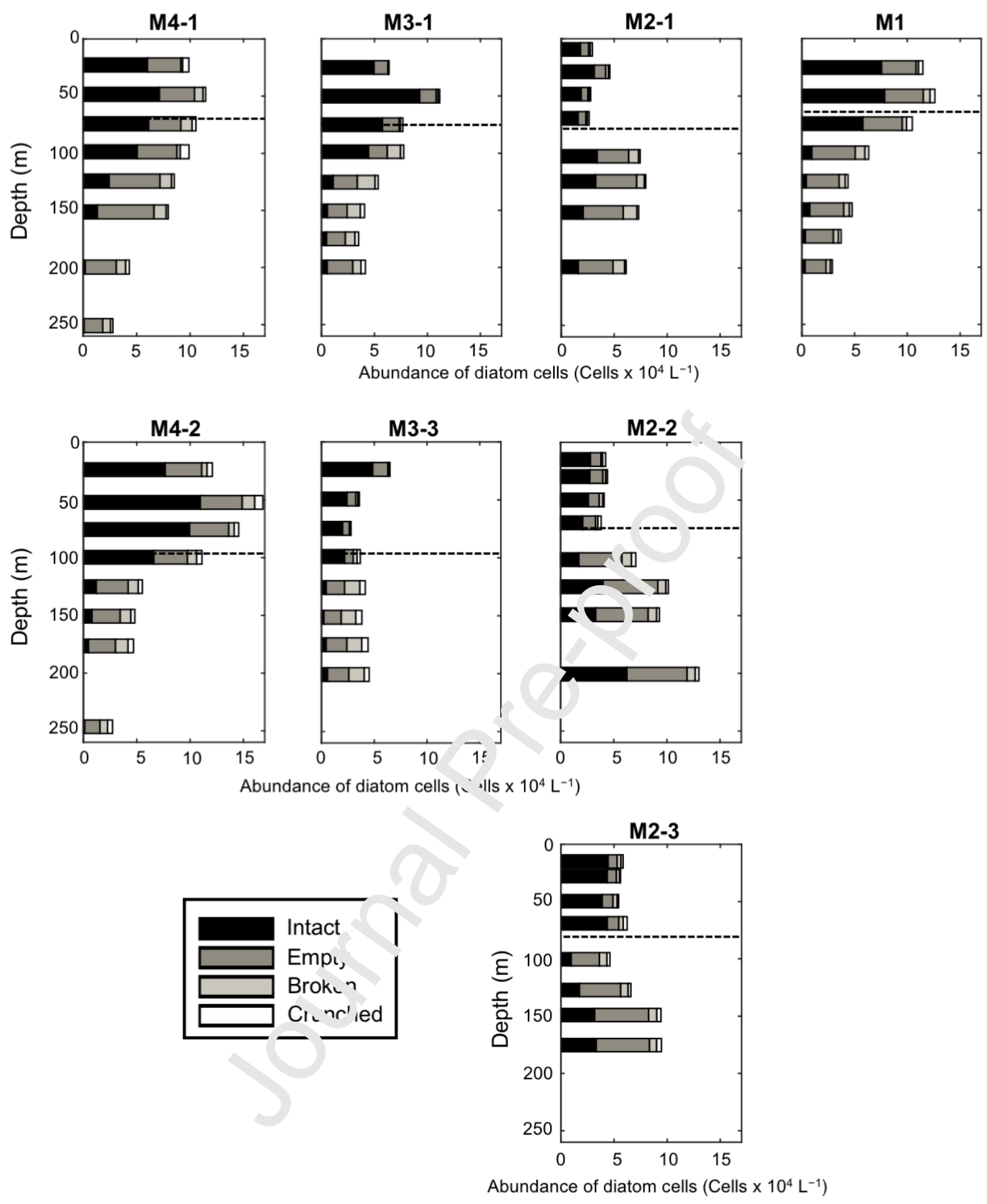

Figure 7. Vertical distribution of intact and detrital (i.e. empty, broken, and crunched) frustule abundances.

The dashed line indicates the location of the MLD. 


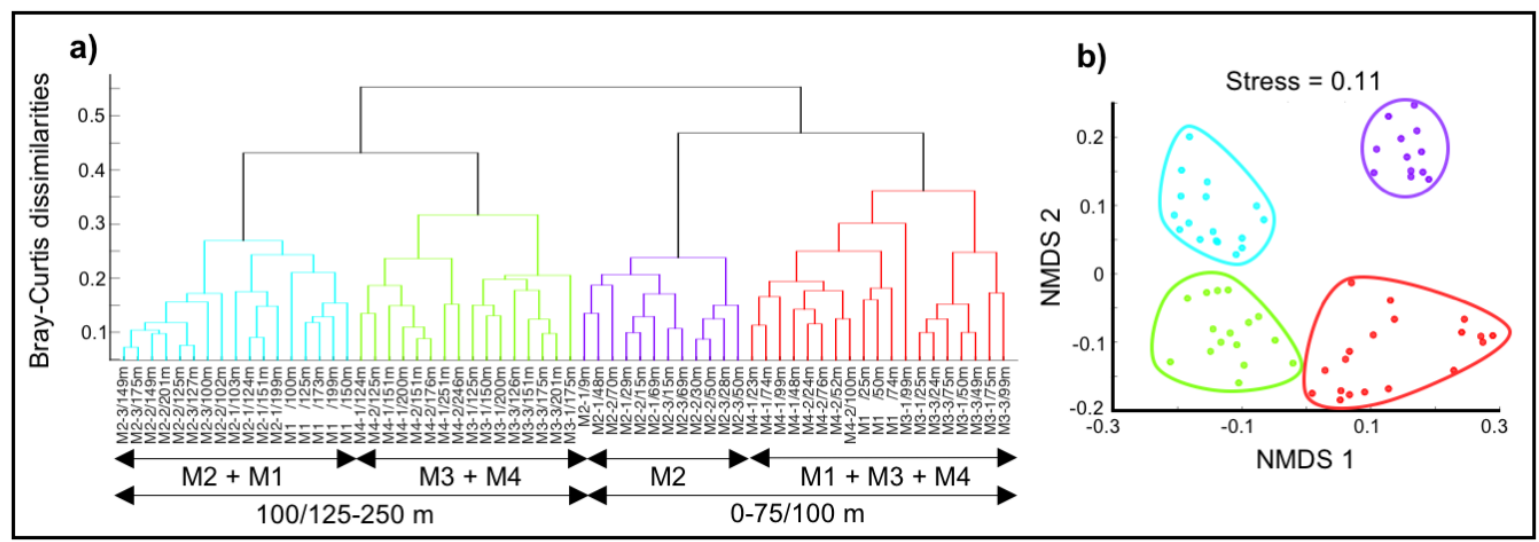

c)
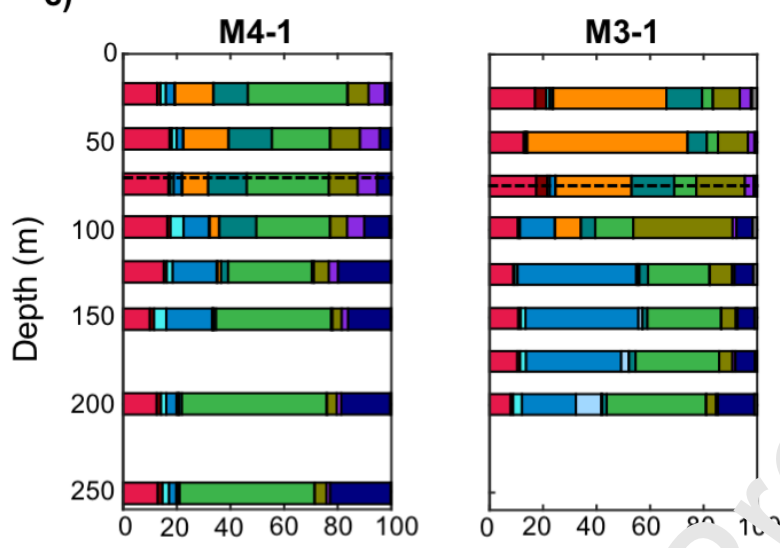

M2-1
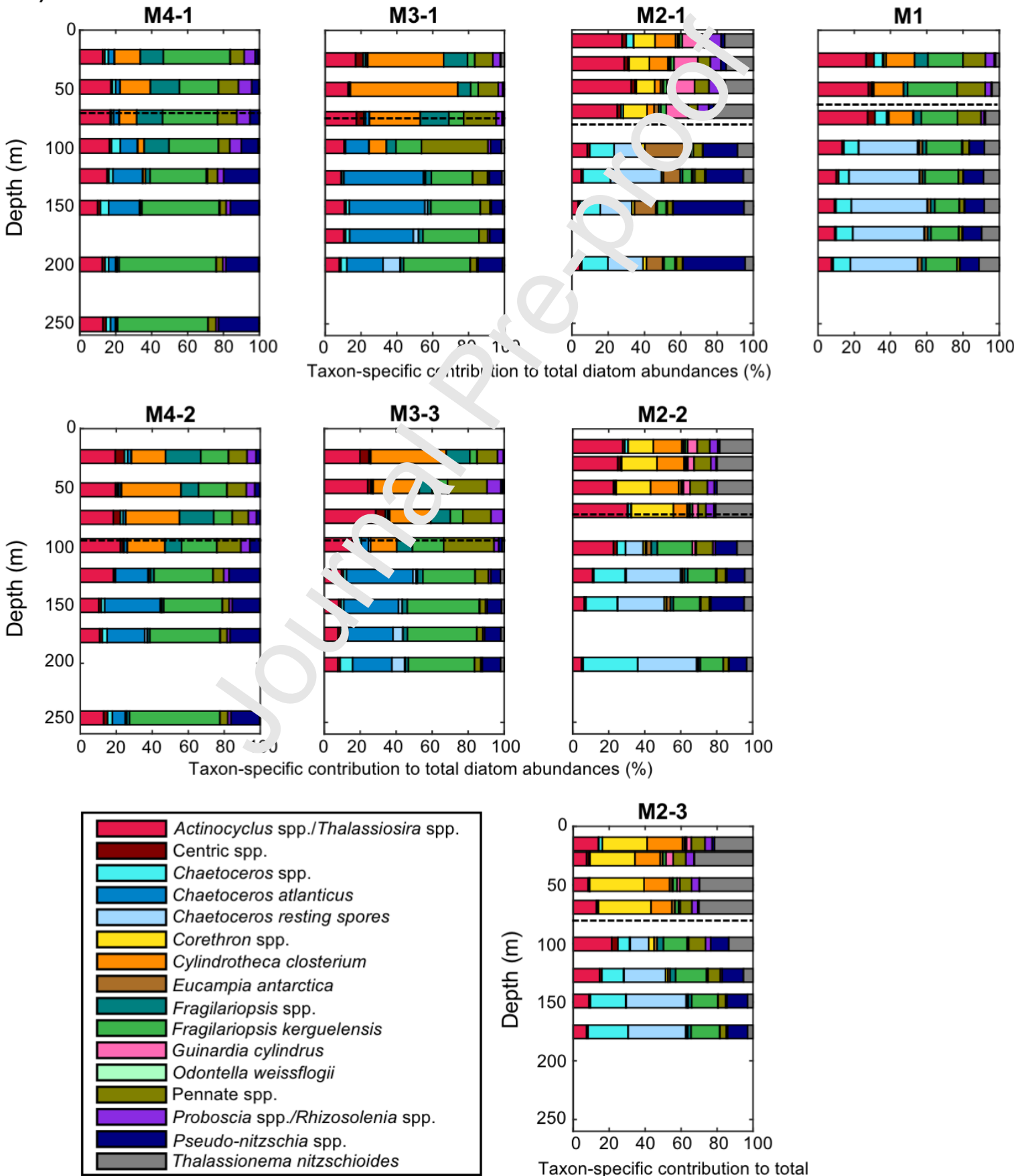

M2-2

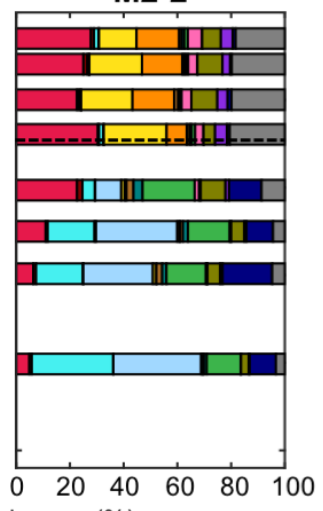

M2-3

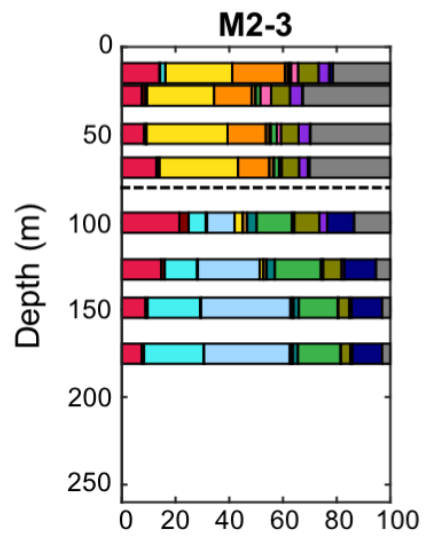

Taxon-specific contribution to total diatom abundances $(\%)$ 
Figure 8. Community structure and taxon-specific contribution to total diatom abundances.

(a) Cluster analysis performed on log $(x+1)$ abundances. The dendrogram displays the similarity relationship among samples in terms of their taxonomic composition. (b) Nonmetric multidimensional scaling (NMDS) ordination plot. Stations are coloured according to the cluster they belong to. (c) Taxon-specific contribution to total diatom abundances. Total abundances include both intact and detrital cells. Taxa are mutually exclusive, e.g. Chaetoceros spp. include all Chaetoceros species, excluding C. atlanticus and CRS. The dashed line indicates the location of the MLD. 

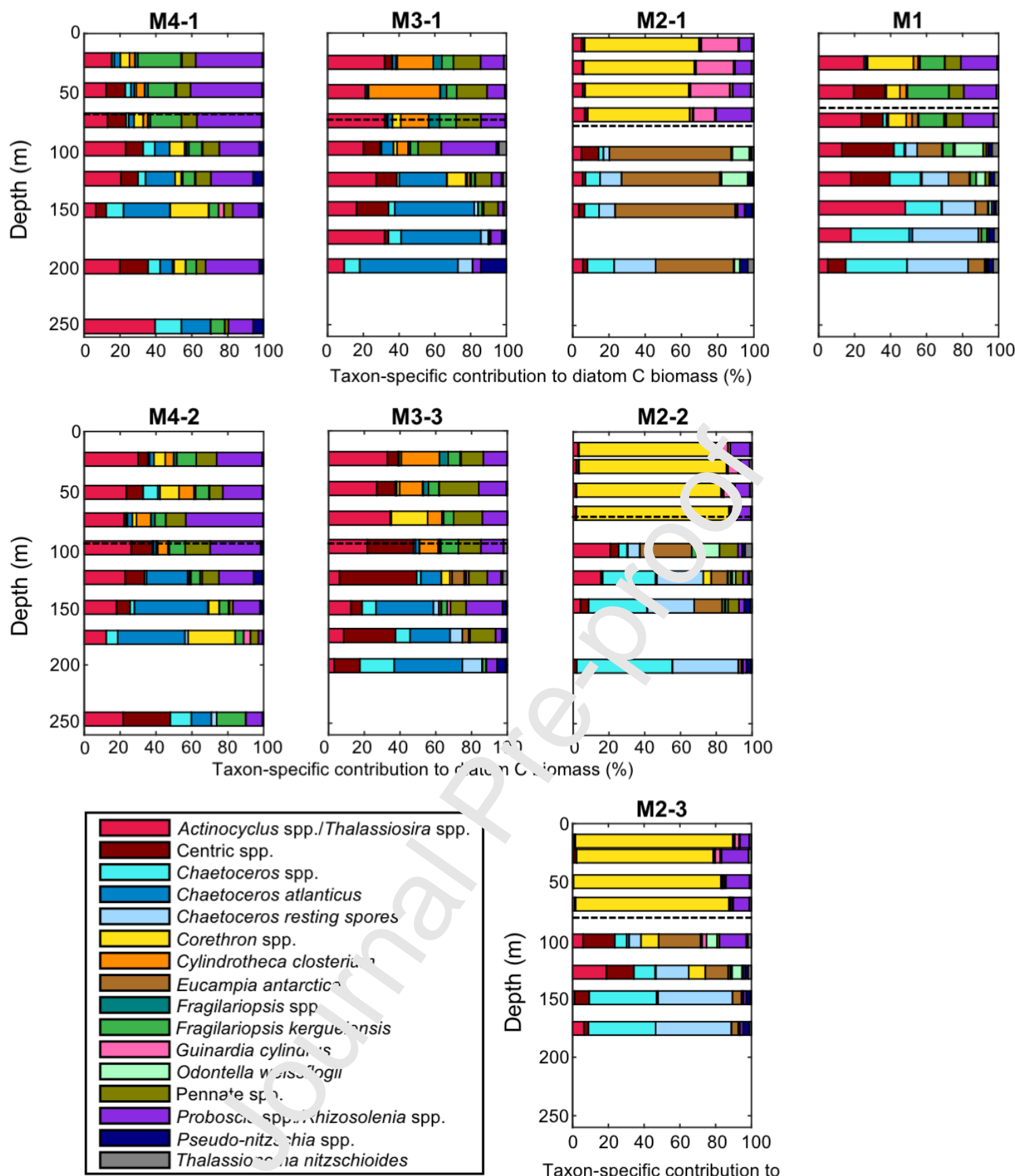

Taxon-specific contribution to diatom $\mathrm{C}$ biomass (\%)

Figure 9. Taxon-specific contribution to diatom carbon biomass.

The dashed line indicates the location of the MLD. 

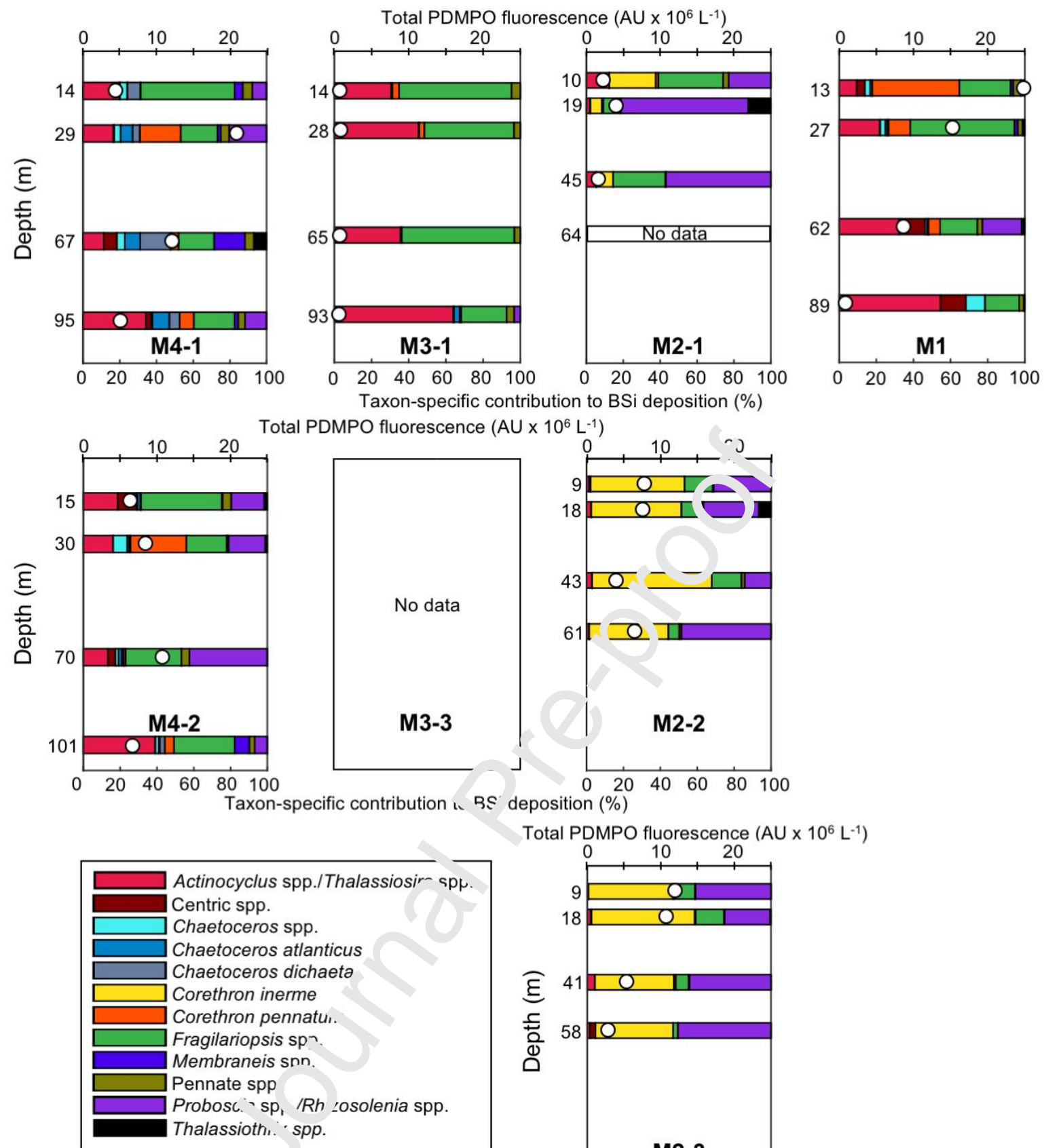

Total PDMPO fluorescence $\left(\mathrm{AU} \times 10^{6} \mathrm{~L}^{-1}\right)$

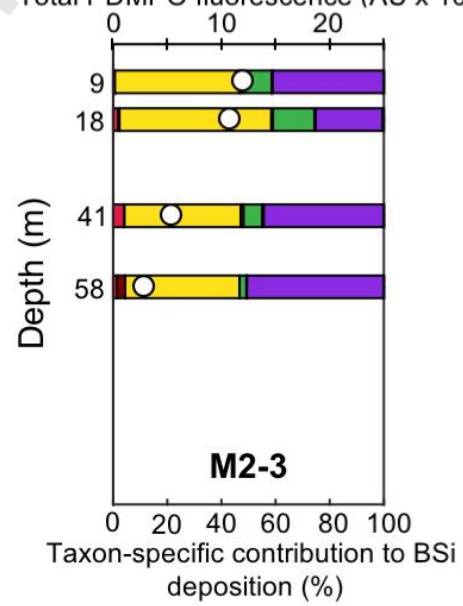

Figure 10. Community silicification activity and taxon-specific contribution to biogenic silica deposition, based on PDMPO staining.

White dots correspond to the total PDMPO fluorescence $\left(A U \times 10^{6} \mathrm{~L}^{-1}\right.$ ), i.e. the sum of each taxa absolute fluorescence. Collection depths were adjusted to correspond to simulated irradiance depths, which were equal to $50 \%, 25 \%, 4 \%$, and $1 \%$ of the surface PAR. Samples collected deeper and incubated in the dark did not fluoresce and therefore are not presented. Colour code and taxa presented are intentionally different from Figure 8 and 9 to 
show taxa that were important contributor to BSi deposition, while they were not dominant to abundances and/or C biomass. No data are reported for station M3-3 due to technical problems during incubations. 


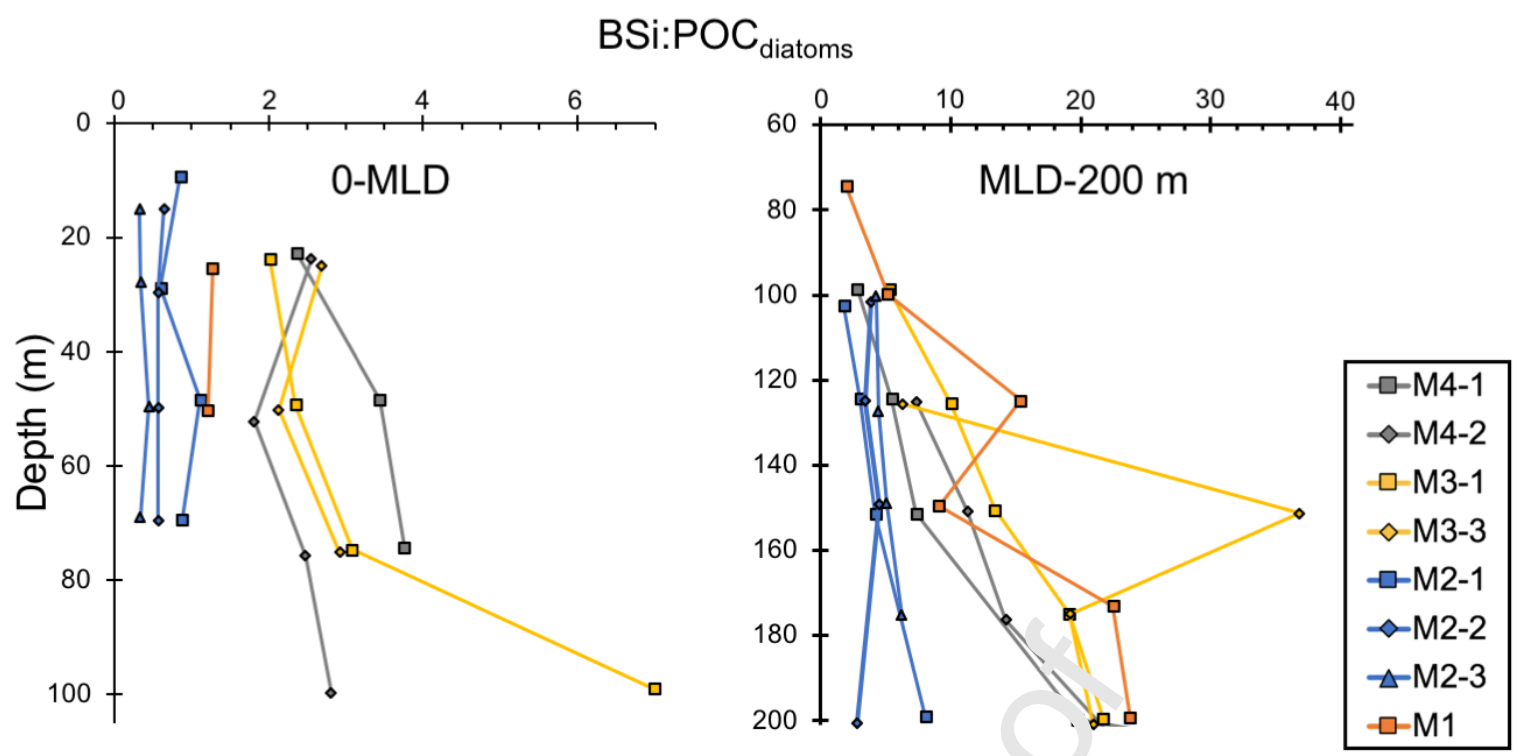

Figure 11. Vertical profiles of $\mathrm{Si}: \mathrm{C}_{\text {diatom }}$ ratios between 0-ı...D (left panel) and MLD-200 m (right panel). This ratio is based on calculated diatn $\mathrm{n}$ c, rbon biomass rather than the bulk POC measurements. 

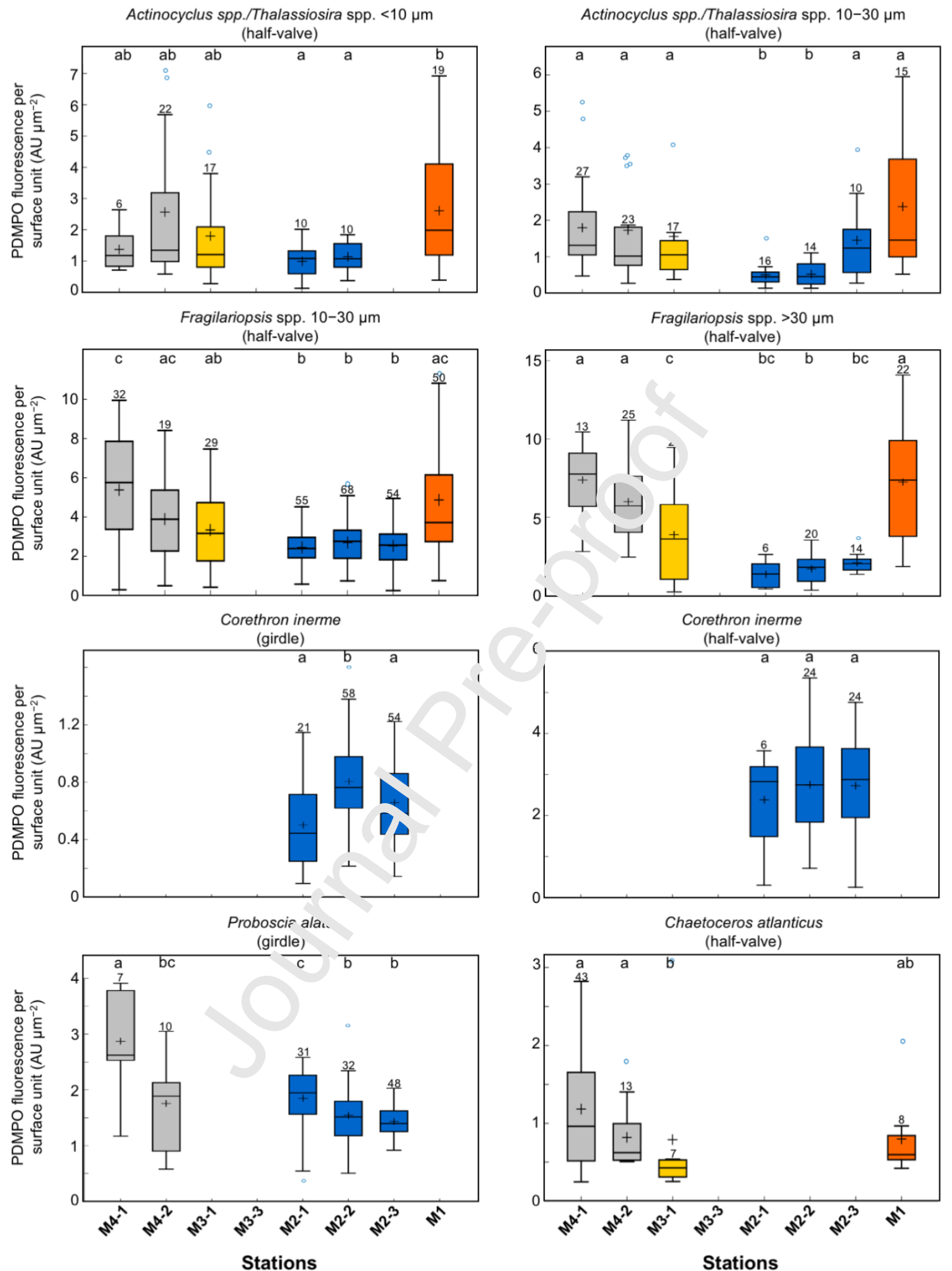

Figure 12. Silicification degree estimated through PDMPO staining.

Taxa presented are the most actively silicifying ones. The bottom and top edges of the box indicate the 25th and 75th percentiles, respectively. The line inside the box and the asterisk represent the median and the mean, respectively, and were calculated based on the data 
from all incubation depths. The vertical lines extend to the minimum and maximum values, while blue dots correspond to outliers. The number of observations for each box is indicated above the vertical line. Boxplot of which medians are not statistically different are indicated by the same letter (Mann-Whitney u test, $p>0.05$ ).

\section{Tables}

Table 1. Metadata and hydrographical conditions at stations sumpled during the MOBYDICK expedition.

\begin{tabular}{|c|c|c|c|c|c|}
\hline Station & Latitude/Longitude & Date & $\begin{array}{c}\text { Bot }+c \text { nd :pth } \\
(\mathrm{m})\end{array}$ & $\begin{array}{c}\text { MLD } \\
(\mathrm{m}) \\
\end{array}$ & $\begin{array}{c}\text { Ze } 1 \% \\
(\mathrm{~m})\end{array}$ \\
\hline M4-1 & \multirow{2}{*}{$52.60^{\circ} \mathrm{S}, 67.20^{\circ} \mathrm{E}$} & 01/03/2018 & \multirow{2}{*}{4731} & 69 & 95 \\
\hline M4-2 & & 12/03/2019 & & 96 & 101 \\
\hline M3-1 & \multirow{2}{*}{$50.68^{\circ} \mathrm{S}, 68.06^{\circ} \mathrm{E}$} & 04/03/2.)1c & \multirow{2}{*}{1730} & 74 & 93 \\
\hline M3-3 & & 19032018 & & 96 & 105 \\
\hline M2-1 & \multirow{3}{*}{$50.62^{\circ} \mathrm{S}, 72.00^{\circ} \mathrm{E}$} & $26 / 02 /<018$ & \multirow{3}{*}{520} & 79 & 64 \\
\hline$M 2-2$ & & ๙ $/ し 3 / 2018$ & & 73 & 61 \\
\hline M2-3 & & $10 / 03 / 2018$ & & 80 & 58 \\
\hline M1 & $49.85^{\circ} \mathrm{S}, 74.9 i^{\circ} \mathrm{E}$ & 09/03/2018 & 2723 & 63 & 89 \\
\hline
\end{tabular}




\section{Journal Pre-proof}

Table 2. Average detrital:intact frustules ratios (D:I) below the MLD. Number in brackets correspond to the standard deviations. "Ab" corresponds to the relative abundance averaged below the MLD. Bold numbers represent numerically dominant taxa below the mixed layer depth, i.e. with a relative contribution to total diatom abundances higher than $10 \%$.

\begin{tabular}{|c|c|c|c|c|c|c|c|c|c|c|c|c|c|c|c|c|}
\hline \multirow{2}{*}{ Species and genera grouping } & \multicolumn{2}{|l|}{ M4-1 } & \multicolumn{2}{|l|}{ M4-2 } & \multicolumn{2}{|l|}{ M3-1 } & \multicolumn{2}{|l|}{ M3-3 } & \multicolumn{2}{|l|}{ M2-1 } & \multicolumn{2}{|l|}{ M2-2 } & \multicolumn{2}{|l|}{$\mathrm{M} 2-3$} & \multicolumn{2}{|l|}{ M1 } \\
\hline & D:I & $A b$ & D:I & $A b$ & D:I & $A b$ & D:I & $A b$ & D:I & $A b$ & D:I & $A b$ & D:I & $A b$ & D:I & $A b$ \\
\hline Fragilariopsis kerguelensis & $58.6(71.3)$ & 41 & $51.1(35.3)$ & 39 & $64.5(55.7)$ & 27 & $221.8(57.5)$ & 36 & $63.6(79.5)$ & 4 & $96(84.7)$ & 16 & $113.4(81.7)$ & 15 & $134.2(126.8)$ & 17 \\
\hline Chaetoceros resting spore & $0.3(0.3)$ & 0 & $0.3(0.3)$ & 1 & $1.1(1.5)$ & 3 & $1.4(0.3)$ & 4 & $0.5(0.1)$ & 20 & . $4(0)$ & 25 & $0.7(0.1)$ & 25 & $7.5(1.4)$ & 32 \\
\hline Pseudo-nitzschia spp. & $34.2(44.2)$ & 17 & $74.6(97.8)$ & 16 & $6.2(4.5)$ & 8 & $9.4(3.2)$ & 8 & $13.3(3.9)$ & $2 f$ & $1.1(3.7)$ & 13 & $12.7(2.7)$ & 11 & $20.4(13.3)$ & 9 \\
\hline Actinocyclus/Thalassiosira spp. & $24.4(28.3)$ & 13 & $26.8(18.2)$ & 13 & $20.4(14.6)$ & 10 & $28(8.5)$ & 8 & $10.2(8.1)$ & 5 & $5.1(72.4)$ & 11 & $29.4(19.9)$ & 13 & $24.2(17.7)$ & 13 \\
\hline Chaetoceros atlanticus & $2.2(2.6)$ & 10 & $3.4(3.6)$ & 19 & $3.3(0.3)$ & 31 & $8.7(2.7)$ & 29 & $-(-1)$ & i & $1.2(0.7)$ & 0 & $2(1.7)$ & 0 & $1(0.5)$ & 0 \\
\hline Chaetoceros spp. & $1.9(2.2)$ & 3 & $0.5(0.3)$ & 2 & $0.8(0.6)$ & 2 & $0.7(0.2)$ & 3 & $n \in(L 1)$ & .4 & $0.4(0.1)$ & 17 & $0.5(0.1)$ & 15 & $1.1(0.7)$ & 8 \\
\hline Pennate spp. & $18.7(25)$ & 5 & $67(97.3)$ & 4 & $23.9(30.6)$ & 12 & $17.3(16.5)$ & 4 & $-4.9, ? 4)$. & 4 & $30.8(23)$ & 5 & $31(28.3)$ & 6 & $5.7(5.3)$ & 4 \\
\hline Thalassionema nitzschioides & $1.2(0.7)$ & 0 & $2.3(1.5)$ & 0 & $2.6(1.8)$ & 1 & $6.4(3.5)$ & 2 & $2(89)$ & 6 & $4.2(1.2)$ & 5 & $6.6(1.2)$ & 6 & $11(8.2)$ & 9 \\
\hline Eucampia antarctica & $-(-)$ & 0 & $-(-)$ & 0 & $0.1(0.1)$ & 0 & $0.4(0.2)$ & ? & $1 . \div(1.6)$ & 13 & $2.2(2.3)$ & 2 & $1.2(0.9)$ & 1 & $17.1(24.1)$ & 2 \\
\hline Fragilariopsis spp. & $12.9(20)$ & 4 & $18.4(8)$ & 1 & $11(13.4)$ & 3 & $621-$ & 2 & $28.1(24.4)$ & 1 & $51.6(25.9)$ & 2 & $59.8(56.9)$ & 3 & $8.7(6.8)$ & 2 \\
\hline Corethron inerme & $2.6(3.7)$ & 0 & $1.3(0.3)$ & 0 & $1.3(1.1)$ & 0 & $(-$, & u & $-(-)$ & 2 & $16.8(-)$ & 1 & $28.2(22.3)$ & 1 & $3.7(-)$ & 0 \\
\hline Cylindrotheca closterium & $0.9(1.4)$ & 1 & $1(1.4)$ & 0 & $0.4(0.5)$ & 2 & $r_{\perp}(0.1$ & 0 & $-(-)$ & 0 & $0.1(0.2)$ & 0 & $0(0)$ & 0 & $0(0)$ & 2 \\
\hline Proboscia/Rhizosolenia spp. & $2.6(2.4)$ & 3 & $4.1(2.1)$ & 2 & $2.8(2.3)$ & 1 & $3.9(0.9)$ & 1 & $5.4(2.7)$ & 0 & $5.6(0.9)$ & 1 & $5.4(2.8)$ & 1 & $9.6(7.2)$ & 0 \\
\hline Centric spp. & $11.8(14.5)$ & 1 & $12.3(14.5)$ & 1 & $11.6(17.1)$ & 1 & $\therefore 2(10.9)$ & 1 & $15.8(2.1)$ & 1 & $19.7(9.5)$ & 1 & $13.6(16.4)$ & 2 & $13.6(10.5)$ & 1 \\
\hline Guinardia cylindrus & $6(7.8)$ & 0 & $1.7(1.2)$ & 0 & $3(2.8$ & ८ & $3(2.8)$ & 0 & $8.3(7.4)$ & 1 & $6.9(4.7)$ & 1 & $6.6(5.1)$ & 0 & $1(1.4)$ & 0 \\
\hline Odontella weissflogii & $-(-)$ & 0 & $-(-)$ & 0 & $\therefore-1$ & J & $-(-)$ & 0 & $3.2(3.7)$ & 1 & $1.6(1.3)$ & 0 & $0.7(0.2)$ & 0 & $0.8(0.9)$ & 0 \\
\hline
\end{tabular}




\section{References}

Abelmann A, Gersonde R, Cortese G, Kuhn G, Smetacek V. 2006. Extensive phytoplankton blooms in the Atlantic sector of the glacial Southern Ocean. Paleoceanography 21(1): PA1013. doi: 10.1029/2005PA001199

Afnor, 2015. EN 16695. Water Quality - Guidance on the estimation of phytoplankton biovolume. Afnor, 1-109

Alldredge AL, Gotschalk CC. 1989. Direct observations of the mass flocculation of diatom blooms: characteristics, settling velocities and formation of diatom aggregates. Deep Sea Res Part Oceanogr Res Pap 36(2): 159-171. doi: 10.1016/0198-0149(89)90131-3

Alldredge AL, Jackson GA. 1995. Preface: Aggregation in m--int system. Deep Sea Res Part II Top Stud Oceanogr 42(1): 1-7. doi: 10.1016/0967-0645(95)90003-9

Aminot A, Kérouel R. 2007. Dosage automatiauc des ıutriments dans les eaux marines : méthodes en flux continu. Editions Quae, Ifremer, Bre + F ance, 189 pp.

Armand L, Crosta X, Quéguiner B, P 10. cerı J, Garcia N. 2008a. Diatoms preserved in surface sediments of the northeastern Kerg' 1 i i n i lateau. Deep Sea Res Part II Top Stud Ocean 55(5-7): 677692. doi: $10.1016 / j . d s r 2.2007 .12 \cdot 32$

Armand L, Veronique C-r, N. ssseri J, Quéguiner B. 2008b. Late summer diatom biomass and community structure on a.d around the naturally iron-fertilised Kerguelen Plateau in the Southern Ocean. Deep Sea Res Part I/ 55(5-7): 653-676. doi: 10.1016/j.dsr2.2007.12.031

Armstrong RA, Lee C, Hedges JI, Honjo S, Wakeham SG. 2002. A new, mechanistic model for organic carbon fluxes in the ocean based on the quantitative association of POC with ballast minerals. Deep Sea Res Part II Top Stud Oceanogr 49(1-3): 219-236. doi: 10.1016/S0967-0645(01)00101-1

Arteaga LA, Pahlow M, Bushinsky SM, Sarmiento JL. 2019. Nutrient Controls on Export Production in the Southern Ocean. Glob Biogeochem Cycles 33(8): 942-956. doi: 10.1029/2019GB006236

Assmy P, Henjes J, Klaas C, Smetacek V. 2007. Mechanisms determining species dominance in a 
phytoplankton bloom induced by the iron fertilization experiment EisenEx in the Southern Ocean. Deep Sea Res Part Oceanogr Res Pap 54(3): 340-362. doi: 10.1016/j.dsr.2006.12.005

Assmy P, Smetacek V, Montresor M, Klaas C, Henjes J, Strass VH, Arrieta JM, Bathmann U, Berg GM, Breitbarth E, et al. 2013. Thick-shelled, grazer-protected diatoms decouple ocean carbon and silicon cycles in the iron-limited Antarctic Circumpolar Current. Proc Natl Acad Sci 110(51): 20633-20638. doi: $10.1073 /$ pnas.1309345110

Baines SB, Twining BS, Brzezinski MA, Nelson DM, Fisher NS. 2010. Causes and biogeochemical implications of regional differences in silicification of marine diaton: Glob Biogeochem Cycles 24(4). doi: 10.1029/2010GB003856

Baines SB, Twining BS, Vogt S, Balch WM, Fisher NS, Nels: n Divi. 2011. Elemental composition of equatorial Pacific diatoms exposed to additions of silicic icid nd iron. Deep Sea Res Part II Top Stud Oceanogr 58(3-4): 512-523. doi: 10.1016/j.dsr2.2010.02.003

van Beek P, Bourquin M, Reyss J-L, Souhau'. MI Churette MA, Jeandel C. 2008. Radium isotopes to investigate the water mass pathways on the $k_{\llcorner}$-guelen Plateau (Southern Ocean). Deep Sea Res Part II Top Stud Oceanogr 55(5-7): 622-637. do. 10.1016/j.dsr2.2007.12.025

Blain S, Capparos J, Guéneuguès A, Jbernosterer I, Oriol L. 2015. Distributions and stoichiometry of dissolved nitrogen and phosph, $r_{\text {ru }}$ in the iron-fertilized region near Kerguelen (Southern Ocean). Biogeosciences 12(2): 623-625. Ir.: 10.5194/bg-12-623-2015

Blain S, Quéguiner B, Arm nd L, Belviso S, Bombled B, Bopp L, Bowie A, Brunet C, Brussaard C, Carlotti $F$, et al. 2007. Effect of natural iron fertilization on carbon sequestration in the Southern Ocean. Nature 446(7139): 1070-1074. doi: 10.1038/nature05700

Boyd PW. 2002. Environmental factors controlling phytoplankton processes in the Southern Ocean. J Phycol 38(5): 844-861. doi: 10.1046/j.1529-8817.2002.t01-1-01203.x

de Boyer Montégut C, Madec G, Fischer A, Lazar A, ludicone D. 2004. Mixed layer depth over the global ocean: An examination of profile data and a profile-based climatology. J Geophys Res Oceans 19782012 109(C12). doi: 10.1029/2004JC002378 
Brzezinski MA, Olson R, Chisholm S. 1990. Silicon availability and cell-cycle progression in marine diatoms. Mar Ecol Prog Ser 67: 83-96. doi: 10.3354/meps067083

Brzezinski MA. 1985. The Si:C:N ratio of marine diatoms: interspecific variability and the effect of some environmental variables. J Phycol 21(3): 347-357. doi: 10.1111/j.0022-3646.1985.00347.x

Brzezinski MA, Baines SB, Balch WM, Beucher CP, Chai F, Dugdale RC, Krause JW, Landry MR, Marchi A, Measures $\mathrm{Cl}$, et al. 2011. Co-limitation of diatoms by iron and silicic acid in the equatorial Pacific. Deep Sea Res Part II Top Stud Oceanogr 58(3-4): 493-511. doi: 10.1016/j.dsr2.2010.08.005

Buesseler KO. 1998. The decoupling of production and particulatf ex ort in the surface ocean. Glob Biogeochem Cycles 12(2): 297-310. doi: 10.1029/97GB03366

Burd AB, Jackson GA. 2009. Particle Aggregation Anı u Rev Mar Sci 1(1): 65-90. doi: 10.1146/annurev.marine.010908.163904

Closset I, Lasbleiz M, Leblanc K, Quéguiner B, Zavuzna A-J, Elskens M, Navez J, Cardinal D. 2014. Seasonal evolution of net and regenerated silı oroduction around a natural Fe-fertilized area in the Southern Ocean estimated with Si isotop:- approaches. 11(20): 5827-5846. doi: 10.5194/bg-11$5827-2014$

Cornet-Barthaux V, Armand L, C'ies 'iner B. 2007. Biovolume and biomass estimates of key diatoms in the Southern Ocean. Aqurt M: ${ }^{\prime r}$ ob Ecol 48: 295-308. doi: 10.3354/ame048295

Crombet Y, Leblanc K, Quẹg גiner B, Moutin T, Rimmelin P, Ras J, Claustre H, Leblond N, Oriol L, PujoPay M. 2011. Deep silicon maxima in the stratified oligotrophic Mediterranean Sea. Biogeosciences 8(2): 459-475. doi: 10.5194/bg-8-459-2011

Doucette GJ, Fryxell GA. 1983. Thalassiosira antarctica: vegetative and resting stage chemical composition of an ice-related marine diatom. Mar Biol 78(1): 1-6. doi: 10.1007/BF00392964

Dugdale RC, Wilkerson FP, Minas HJ. 1995. The role of a silicate pump in driving new production. Deep Sea Res Part Oceanogr Res Pap 42(5): 697-719. doi: 10.1016/0967-0637(95)00015-X 
gene transcription and the influence of diatom community composition on silica precipitation in an iron-limited environment. Limnol Ocean 57(6): 1619-1633. doi: 10.4319/lo.2012.57.6.1619

Durkin CA, Van Mooy BAS, Dyhrman ST, Buesseler KO. 2016. Sinking phytoplankton associated with carbon flux in the Atlantic Ocean: Sinking phytoplankton and carbon flux. Limnol. Oceanogr. 61, 1172-1187. https://doi.org/10.1002/Ino.10253

Franck VM, Brzezinski MA, Coale KH, Nelson DM. 2000. Iron and silicic acid concentrations regulate Si uptake north and south of the Polar Frontal Zone in the Pacific Sector of the Southern Ocean. Deep Sea Res Part II Top Stud Oceanogr 47: 3315-3338.

Frölicher TL, Sarmiento JL, Paynter DJ, Dunne JP, Krasting JP vvinton M. 2015. Dominance of the Southern Ocean in Anthropogenic Carbon and Heat Uptake ' CIVIIP5 Models. J Clim 28(2): 862-886. doi: 10.1175/JCLI-D-14-00117.1

González H. 1992. Distribution and abundance if minipellets around the Antarctic peninsula. Implications for protistan feeding bet dvi ur. Mar Ecol Prog Ser 90: 223-236. doi: $10.3354 /$ meps090223

Hamm CE, Merkel R, Springer O, Jurko, P, Maier C, Prechtel K, Smetacek V. 2003. Architecture and material properties of diatom shells ?rovide effective mechanical protection. Nature 421(6925): 841843. doi: $10.1038 /$ nature01416

Henson, S., Le Moignt, F., Gi _ring, S., 2019. Drivers of Carbon Export Efficiency in the Global Ocean. Glob. Biogeochc $m$. Cycles 33, 891-903. https://doi.org/10.1029/2018GB006158

Hoban MA, Fryxell GA, Buck KR. 1980. Biddulphioid diatoms: Resting spores in antarctic Eucampia and Odontella. J Phycol 16(4): 591-602. doi: 10.1111/j.1529-8817.1980.tb03078.x

Hoffmann L, Peeken I, Lochte K. 2007. Effects of iron on the elemental stoichiometry during EIFEX and in the diatoms Fragilariopsis kerguelensis and Chaetoceros dichaeta. Biogeosciences 4(4): $569-$ 579.

Hoffmann L, Peeken I, Lochte K, Assmy P, Veldhuis M. 2006. Different reactions of Southern Ocean 
phytoplankton size classes to iron fertilization. Limnol Oceanogr 51(3): 1217-1229. doi: 10.4319/lo.2006.51.3.1217

Hutchins DA, Bruland KW. 1998. Iron-limited diatom growth and Si:N uptake ratios in a coastal upwelling regime. Nature 393(6685): 561-564. doi: 10.1038/31203

Jackson GA, Waite AM, Boyd PW. 2005. Role of algal aggregation in vertical carbon export during SOIREE and in other low biomass environments. Geophys Res Lett 32(13). doi: $10.1029 / 2005 G L 023180$

Jacques G. 1983. Some ecophysiological aspects of the Antarctic 'nyı plankton. Polar Biol 2(1): 2733. doi: $10.1007 /$ BF00258282

Jeandel C, Ruiz-Pino D, Gjata E, Poisson A, Brunet C, Char iauc E, Dehairs F, Delille D, Fiala M, Fravalo C, et al. 1998. KERFIX, a time-series station in the Soutt.ern C zean: a presentation. J Mar Syst 17(14): 555-569. doi: 10.1016/S0924-7963(98)00064-5

Kagami M, de Bruin A, Ibelings BW, Van Tonk E. 2007. Parasitic chytrids: their effects on phytoplankton communities and food-ı ab dynamics. Hydrobiologia 578(1): 113-129. doi: $10.1007 /$ s10750-006-0438-z

Kemp A, Villareal T. 2013. Hig' a 'tom production and export in stratified waters - A potential negative feedback to global waı. ni..g. Prog Ocean 119: 4-23. doi: 10.1016/j.pocean.2013.06.004

Kopczyńska EE, Fiala M, le ndel C. 1998. Annual and interannual variability in phytoplankton at a permanent station off Kerguelen Islands, Southern Ocean. Polar Biol 20(5): 342-351. doi: $10.1007 / \mathrm{s} 003000050312$

Kopczynska EE, Weber LH, El-Sayed SZ. 1986. Phytoplankton species composition and abundance in the Indian sector of the Antarctic Ocean. Polar Biol 6(3): 161-169. doi: 10.1007/BF00274879

Korb R, Whitehouse M, Atkinson A, Thorpe S. 2008. Magnitude and maintenance of the phytoplankton bloom at South Georgia: a naturally iron-replete environment. Mar Ecol Prog Ser 368: 75-91. doi: 10.3354/meps07525 
Korb R, Whitehouse M. 2004. Contrasting primary production regimes around South Georgia, Southern Ocean: large blooms versus high nutrient, low chlorophyll waters. Deep Sea Res Part Oceanogr Res Pap 51(5): 721-738. doi: 10.1016/j.dsr.2004.02.006

Kranzler CF, Krause JW, Brzezinski MA, Edwards BR, Biggs WP, Maniscalco M, McCrow JP, Van Mooy BAS, Bidle KD, Allen AE, et al. 2019. Silicon limitation facilitates virus infection and mortality of marine diatoms. Nat Microbiol, in press. doi: 10.1038/s41564-019-0502-x

Kuwata A, Hama T, Takahashi M. 1993. Ecophysiological characterization of two life forms, resting spores and resting cells, of a marine planktonic diatom, Chaetoceros "seudocurvisetus, formed under nutrient depletion. Mar Ecol Prog Ser 102(3): 245-255.

Kuwata A, Takahashi M. 1990. Life-form population resp unses of a marine planktonic diatom, Chaetoceros pseudocurvisetus, to oligotrophication in r.giol ally upwelled water. Mar Biol 107(3): 503-512. doi: 10.1007/BF01313435

Kuwata A, Takahashi M. 1999. Survival and $r$ scc 'ery of resting spores and resting cells of the marine planktonic diatom Chaetoceros pseudocurvis tus under fluctuating nitrate conditions. Mar Biol 134(3): 471-478. doi: 10.1007/s002270056_ 53

Kuwata A, Tsuda A. 2005. Selection .nd viability after ingestion of vegetative cells, resting spores and resting cells of the marine diat $m$, haetoceros pseudocurvisetus, by two copepods. J Exp Mar Biol Ecol 322(2): 143-151. doi: 10 li 1 /j.jembe.2005.02.013

Lam P, Bishop J. 2007. Hish jiomass, low export regimes in the Southern Ocean. Deep Sea Res Part II Top Stud Ocean 54(5-7): 601-638. doi: 10.1016/j.dsr2.2007.01.013

Lasbleiz M, Leblanc K, Armand L, Christaki U, Georges C, Obernosterer I, Quéguiner B. 2016. Composition of diatom communities and their contribution to plankton biomass in the naturally ironfertilized region of Kerguelen in the Southern Ocean. Fems Microbiol Ecol 92(11): fiw171. doi: 10.1093/femsec/fiw171

Lasbleiz M, Leblanc K, Blain S, Ras J, V C-B, Nunige S, Quéguiner B. 2014. Pigments, elemental composition ( $\mathrm{C}, \mathrm{N}, \mathrm{P}$, and $\mathrm{Si}$ ), and stoichiometry of particulate matter in the naturally iron fertilized region of Kerguelen in the Southern Ocean. Biogeosciences 11(20): 5931-5955. doi: 10.5194/bg-11- 
$5931-2014$

Leblanc K, Arístegui J, Armand L, Assmy P, Beker B, Bode A, Breton E, Cornet V, Gibson J, Gosselin MP, et al. 2012. A global diatom database - abundance, biovolume and biomass in the world ocean. Earth Syst Sci Data 4(1): 149-165. doi: 10.5194/essd-4-149-2012

Leblanc K, Hare CE, Boyd PW, Bruland KW, Sohst B, Pickmere S, Lohan MC, Buck K, Ellwood M, Hutchins DA. 2005. Fe and $\mathrm{Zn}$ effects on the Si cycle and diatom community structure in two contrasting high and low-silicate HNLC areas. Deep Sea Res Part Oceanogr Res Pap 52(10): 18421864. doi: $10.1016 / j . d s r .2005 .06 .005$

Leblanc K, Hutchins DA. 2005. New applications of a biogeni - sil"ca deposition fluorophore in the study of oceanic diatoms. Limnol Oceanogr Methods 3(10): <‘2-4/6. doi: 10.4319/lom.2005.3.462

Legendre P, Legendre L. 2012. Numerical Ecology. 3. Eng'. ed. rimsterdam: Elsevier. (Developments in environmental modelling; Vol. 24).

Lomas MW, Baer SE, Acton S, Krause JW. 2(19. Pumped Up by the Cold: Elemental Quotas and Stoichiometry of Cold-Water Diatoms. Frorı Mar Sci 6. doi: 10.3389/fmars.2019.00286

Maiti K, Charette MA, Buesseler KC, Kahru M. 2013. An inverse relationship between production and export efficiency in the Souther.' O 'an. Geophys Res Lett 40(8): 1557-1561. doi: 10.1002/grl.50219

Marchetti A, Cassar N. 孔าด Diatom elemental and morphological changes in response to iron limitation: a brief review w th potential paleoceanographic applications. Geobiology 7(4): 419-431. doi: $10.1111 / \mathrm{j} .1472-4669.2009 .00207 . x$

Martin J. 1990. Glacial-interglacial CO2 change: The Iron Hypothesis. Paleoceanography 5(1): 1-13. doi: 10.1029/PA005i001p00001

McNair HM, Brzezinski MA, Krause JW. 2015. Quantifying diatom silicification with the fluorescent dye, PDMPO. Limnol Oceanogr Methods 13(10): 587-599. doi: 10.1002/lom3.10049

McNair HM, Brzezinski MA, Krause JW. 2018. Diatom populations in an upwelling environment decrease silica content to avoid growth limitation. Environ Microbiol 20(11): 4184-4193. doi: 
$10.1111 / 1462-2920.14431$

McQuoid MR, Hobson LA. 1996. Diatom resting stages. J Phycol 32(6): 889-902. doi: 10.1111/j.00223646.1996.00889.x

Mongin M, Molina E, Trull TW. 2008. Seasonality and scale of the Kerguelen plateau phytoplankton bloom: A remote sensing and modeling analysis of the influence of natural iron fertilization in the Southern Ocean. Deep Sea Res Part II Top Stud Oceanogr 55(5-7): 880-892. doi: 10.1016/j.dsr2.2007.12.039

Morris PJ, Sanders R, Turnewitsch R, Thomalla S. 2007. 234Th-r erı ?d particulate organic carbon export from an island-induced phytoplankton bloom in the Sol int $n$ Ocean. Deep Sea Res Part II Top Stud Oceanogr 54(18-20): 2208-2232. doi: 10.1016/j.dsr2.2₹ ר7.vo.002

Mosseri J, Quéguiner B, Armand L, Cornet-Barthaux V. _.008. :mpact of iron on silicon utilization by diatoms in the Southern Ocean: A case study of $S_{1}, " v r /$ cle decoupling in a naturally iron-enriched area. Deep Sea Res Part II Top Stud Ocean 55, 5- ): ১:1-819. doi: 10.1016/j.dsr2.2007.12.003

Nelson DM, Brzezinski MA, Sigmon DE, Fra'ck VM. 2001. A seasonal progression of Si limitation in the Pacific sector of the Southern Ocear. [ eep Sea Res Part II Top Stud Oceanogr 48(19-20): 39733995. doi: 10.1016/S0967-0645(01, ^07ь-5

Nelson DM, Tréguer P. 1992 Ru'॰ sf silicon as a limiting nutrient to Antarctic diatoms: evidence from

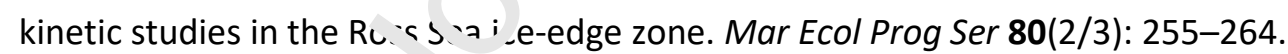

Oku O, Kamatani A. 1995. Resting spore formation and phosphorus composition of the marine diatom Chaetoceros pseudocurvisetus under various nutrient conditions. Mar Biol 123(2): 393-399. doi: $10.1007 / B F 00353630$

Paasche E. 1973. Silicon and the ecology of marine plankton diatoms. I. Thalassiosira pseudonana (Cyclotella nana) grown in a chemostat with silicate as limiting nutrient. Mar Biol 19(2): 117-126. doi: 10.1007/BF00353582

Park Y-H, Durand I, Kestenare E, Rougier G, Zhou M, d'Ovidio F, Cotté C, Lee J. 2014. Polar Front around the Kerguelen Islands: An up-to-date determination and associated circulation of 
surface/subsurface waters. J Geophys Res Oceans 119(10): 6575-6592. doi: 10.1002/2014JC010061

Park Y-H, Fuda J-L, Durand I, Naveira Garabato AC. 2008a. Internal tides and vertical mixing over the Kerguelen Plateau. Deep Sea Res Part II Top Stud Oceanogr 55(5-7): 582-593. doi: 10.1016/j.dsr2.2007.12.027

Park Y-H, Roquet F, Durand I, Fuda J-L. 2008b. Large-scale circulation over and around the Northern Kerguelen Plateau. Deep Sea Res Part II Top Stud Ocean 55(5-7): 566-581. doi: 10.1016/j.dsr2.2007.12.030

Pauthenet E, Roquet F, Madec G, Guinet C, Hindell M, McMahc n C.?, Harcourt R, Nerini D. 2018. Seasonal Meandering of the Polar Front Upstream of the Kergu' =le. Plateau. Geophys Res Lett 45(18): 9774-9781. doi: 10.1029/2018GL079614

Pelusi A, Margiotta F, Passarelli A, Ferrante MI, Riber^d'Ázalà M, Montresor M. 2020 May 27. Density-dependent mechanisms regulate spore forr, tir $n$ in the diatom Chaetoceros socialis. Limnol Oceanogr Lett, in press. doi: 10.1002/lol2.10.5s

Planchon F, Ballas D, Cavagna A-J, Bowit AR, Davies D, Trull T, Laurenceau-Cornec EC, Van Der Merwe P, Dehairs F. 2015. Carbon exp ort in the naturally iron-fertilized Kerguelen area of the Southern Ocean based on the ${ }^{234}$ i: approach. Biogeosciences 12(12): 3831-3848. doi: 10.5194/bg$12-3831-2015$

Pollard R, Salter I, Sanu 'rs? I ycas M, Moore C, Mills R, Statham P, Allen J, Baker A, Bakker D, et al. 2009. Southern Ocean def $p$-water carbon export enhanced by natural iron fertilization. Nature 457(7229): 577-580. doi: 10.1038/nature07716

Quéguiner B. 2001. Biogenic silica production in the Australian sector of the Subantarctic Zone of the Southern Ocean in late summer 1998. J Geophys Res Oceans 106(C12): 31627-31636. doi: $10.1029 / 2000 J C 000249$

Quéguiner B. 2013. Iron fertilization and the structure of planktonic communities in high nutrient regions of the Southern Ocean. Deep Sea Res Part II Top Stud Ocean 90: 43-54. doi: 10.1016/j.dsr2.2012.07.024 
Quéguiner B, Brzezinski MA. 2002. Biogenic silica production rates and particulate organic matter distribution in the Atlantic sector of the Southern Ocean during austral spring 1992. Deep Sea Res Part II Top Stud Oceanogr 49(9-10): 1765-1786. doi: 10.1016/S0967-0645(02)00011-5

Quéguiner B, Treguer P, Peeken I, Scharek R. 1997. Biogeochemical dynamics and the silicon cycle in the Atlantic sector of the Southern Ocean during austral spring 1992. Deep Sea Res Part II Top Stud Oceanogr 44(1-2): 69-89.

Ragueneau O, Savoye N, Amo Y, Cotten J, Tardiveau B, Leynaert A. 2005. A new method for the measurement of biogenic silica in suspended matter of coastal wate. - using Si:Al ratios to correct for the mineral interference. 25(5-6): 697-710. doi: 10.1016/j.csr.200 +.0=017

Ragueneau O, Tréguer P. 1994. Determination of biogenic - ilica in coastal waters: applicability and limits of the alkaline digestion method. Mar Ch.m .5(1-2): 43-51. doi: 10.1016/03044203(94)90090-6

Ras J, Claustre H, Uitz J. 2008. Spatial va' ab 'ity of phytoplankton pigment distributions in the Subtropical South Pacific Ocean: comparison hetween in situ and predicted data. Biogeosciences 5(2): 353-369. doi: 10.5194/bg-5-353-2008

Redfield AC. 1958. The biological $r_{\iota}$ ntrol of chemical factors in the environment. Am Sci 46(3): 205221.

Redfield AC, Ketchum ?H, Qir'iards FA. 1963. The influence of organisms on the composition of seawater. The Sea: $26-77 \wedge$ aw York.

Rembauville M, Salter I, Leblond N, Gueneugues A, Blain S. 2015a. Export fluxes in a naturally ironfertilized area of the Southern Ocean - Part 1: Seasonal dynamics of particulate organic carbon export from a moored sediment trap. Biogeosciences 12(11): 3153-3170. doi: 10.5194/bg-12-31532015

Rembauville M, Blain S, Armand L, Quéguiner B, Salter I. 2015b. Export fluxes in a naturally ironfertilized area of the Southern Ocean - Part 2: Importance of diatom resting spores and faecal pellets for export. Biogeosciences 12(11): 3171-3195. doi: 10.5194/bg-12-3171-2015 
Rembauville M, Blain S, Caparros J, Salter I. 2016. Particulate matter stoichiometry driven by microplankton community structure in summer in the Indian sector of the Southern Ocean. Limnol Ocean 61(4): 1301-1321. doi: 10.1002/Ino.10291

Rembauville M, Blain S, Manno C, Tarling G, Thompson A, Wolff G, Salter I. 2018. The role of diatom resting spores in pelagic-benthic coupling in the Southern Ocean. Biogeosciences 15(10): 3071-3084. doi: 10.5194/bg-15-3071-2018

Rembauville M, Manno C, Tarling GA, Blain S, Salter I. 2016. Strong contribution of diatom resting spores to deep-sea carbon transfer in naturally iron-fertilized wate, - downstream of South Georgia. Deep Sea Res Part Ocean Res Pap 115: 22-35. doi: 10.1016/j.dsr.2 16. 55.002

Sackett O, Armand L, Beardall J, Hill R, Doblin M, Connelly · Howes J, Stuart B, Ralph P, Heraud P. 2014. Taxon-specific responses of Southern Ocean diatı ms to Fe enrichment revealed by synchrotron radiation FTIR microspectroscopy. Biogeos lenct; 11(20): 5795-5808. doi: 10.5194/bg11-5795-2014

Sallée J-B, Matear RJ, Rintoul SR, Lenton A. :712. Localized subduction of anthropogenic carbon dioxide in the Southern Hemisphere oceans. Nat Geosci 5(8): 579-584. doi: 10.1038/ngeo1523

Salter I, Kemp AE, Moore MC, Lamp+t RS, Wolff GA, Holtvoeth J. 2012. Diatom resting spore ecology drives enhanced carbon export fro⿰氵 a naturally iron-fertilized bloom in the Southern Ocean. Global Biogeochem Cycles 26, GB1014, dr :10.1029/2010GB003977.

Sarmiento JL, Gruber N, Rr7 «zinski M, Dunne J. 2004. High-latitude controls of thermocline nutrients and low latitude biological productivity. Nature 427, 56-60. doi: 10.1038/nature02127

Sassenhagen, I., Irion, S., Jardillier, L., Moreira, D., Christaki, U., 2020. Protist Interactions and Community Structure During Early Autumn in the Kerguelen Region (Southern Ocean). Protist 171, 125709. https://doi.org/10.1016/j.protis.2019.125709

Savoye N, Trull TW, Jacquet SHM, Navez J, Dehairs F. 2008. 234Th-based export fluxes during a natural iron fertilization experiment in the Southern Ocean (KEOPS). Deep Sea Res Part II Top Stud Ocean 55(5-7): 841-855. doi: 10.1016/j.dsr2.2007.12.036 
Sherr E, Sherr B. 2007. Heterotrophic dinoflagellates: a significant component of microzooplankton biomass and major grazers of diatoms in the sea. Mar Ecol Prog Ser 352: 187-197. doi: $10.3354 /$ meps07161

Smayda TJ. 1978. From phytoplankton to biomass. In: Sournia A, editor. Monographs on oceanographic methodology 6. Phytoplankton manual. UNESCO, Paris, p 273-279.

Smetacek V, Assmy P, Henjes J. 2004. The role of grazing in structuring Southern Ocean pelagic ecosystems and biogeochemical cycles. Antarct Sci 16(4): 541-558. doi: $10.1017 /$ S0954102004002317

Sugie K, Kuma K. 2008. Resting spore formation in the marin $a_{1}$ tom Thalassiosira nordenskioeldii under iron- and nitrogen-limited conditions. I Pla.''ton Res 30(11): 1245-1255. doi: 10.1093/plankt/fbn080

Takahashi T, Sweeney C, Hales B, Chipman D, Nev 'ser ser T, Goddard J, lannuzzi R, Sutherland S. 2012. The Changing Carbon Cycle in the St utricn Ocean. Oceanography 25(3): 26-37. doi: 10.5670/oceanog.2012.71

Takeda S. 1998. Influence of iron avariz jil ty on nutrient consumption ratio of diatoms in oceanic waters. Nature 393(6687): 774-77\%. doi: 10.1038/31674

Tréguer P, Bowler C, Moriceau ? Jutkiewicz S, Gehlen M, Aumont O, Bittner L, Dugdale R, Finkel Z,

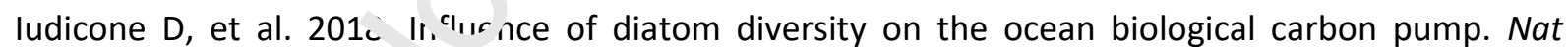
Geosci 11(1): 27-37. doi: 10 1038/s41561-017-0028-x

Twining BS, Baines SB, Fisher NS. 2004. Element stoichiometries of individual plankton cells collected during the Southern Ocean Iron Experiment (SOFeX). Limnol Oceanogr 49(6): 2115-2128. doi: 10.4319/lo.2004.49.6.2115

Uitz J, Claustre H, Griffiths F, Ras J, Garcia N, Sandroni V. 2009. A phytoplankton class-specific primary production model applied to the Kerguelen Islands region (Southern Ocean). Deep Sea Res Part Ocean Res Pap 56(4): 541-560. doi: 10.1016/j.dsr.2008.11.006

Utermöhl H. 1931. Neue Wege in der quantitativen Erfassung des Plankton.(Mit besonderer 
Berücksichtigung des Ultraplanktons.): Mit 4 Abbildungen im Text. SIL Proc 1922-2010 5(2): 567-596. doi: $10.1080 / 03680770.1931 .11898492$

Whitehouse MJ, Priddle J, Symon C. 1996. Seasonal and annual change in seawater temperature, salinity, nutrient and chlorophyll a distributions around South Georgia, South Atlantic. Deep Sea Res Part Oceanogr Res Pap 43(4): 425-443. doi: 10.1016/0967-0637(96)00020-9

Wilken S, Hoffmann B, Hersch N, Kirchgessner N, Dieluweit S, Rubner W, Hoffmann L, Merkel R, Peeken I. 2011. Diatom frustules show increased mechanical strength and altered valve morphology under iron limitation. Limnol Oceanogr 56(4): 1399-1410. doi: 10.4313/lo.2011.56.4.1399

Zhou M, Zhu Y, d'Ovidio F, Park Y-H, Durand I, Kestenare E sa vial V, Van-Beek P, Quéguiner B, Carlotti F, et al. 2014. Surface currents and upwelling in $\mathrm{Kc}_{\mathrm{c}}$ gueıen Plateau regions. Biogeosciences Discuss 11(5): 6845-6876. doi: 10.5194/bgd-11-6845-201 । 
The structure of diatom communities constrains biogeochemical properties in surface waters of the Southern Ocean (Kerguelen Plateau)

Augustin Lafond ${ }^{1}$, Karine Leblanc ${ }^{1}$, Justine Legras ${ }^{1}$, Véronique Cornet ${ }^{1}$, Bernard Quéguiner ${ }^{1}$

${ }^{1}$ Aix-Marseille University, Université de Toulon, CNRS, IRD, MIO, UM 110, 13288, Campus de Luminy, 163 avenue de Luminy, 13288 Marseille, France

Correspondence: augustin.lafond@gmail.com

Suppleı.`entary material 
Table S1. Range and mean (in parentheses when given together) values of linear measurements, biovolume, and carbon biomass of major diatom taxa observed during MOBYDICK. $\mathrm{N}=$ number of observations; $\mathrm{D}=$ diameter; $\mathrm{AA}=$ apical axis; $\mathrm{TA}=$ transapical axis; $\mathrm{PA}=$ pervalvar axis; $\mathrm{CV}=$ coefficient of variation. Shapes were used to estimate volume from linear dimensions: $\mathrm{RB}=$ rectangular box; $\mathrm{C}=$ cylinder $\mathrm{EC}=$ elliptic cylinder $; \mathrm{EC}+4 \mathrm{H}=$ elliptic cylinder +4 horns; $\mathrm{S}=$ spindle; $\mathrm{CU}=$ cuboid $; \mathrm{PP}=$ prism on parallelogram base.

\begin{tabular}{|c|c|c|c|c|c|c|c|c|c|}
\hline \multirow{2}{*}{$\begin{array}{l}\text { Species and genera } \\
\text { groupings }\end{array}$} & \multirow[t]{2}{*}{$\mathrm{N}$} & \multirow[b]{2}{*}{$\begin{array}{c}D \\
(\mu \mathrm{m})\end{array}$} & \multirow[b]{2}{*}{$\begin{array}{c}\mathrm{AA} \\
(\mu \mathrm{m})\end{array}$} & \multicolumn{6}{|c|}{ Shape } \\
\hline & & & & $\begin{array}{c}\mathrm{TA} \\
(\mu \mathrm{m})\end{array}$ & $\begin{array}{c}\text { PA } \\
(\mu \mathrm{m})\end{array}$ & & $\begin{array}{c}\text { Biovolume } \\
\left(\mu \mathrm{m}^{3}\right)\end{array}$ & $\begin{array}{l}\mathrm{CV} \\
(\%)\end{array}$ & $\begin{array}{l}\text { Cell carbon } \\
\left(\text { pg cell }^{-1}\right)\end{array}$ \\
\hline Actinocyclus octonarius & 32 & $41.4-122.7(57.3)$ & & & & C & 91364 & 132 & 2619 \\
\hline Actinocyclus / Thalassiosira spp. & 1332 & 7.1-49.6 (14.3) & & & $4-23.4\left(9 .^{2}\right.$ & C & 2865 & 237 & 189 \\
\hline Azpeitia tabularis & 25 & $34.4-82.1(48.3)$ & & & & C & 69309 & 83 & 2123 \\
\hline Chaetoceros atlanticum (chain) & 148 & & $7.1-29.9(17.4)$ & & (.5-. $7.7(: 5.1)$ & EC & 2874 & 62 & 189 \\
\hline Chaetoceros atlanticum, (sigmoïd) & 942 & & 7-31.5 (15.2) & $7.5-12.2(10.2)$ & 4. '-35.2 (10.9) & EC & 1489 & 67 & 115 \\
\hline Chaetoceros atlanticum (bulbosum) & 234 & & $8.3-24.1(15.3)$ & $9.8-19.2(13.1)$ & $6.8-19.3(12)$ & EC & 1933 & 51 & 140 \\
\hline Chaetoceros castracanaei & 71 & & $8.5-16.6(12.8)$ & $65-8$.... & $5.4-20.2(11.6)$ & EC & 1098 & 41 & 91 \\
\hline Chaetoceros criophilus & 19 & & $9.3-61.4\left(16.2^{\prime}\right.$ & & $9.4-74.5(16.9)$ & EC & 10378 & 338 & 501 \\
\hline Chaetoceros dichaeta & 100 & & $14.1-45 .{ }^{9}(23.5)$ & & $9.4-30.7(15.6)$ & EC & 4987 & 65 & 287 \\
\hline Chaetoceros cf neglectus & 130 & & $2.6-123(.8)$ & & $2.1-9.7(4.4)$ & EC & 92 & 98 & 14 \\
\hline Chaetoceros resting spores & 100 & & $4.2 \cdot 11^{\prime} .15 .4$ & & $3.3-7.4(4.6)$ & EC & 94 & 60 & 44 \\
\hline Chaetoceros sp. (small Hyalochaete) & 93 & & 5.4. 18.. (11.8) & $4.8-8.9(7)$ & & EC & 632 & 53 & 60 \\
\hline Corethron inerme & 1571 & $12.9-43(30 .)$. & r & & $33.3-197.4(98.5)$ & C & 62874 & 52 & 1972 \\
\hline Corethron pennatum (syn: C. criophilum) & 67 & $6-7 r \cap(j-9)$ & & & $16.4-434.5(166.5)$ & C & 316627 & 136 & 6736 \\
\hline Dactyliosolen antarctica & 79 & 14. '-71.7 (37.2) & & & $34.4-215.6(119.1)$ & C & 148697 & 67 & 3793 \\
\hline Eucampia antarctica (typical) & 263 & & $21.1-62.9(51.2)$ & 13.9-20.4 (17.3) & $17.8-41(29.2)$ & EC & 20384 & 25 & 838 \\
\hline Eucampia antarctica (H shape) & 216 & & $15.6-52.8(22.4)$ & $14.4-19.3(16.3)$ & $16.8-51.7(25.7)$ & $\mathrm{EC}+4 \mathrm{H}$ & 8702 & 73 & 439 \\
\hline Guinardia cylindrus & 316 & 6.6-29.1 (15.9) & & & $16.2-122.9(54.7)$ & C & 12429 & 76 & 575 \\
\hline Leptocylindrus danicus & 51 & $5.1-13.9(8.4)$ & & & $24.8-160.8(59.5)$ & c & 4083 & 118 & 247 \\
\hline Odontella weissflogii resting cell & 61 & & $24.2-43(31.8)$ & & $39.9-57.5(48.2)$ & EC & 25546 & 24 & 994 \\
\hline Odontella weissflogii resting spore & 11 & & $31.2-60.7(52.8)$ & & $22.5-49(45.2)$ & EC & 75156 & 46 & 2258 \\
\hline Proboscia alata & 181 & $8.9-45.8(20.9)$ & & & $238.3-1183(644.6)$ & C & 236232 & 67 & 5392 \\
\hline Proboscia inermis (winter form) & 149 & $6.8-25.1(11.2)$ & & & $26-1070(129)$ & C & 18354 & 192 & 773 \\
\hline Proboscia inermis & 56 & $8.4-35.7(18.8)$ & & & $180.6-909(522.6)$ & C & 189895 & 113 & 4567 \\
\hline
\end{tabular}




\section{Journal Pre-proof}

Rhizosolenia antennata/hebetata f. semispina

Rhizosolenia chunii

Rhizosolenia polydactyla f. polydactyla

Thalassiosira lentiginosa

Cylindrotheca closterium (robust)

Cylindrotheca closterium (thin)

Fragilariopsis kerguelensis

Fragilariopsis pseudonana

Fragilariopsis rhombica

Fragilariopsis rhombica/separanda

Membraneis sp.

Pseudo-nitzschia cf lineola

Pseudo-nitzschia cf heimii

Thalassionema nitzschioides

Thalassiothrix sp.

\section{8-38.3 (16.1)}

3.8-47.2 (16)

21.4-47.1 (38)

38.4-90.2 (59.6)

1027

302

1300

417

68

44

86

666

172

1096
221.7-1433.4 (749.7)

9.6-171.9 (34.8)

286.2-1433 (632.5)

4.8-10.5 (7.4)

5.7-41.7 (12.6)

4.6-12.9 (6.7)

$10.8-92.9(32.2)$

$1.5-13.5(6.5)$

10.4-35.5 (15.9)

$15.7-44.6$ (24)

38.1-310.4 (110.4)

22.1-150.7 (88.7)

63.6-150.8 (90.2)

9.5-131.3 (26.2)

744.4-1505.9 (110، ९)
0.9-6 (2.3)

1.4-7.3 (2.2)

$6.3-15(10.3)$

6.3-12.2 (9.3)

6.3-17.4 (8.3)

$6.5-100.8(36.6)$

2.1-6.4 (3.8)

$5-9,(0,7)$

(.1-5 + (4 )

3.418 .7 (9.8)

$\begin{array}{ccc}211809 & 165 & 4963 \\ 12393 & 175 & 574 \\ 754488 & 46 & 13032 \\ 25227 & 72 & 985 \\ 200 & 158 & 25 \\ 44 & 60 & 8 \\ 2111 & 78 & 149 \\ 39 & 73 & 7 \\ 614 & 61 & 58 \\ 1227 & 102 & 99 \\ 87413 & 125 & 2533 \\ 481 & 38 & 49 \\ 1329 & 46 & 105 \\ 695 & 217 & 64 \\ 139005 & 103 & 3603\end{array}$


Table S2. List of the taxa included in statistical analyses (i.e. hierarchical clustering and NMDS).

\begin{tabular}{|c|c|}
\hline Diatom taxa & Reference \\
\hline Actinocyclus Thalassiosira complex & Ehrenberg (1837) - Cleve (1873) \\
\hline Actinocyclus octonarius & Ehrenberg (1837) \\
\hline Asteromphalus spp. & Ehrenberg (1844) \\
\hline Azpeitia tabularis & Fryxell and Sims (1986) \\
\hline Centric & - \\
\hline Chaetoceros spp. & Ehrenberg (1844) \\
\hline Chaetoceros atlanticus & Cleve (1873) \\
\hline Chaetoceros castracanei & Karsten (1905) \\
\hline Chaetoceros convolutus & Castracane (1886) \\
\hline Chaetoceros criophylus & Castracane (1886 \\
\hline Chaetoceros decipiens & Cleve (1873) \\
\hline Chaetoceros dichaeta & Ehrenberg:' 844 I \\
\hline Chaetoceros neglectus & Karster $(19<5)$ \\
\hline Chaetoceros spp. resting spore & - \\
\hline Corethron inerme & K rc.el (1905) \\
\hline Corethron pennatum & ; Frunow) Ostenfeld (1909) \\
\hline Coscinodiscus spp. & Ehrenberg (1839) \\
\hline Coscinodiscus centralis & Ehrenberg (1839) \\
\hline Cylindrotheca closterium & (Ehrenberg) Reimann \& J.C.Lewin (1964) \\
\hline Dactyliosolen antarcticus & Castracane (1886) \\
\hline Dactyliosolen tenuijunctus & (Manguin) Hasle (1975) \\
\hline Eucampia antarctica & (Castracane) Mangin (1915) \\
\hline Fragilariopsis kerguelencic & (O'Meara) Hustedt (1952) \\
\hline Fragilariopsis pseu'?nต $\urcorner q$ & (Hasle) Hasle (1993) \\
\hline Fragilariopsis rhombica & (O'Meara) Hustedt (1952) \\
\hline Guinardia cylindrus & (Cleve) Hasle (1996) \\
\hline Haslea trompii & (Cleve) Simonsen (1974) \\
\hline Leptocylindrus danicus & Cleve (1889) \\
\hline Leptocylindrus mediterraneaus & (H.Peragallo) Hasle (1975) \\
\hline Membraneis spp. & Paddock (1988) \\
\hline Navicula spp. & Bory (1822) \\
\hline Odontella weiisflogii & (Grunow) Grunow (1884) \\
\hline Plagiotropis sp. & Pfitzer (1871) \\
\hline Pleurosigma spp. & Smith (1852) \\
\hline Proboscia alata & (Brightwell) Sundström (1986) \\
\hline
\end{tabular}


Proboscia inermis

Pseudo-nitzschia heimii

Pseudo-nitzschia lineola

Rhizosolenia spp.

Rhizosolenia antennata

Rhizosolenia chunii

Rhizosolenia curvata

Rhizosolenia polydactyla

Rhizosolenia simplex

Thalassionema nitzschioides

Thalassiosira lentiginosa

Thalassiosira tumida

Thalassiothrix antarctica
(F.Castracane) R.W.Jordan \& R.Ligowski (1991)

Manguin (1957)

(Cleve) Hasle (1993)

Brightwell (1858)

(Ehrenberg) N.E.Brown (1920)

Karsten (1905)

Zacharias (1905)

Castracane (1886)

Karsten (1905)

(Grunow) Mereschkowsky (1902)

(Janisch) Fryxell (19,“)

(Janisch) Hasle (1'/1)

Schimper and 'ia. teı (1905)

Pennate 


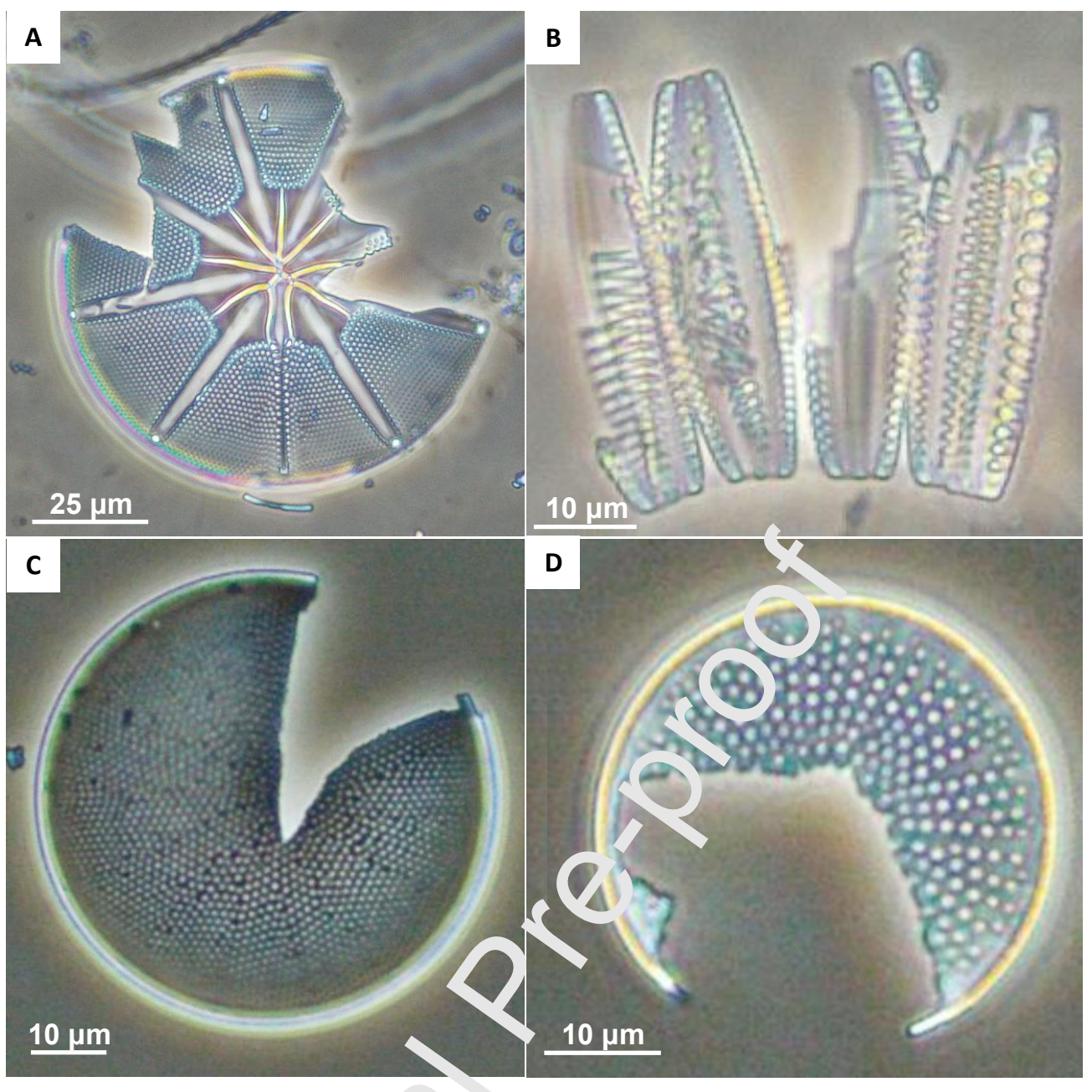

Figure S1. Selection of diatom images showing $r$ nc.ed frustules, which we considered as indicative of mesozooplankton grazing. (A) Asteromphalus hookeri, (B) Frag;'_- ${ }^{-10 k}$ : kerguelensis, (C) Thalassiosira lentiginosa, (D) Azpeitia tabularis. 

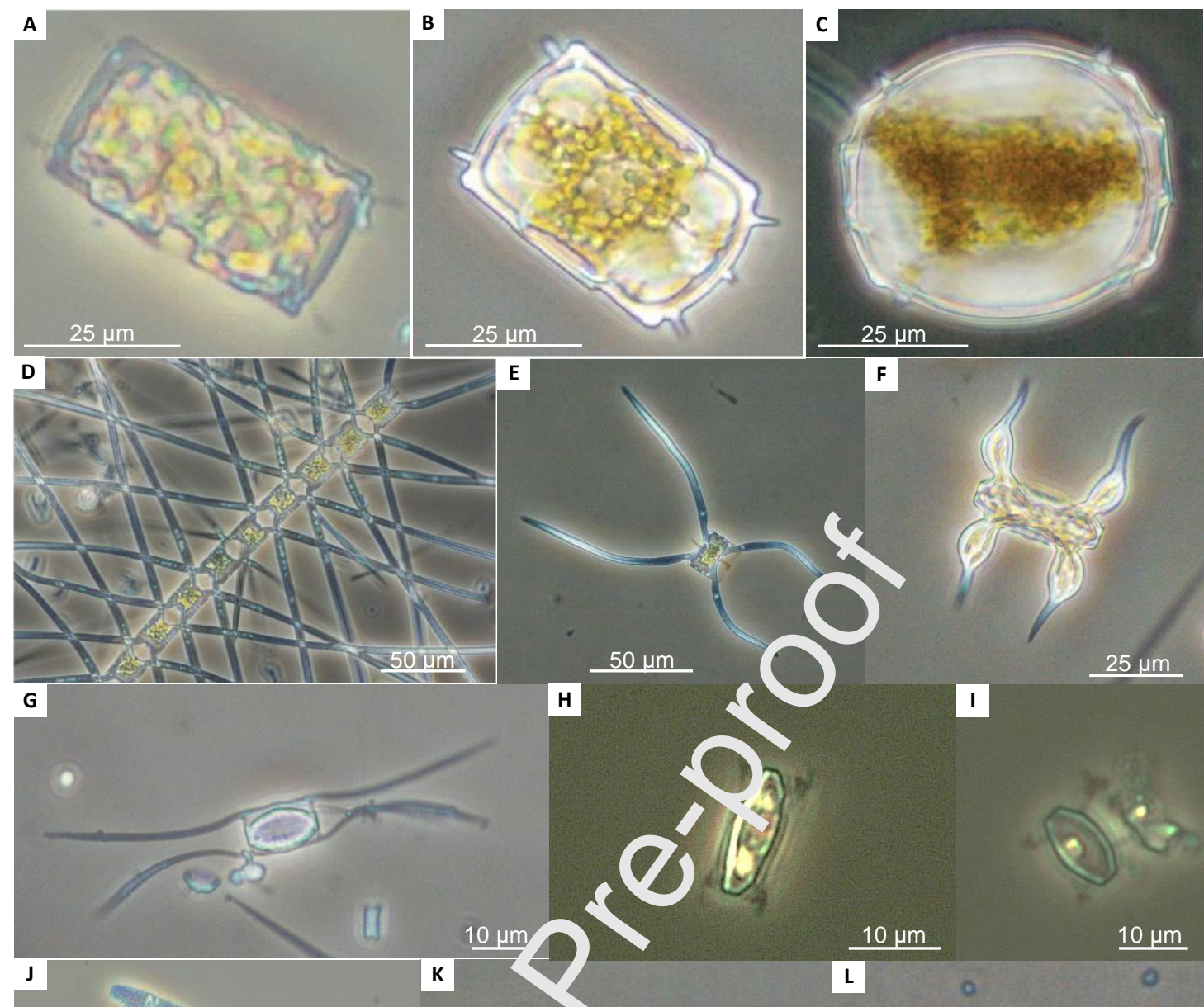

G
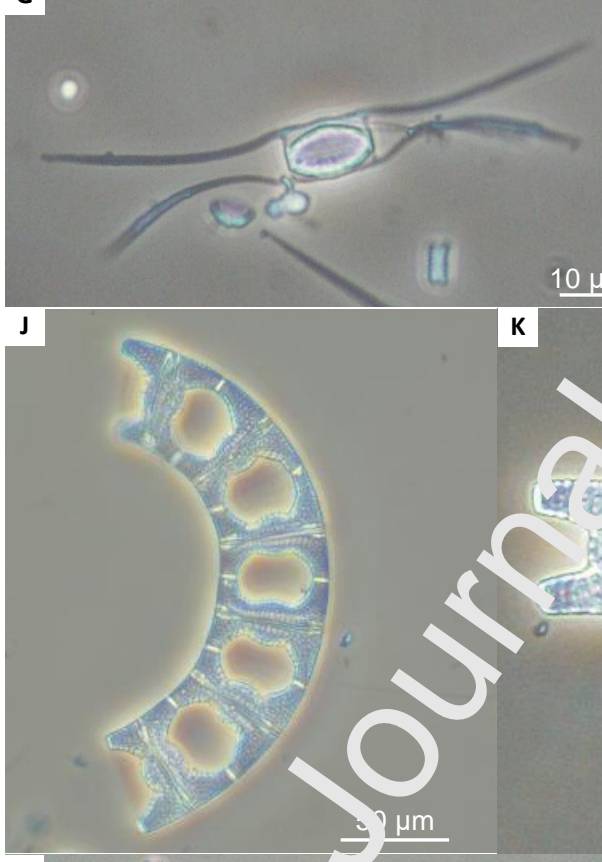

$\mathbf{K}$

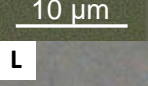

I
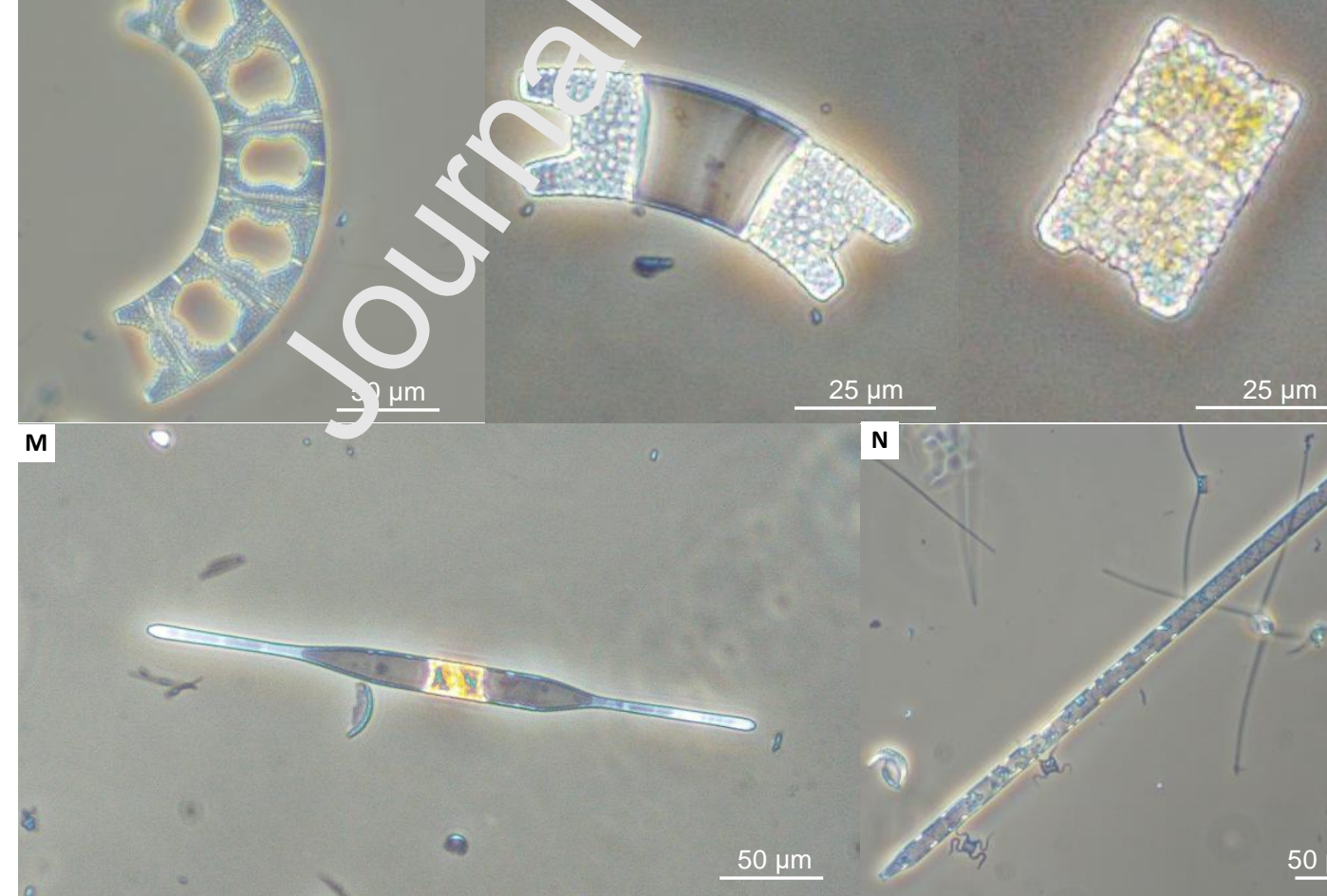

$10 \mu \mathrm{m}$

0
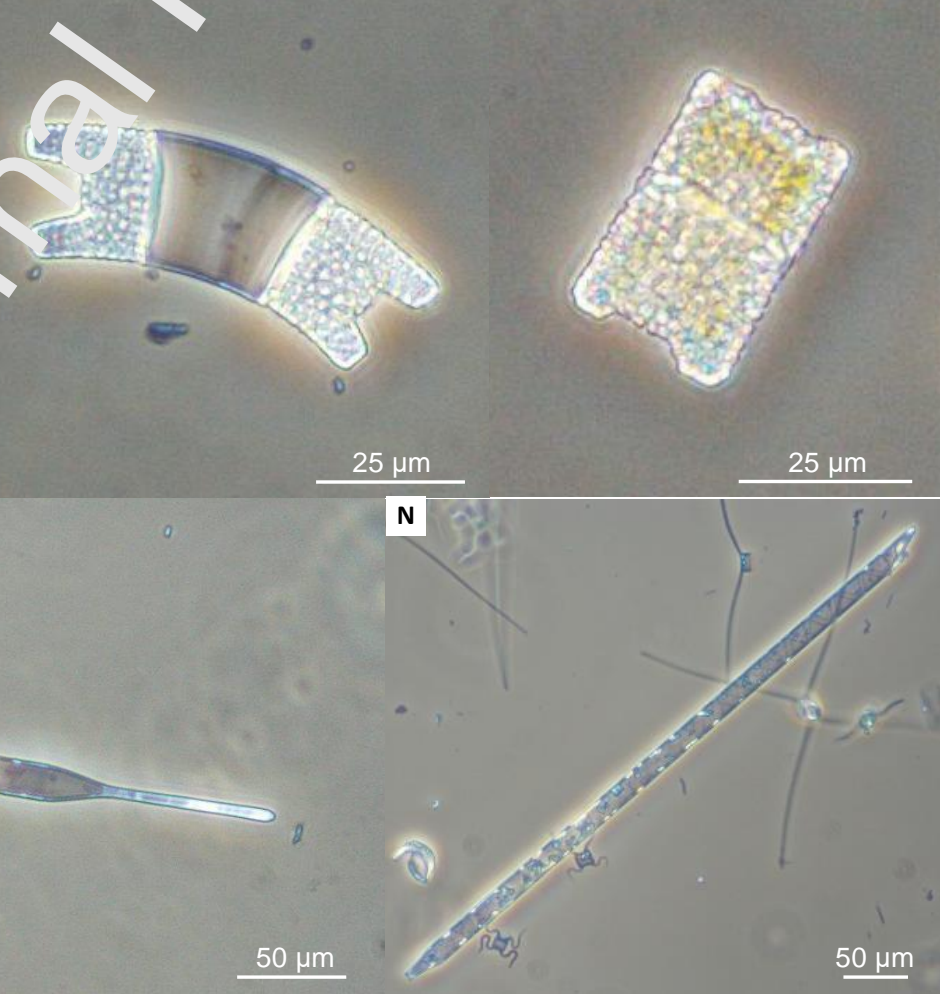

Figure S2. Selection of diatom images showing the variety of life stages and morphological forms within a same species. A) Odontella weissflogii vegetative cell, (B) Odontella weissflogii 'resting cell', (C) Odontella weissflogii 'resting spore', (D) Chaetoceros atlanticum 'colonial' form, (E) Chaetoceros atlanticum 'sigmoidal' form, (F) Chaetoceros atlanticum 'bulbosum' form, (G-I) Chaetoceros spp. resting spores, (J) Eucampia antarctica 'typical' form, (K) Eucampia antarctica 'H-shape' form, (L) Eucampia antarctica 'flat' form, (M) Proboscia inerme 'winter' form, (N) Proboscia inerme 'typical' form. 

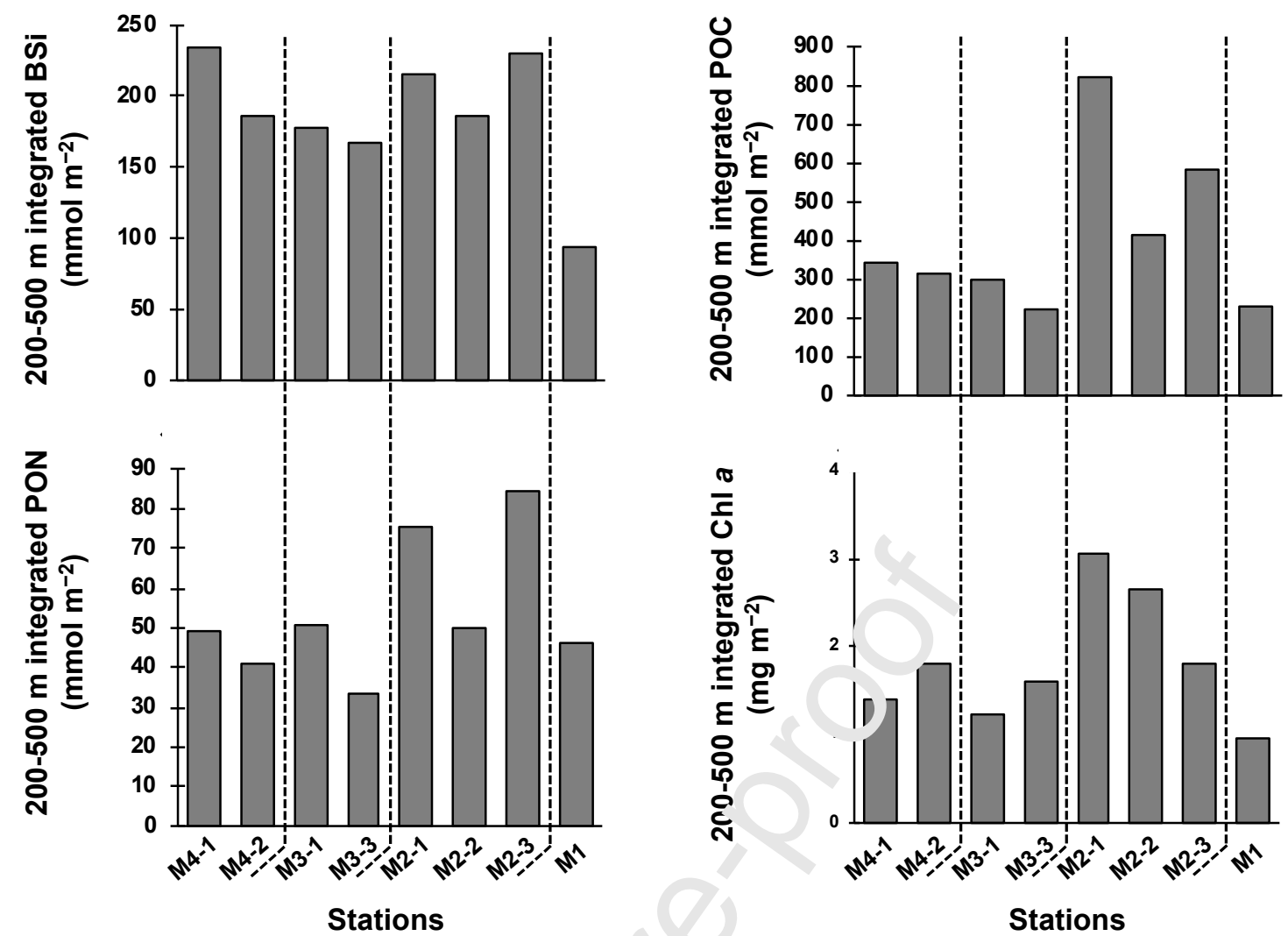

Figure S3. Integrated BSi, POC, PON, and Chl a concen 'atic is berween 200 and $500 \mathrm{~m}$ at the four stations. 

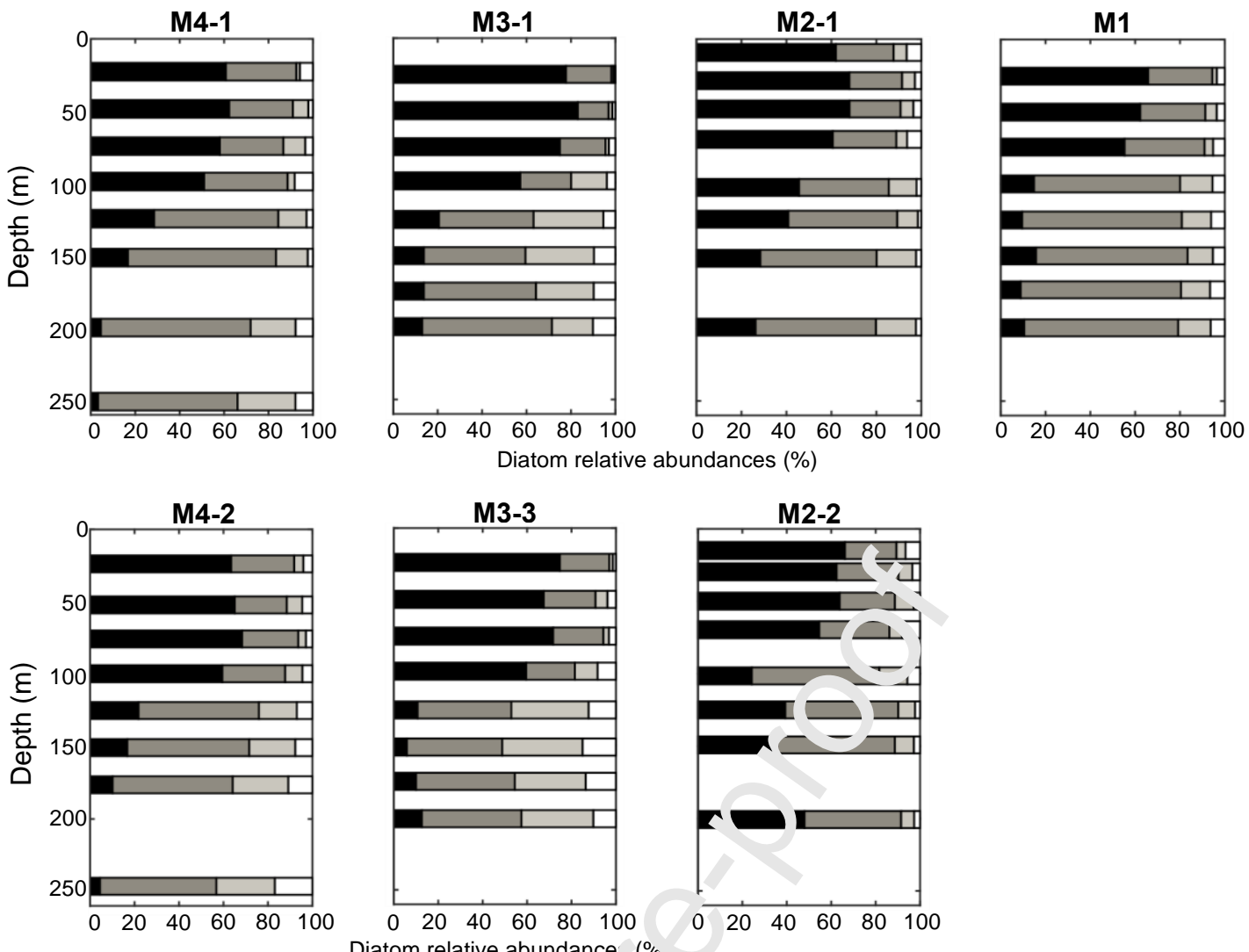

M3-3

M2-2
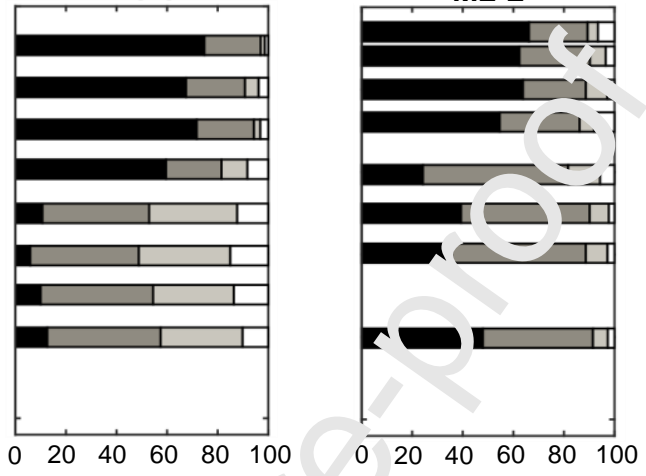
Diatom relative abundance: $\%$

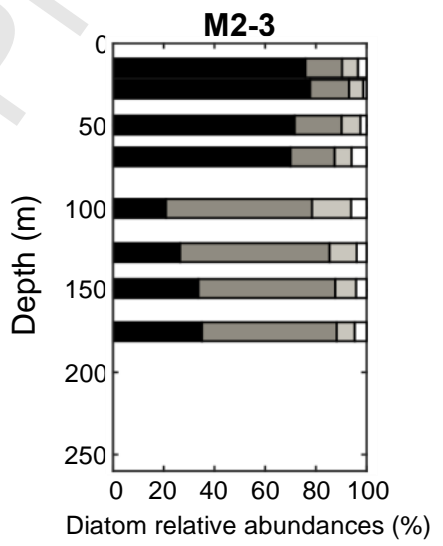

Figure S4. Diatom relative aburininces (in percent) to intact, empty, broken and crunched frustule at the four stations. 

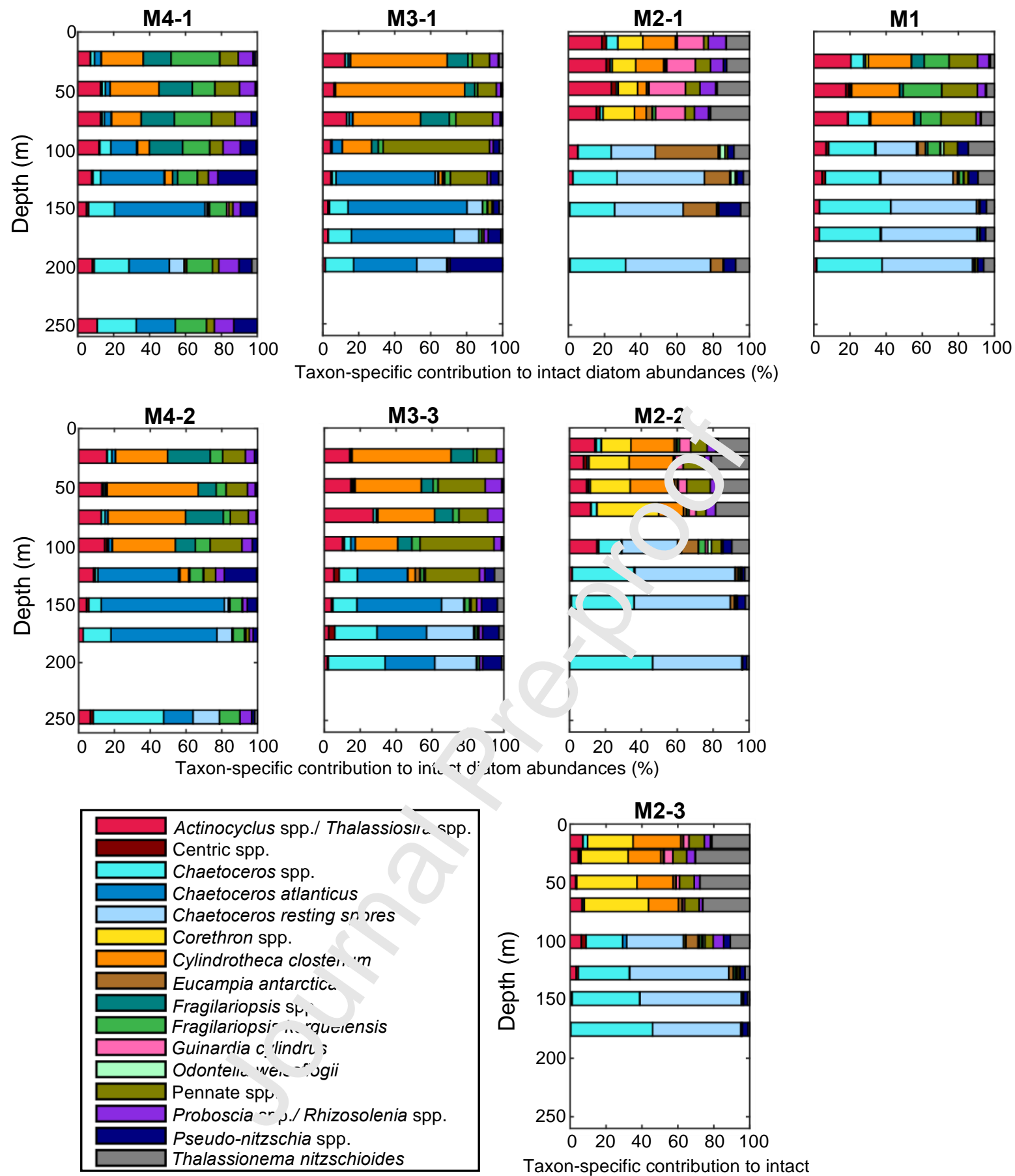

Taxon-specific contribution to intact diatom abundances (\%)

Figure S5. Taxon-specific contribution to intact diatom abundances at the four stations. 


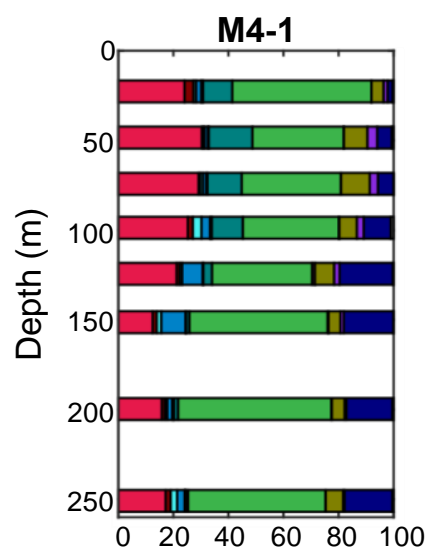

M3-1

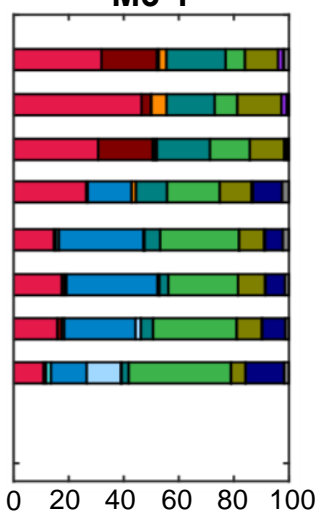

Taxon-specific contribution to empty diatom abundances (\%)
M2-1
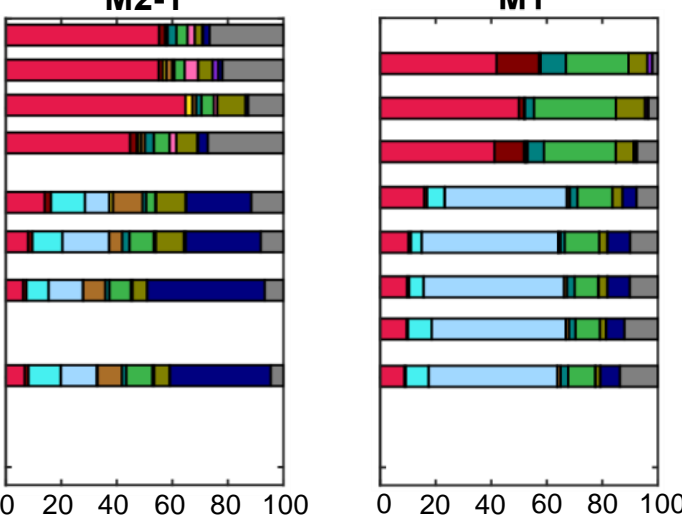

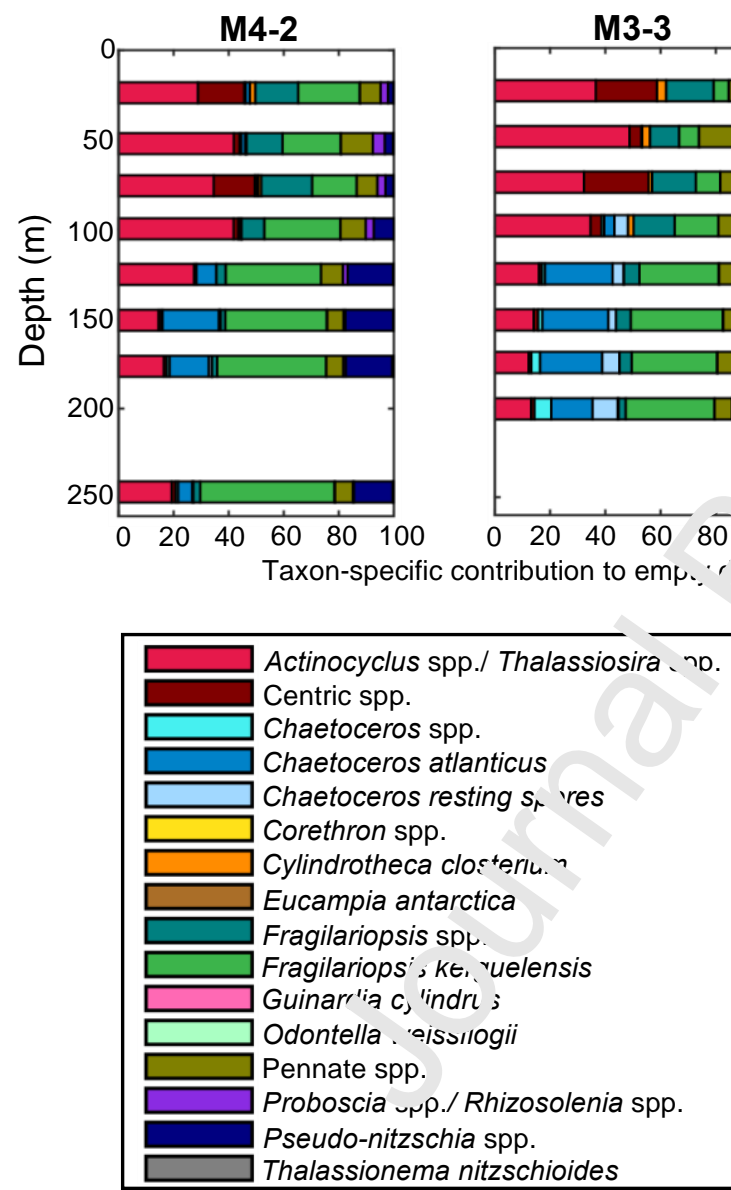

M2-2

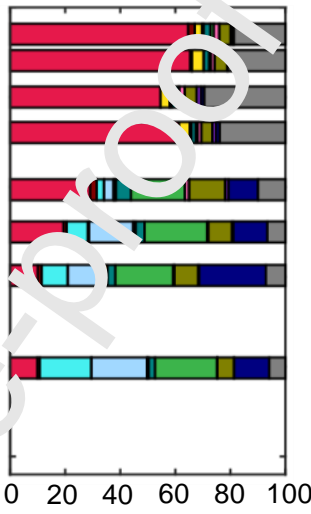

M2-3

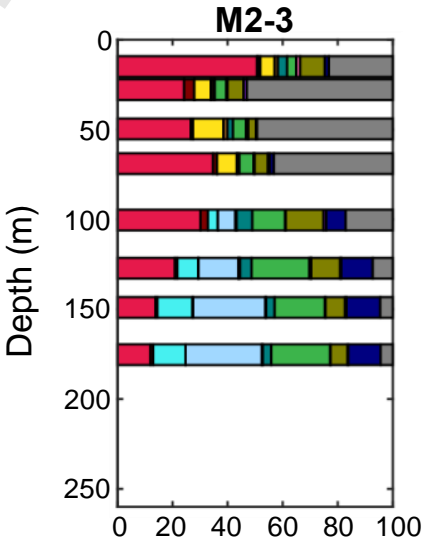

Taxon-specific contribution to empty diatom abundances (\%)

Figure S6. Taxon-specific contribution to empty diatom abundances at the four stations. 

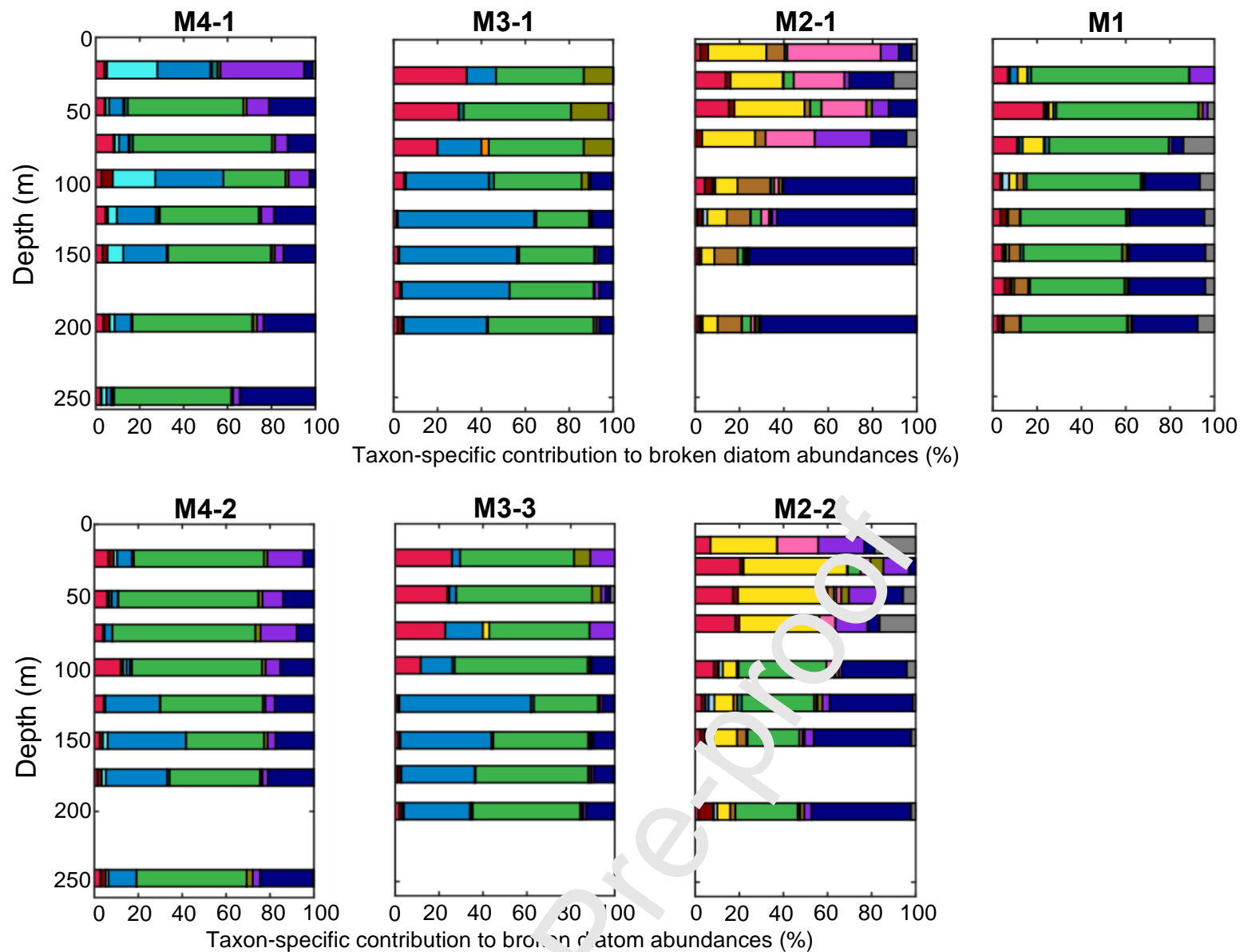

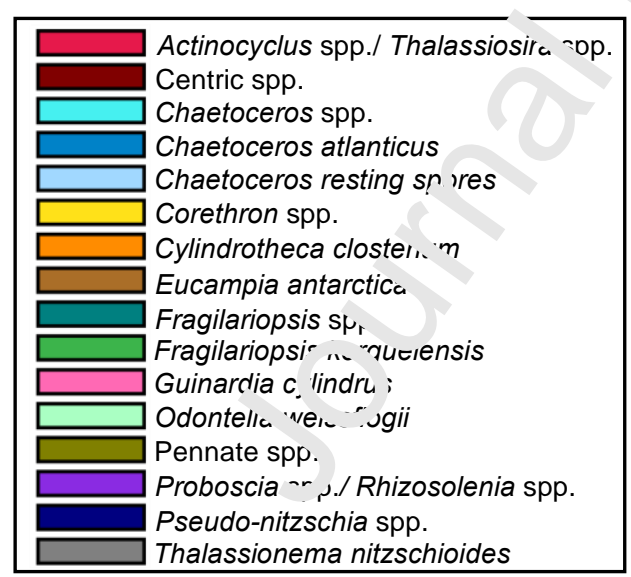

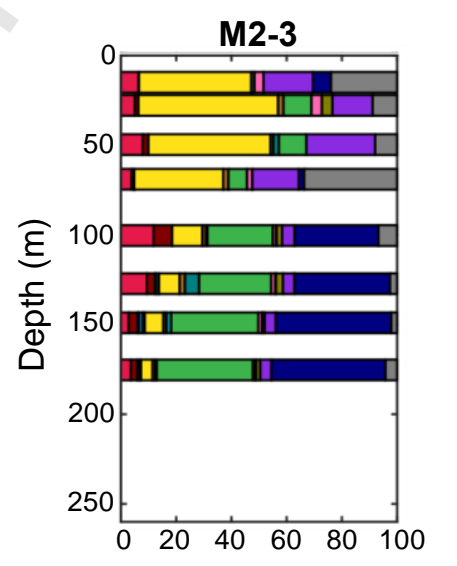

Taxon-specific contribution to broken diatom abundances (\%)

Figure S7. Taxon-specific contribution to broken diatom abundances at the four stations. 


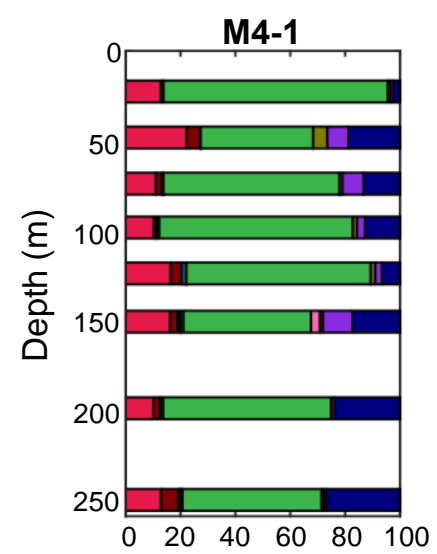

M3-1

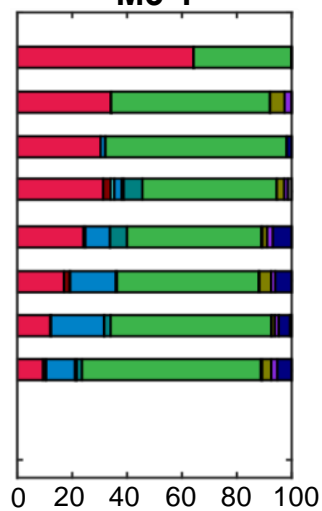

M2-1

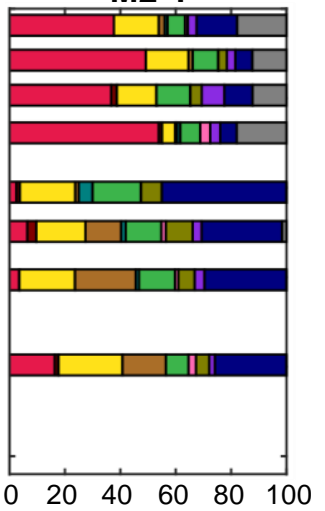

M1

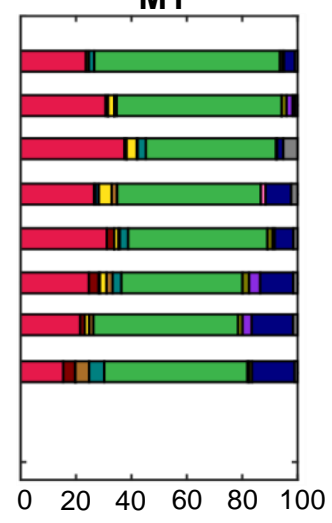

Taxon-specific contribution to crunched diatom abundances (\%)
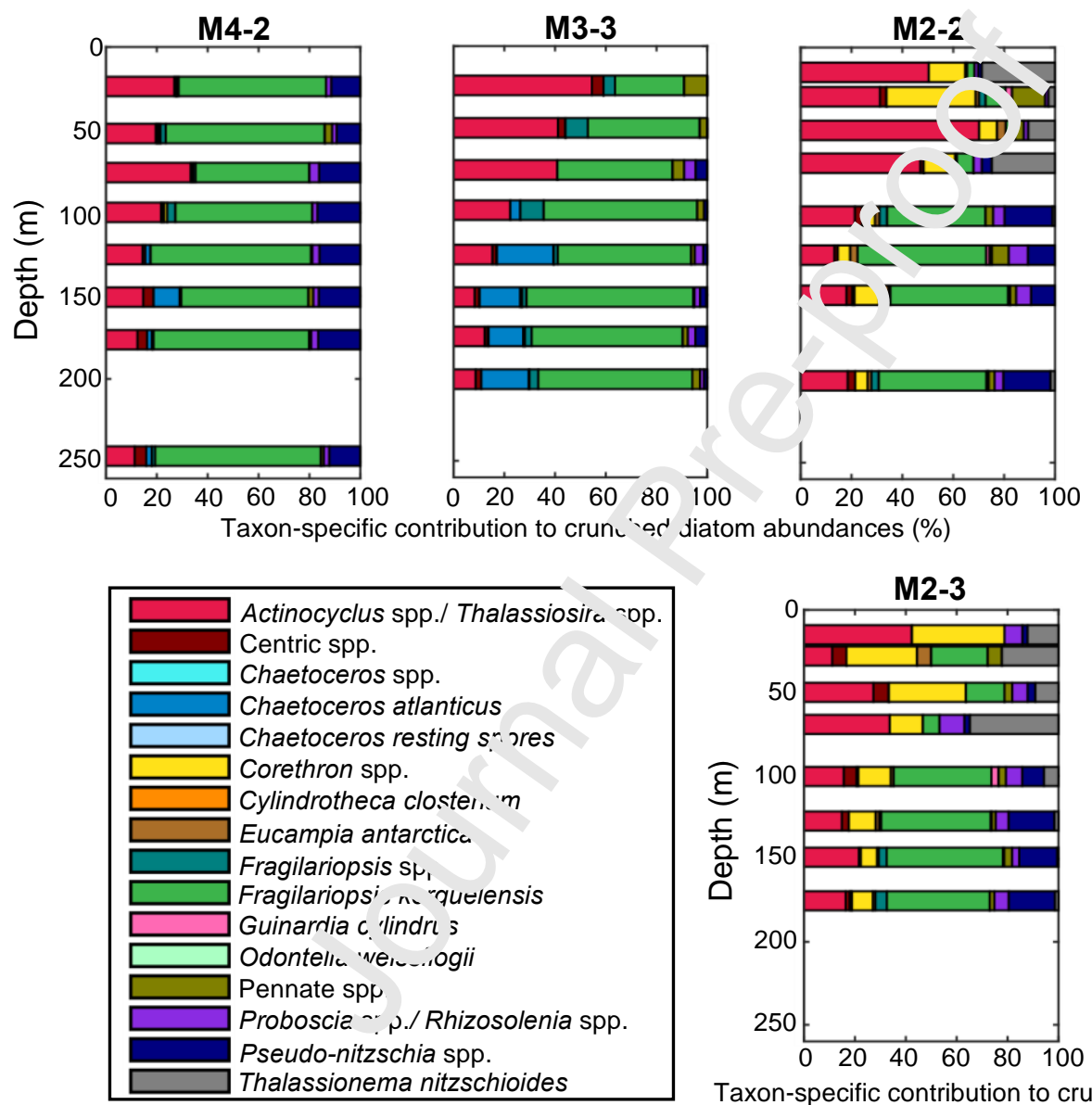

M2-3

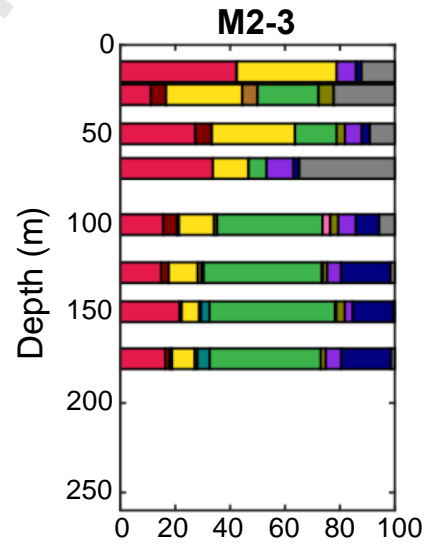

Taxon-specific contribution to crunched diatom abundances (\%)

Figure S8. Taxon-specific contribution to crunched diatom abundances at the four stations. 

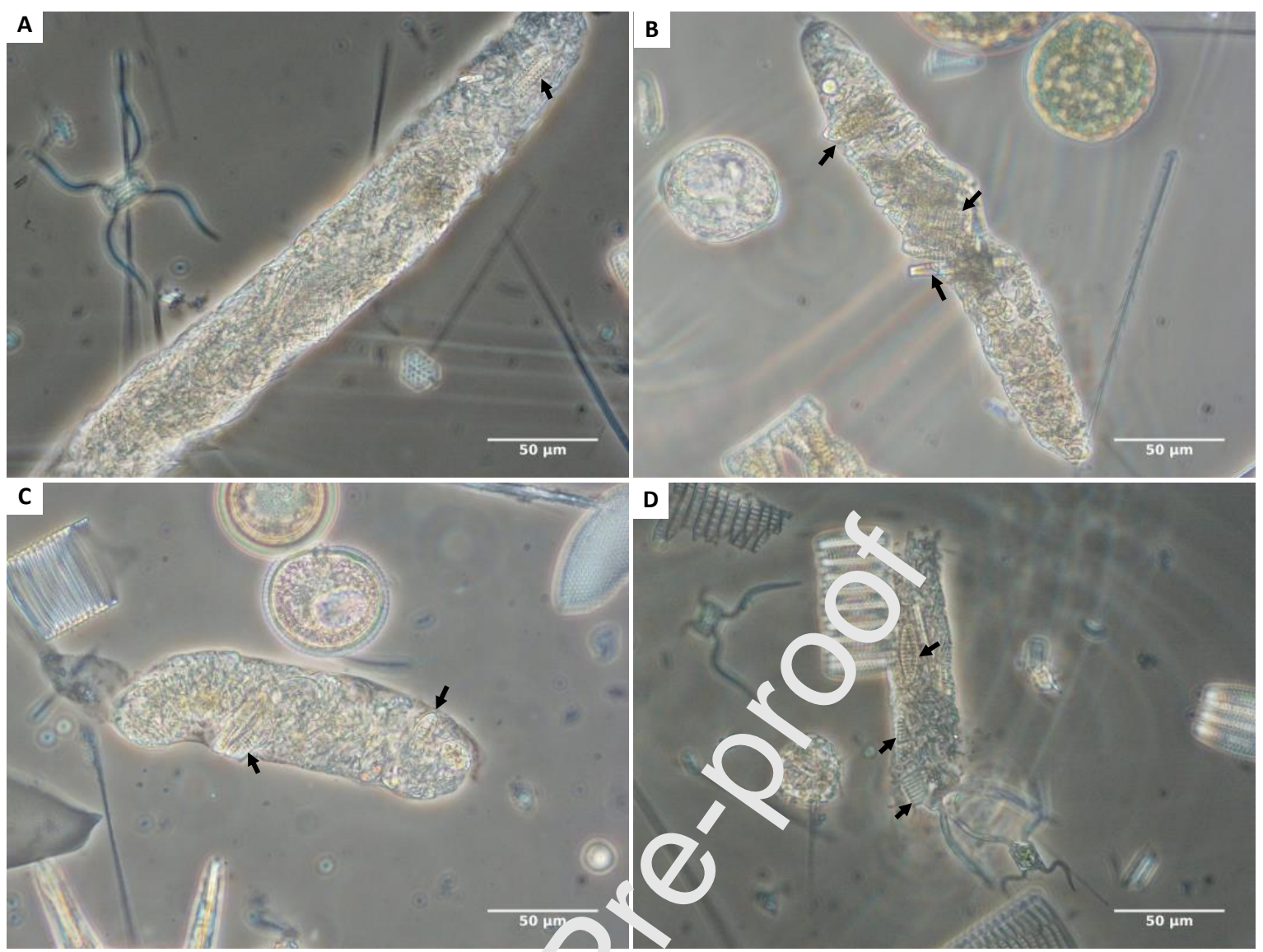

D

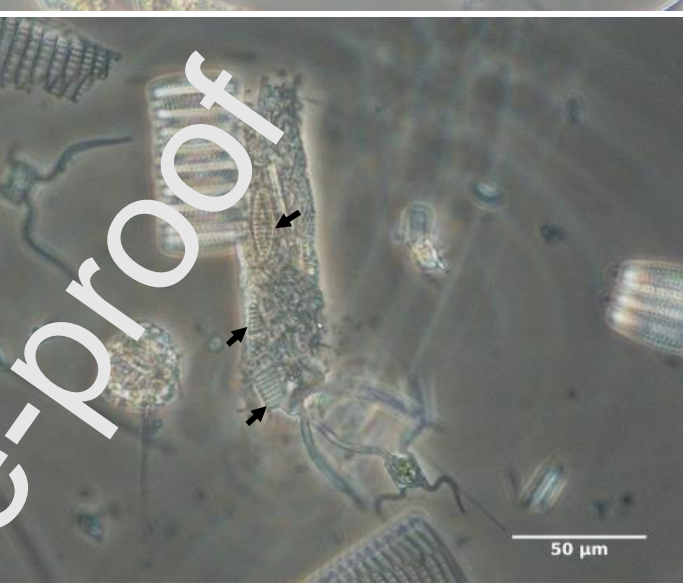

E
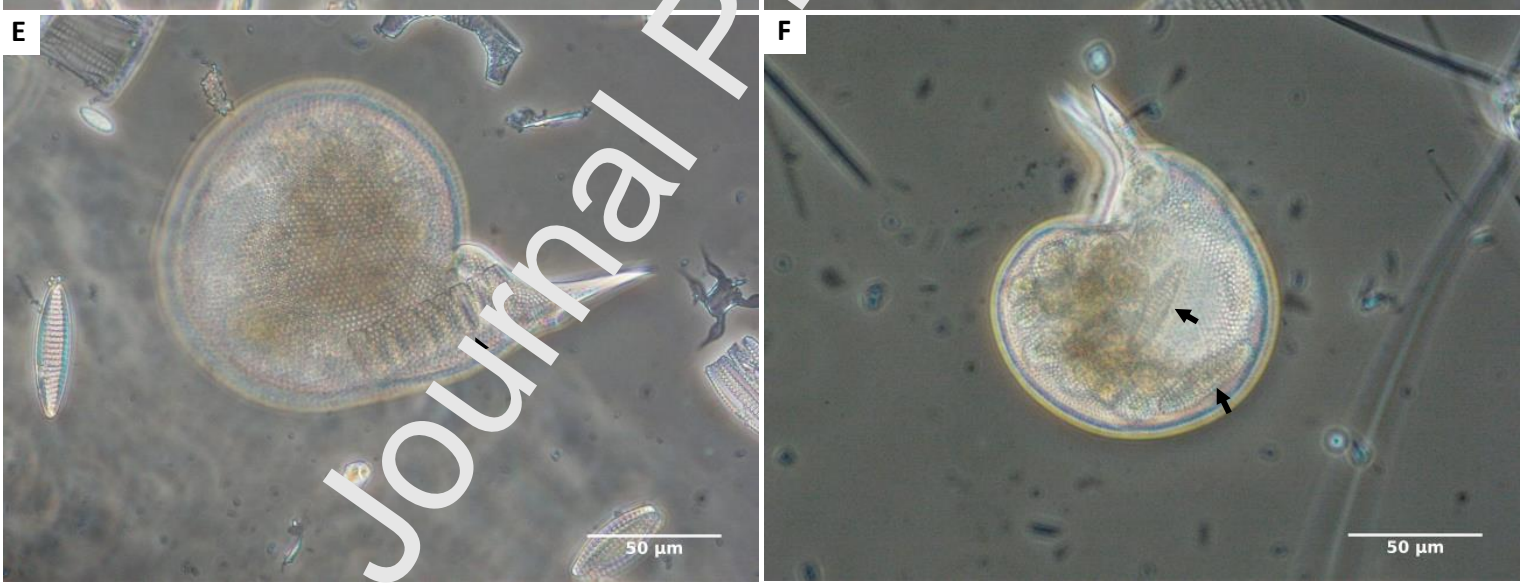

Figure S9. Selection of images evidencing grazing of the heavily silicified species Fagilariopsis kerguelensis by micro- and mesozooplankton, a diatom species traditionally considered as resistant to grazing. (A-D) Fecal pellets containing recognizable $F$. kerguelensis remains. Protocystis harstoni feeding on a whole chain (E) or solitary frustules (F) of $F$. kerguelensis. Black arrows indicate $F$. kerguelensis frustules. 
Highlights

- A distinct diatom community was growing despite low $\left[\mathrm{Si}(\mathrm{OH})_{4}\right]_{\text {above the Fe- }}$ fertilized plateau.

- A deep and inactive diatom community was systematically found within the pycnocline gradient.

- In HNLC waters, diatoms were more heavily silicified and exhibited higher Si:C ratios.

- In HNLC waters, detrital frustules of Fragilariopsis kerguelensis carried mostly Si below the ML.

- Above the plateau, Chaetoceros spp. vegetative cells and spores carried Si and C below the ML. 